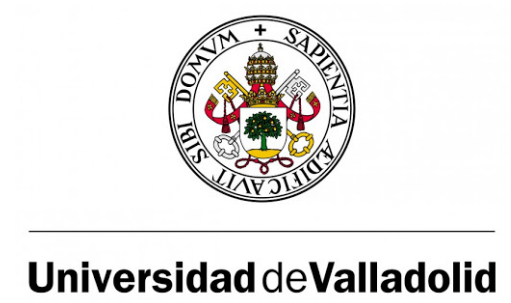

CSDUVa

PROGRAMA DE DOCTORADO EN FÍSICA

TESIS DOCTORAL:

\title{
DESARROLLO DE NUEVOS MÉTOdOS DE PROCESADO DE DATOS DE REDES FOTOMÉTRICAS PARA EL ANÁLISIS DE PROPIEDADES DEL AEROSOL ATMOSFÉRICO.
}

Presentada por Ramiro González Catón para optar al grado de Doctor por la Universidad de Valladolid

Dirigida por:

Dr. Carlos Toledano Olmeda

Dr. Roberto Román Diez 


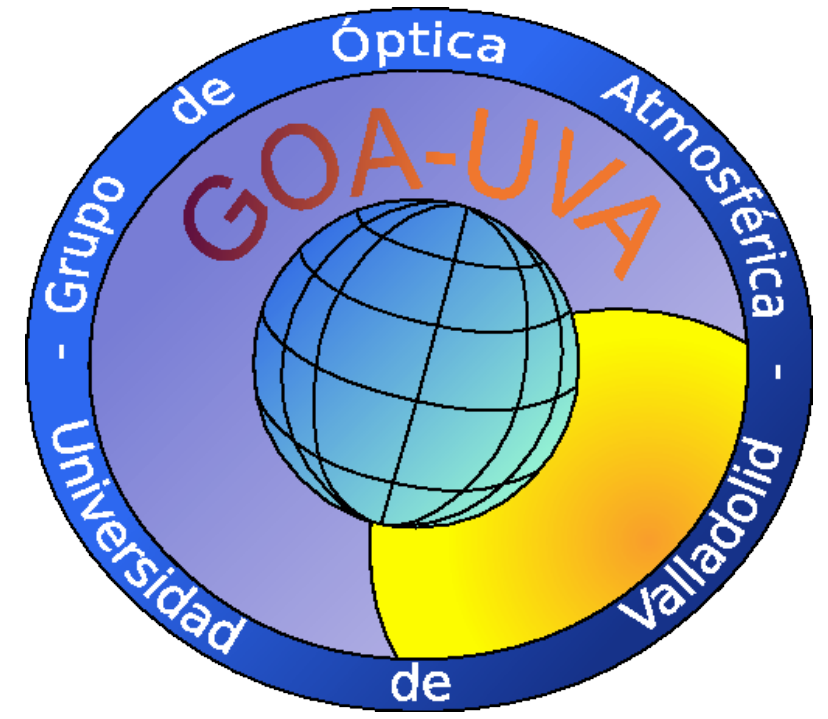

Este trabajo ha sido realizado en el

Grupo de Óptica Atmosférica de la Universidad de Valladolid 


\section{Compendio de publicaciones}

\section{- Publicación 1}

Referencia: González, R., Toledano, C., Román, R., Fuertes, D., Berjón, A., Mateos, D., Guirado-Fuentes, C., Velasco-Merino, C., Antuña-Sánchez, J. C., Calle, A., Cachorro, V. E., and de Frutos, Á. M.: Daytime and nighttime aerosol optical depth implementation in CÆLIS, Geosci. Instrum. Method. Data Syst., 9, 417-433, https://doi.org/10.5194/gi-9417-2020, in press, 2020.

Índice de impacto: 1.182 (2019), 1.437 (5 años), Categorías:

- Geosciences, Multidisciplinary: 164 de 200 (Q4)

- Meteorology \& Atmospheric Sciences: 83 de 93 (Q4)

\section{- Publicación 2}

Referencia: Román, R., González, R., Toledano, C., Barreto, Á., PérezRamírez, D., Benavent-Oltra, J. A., Olmo, F. J., Cachorro, V. E., AladosArboledas, L., and de Frutos, Á. M.: Correction of a lunar-irradiance model for aerosol optical depth retrieval and comparison with a star photometer, Atmos. Meas. Tech., https: / / amt.copernicus.org/artic les/13/6293/2020/, in press, 2020.

Índice de impacto: 3.668 (2019), 3.707 (5 años), Categorías:

- Meteorology \& Atmospheric Sciences: 27 de 93 (Q2)

\section{- Publicación 2}

Referencia: González, R., Toledano, C., Román, R.,Mateos, D., Asmi, E., Rodriguez, Lau, I. C., E., Ferrara, J., D`Elia, R., Antuña-Sánchez, J. C., Cachorro, V. E., Calle, A., de Frutos, A. M.: Characterization of stratospheric smoke particles over the Antarctica by remote sensing instruments, http s://doi.org/10.3390/rs12223769, Remote Sensing, acepted, 2020.

Índice de impacto: 4.509 (2019), 5.001 (5 años), Categorías:

- Remote Sensing 9 de $30(\mathrm{Q} 2)$ 

Muchas gracias a ti, por encima de todos, en especial a ti. El simple hecho de haber llegado a esta página me hace estarte agradecido. Bien está intentar tenerte amigo. 



\section{Índice general}

1 Introducción 1

1.1 Los aerosoles atmosféricos . . . . . . . . . . . . . . . 1

1.2 Técnicas de medida $\ldots \ldots \ldots \ldots \ldots \ldots \ldots \ldots \ldots$

1.3 Objetivos ..................... 11

1.4 Estructura de la tesis $\ldots \ldots \ldots \ldots \ldots \ldots \ldots$

2 Instrumentación y datos 13

2.1 Redes de medida . . . . . . . . . . . . . . . . . . . . . 13

2.1 .1 AERONET . . . . . . . . . . . . . . . . . . . . . . . 14

2.1.2 GOA Calibration Facillity $\ldots \ldots \ldots \ldots$

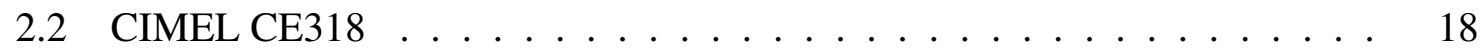

2.2.1 Familias de los fotómetros CIMEL . . . . . . . . . . . . . 19

2.2 .2 Tipos de medidas . . . . . . . . . . . . . . 20

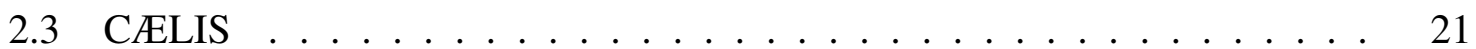

3 Resultados 27

3.1 Artículo 1: Daytime and nighttime aerosol optical depth implementation in

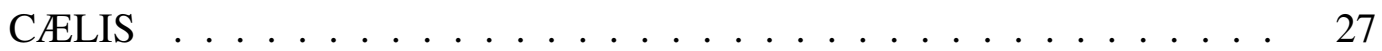

3.1 .1 Resumen y comentarios . . . . . . . . . . . . . . . 27 27

3.1.2 Daytime and nighttime aerosol optical depth implementation in CÆLIS 28

3.1.2.1 Introduction . . . . . . . . . . . . . . . . 29

3.1.2.2 General framework for AOD calculation . . . . . . . 31

3.1.2.2.1 CÆLIS database structure for AOD . . . . . 34

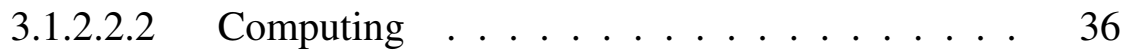

3.1.2.2.3 Ancillary data . . . . . . . . . . . 36

3.1.2.3 Direct Sun algorithm . . . . . . . . . . . . . . . 40

3.1.2.3.1 Aerosol optical depth . . . . . . . . . 40 
3.1.2.3.2 Ångström exponent \& precipitable water vapor 41

3.1.2.4 Direct Moon algorithm for AOD . . . . . . . . . 42

3.1.2.5 Cloud screening ................. 43

3.1.2.6 Validation of the AOD algorithm ......... 45

3.1.2.6.1 Data set for validation . . . . . . . . . 46

3.1.2.6.2 Daytime AOD validation ......... 46

3.1.2.6.3 Nighttime AOD evaluation ......... . . 49

3.1.2.6.4 Cloud screening validation ........ 50 50

3.1.2.7 Conclusions ................. 55 53

3.2 Artículo 2: Correction of a lunar-irradiance model for aerosol optical depth retrieval and comparison with a star photometer . . . . . . . . 56

3.2.1 Resumen y comentarios ................ 56

3.2.2 Correction of a lunar-irradiance model for aerosol optical depth retrieval and comparison with a star photometer . . . . . . . 57

3.2.2.1 Introduction . . . . . . . . . . . . . 58

3.2.2.2 Sites, Instrumentation and data . . . . . . . . 60 60

3.2.2.2.1 Sites . . . . . . . . . . . . 60

3.2.2.2.2 Instrumentation . . . . . . . . . . 62 62

3.2.2.2.3 Data management . . . . . . . . . . 63

3.2.2.3 AOD from Moon observations . . . . . . . . . . 64

3.2.2.3.1 Extraterrestrial Lunar Irradiance . . . . . . . . 64

3.2.2.3.2 Gain Calibration Method ........... 66

3.2.2.3.3 RIMO Correction Factor . . . . . . . . . 67 67

3.2.2.4 Moon vs star photometer . . . . . . . . . 73

3.2.2.5 Conclusions .................. 78

3.3 Artículo 3: Characterization of stratospheric smoke particles over the Antarctica by remote sensing instruments . . . . . . . . . . . . 83

3.3.1 Resumen y comentarios ............... 83

3.3.2 Characterization of stratospheric smoke particles over the Antarctica by remote sensing instruments . . . . . . . . . . . 84

3.3.2.1 Introduction . . . . . . . . . . . . . 85

3.3.2.2 Sites and instrumentation ............ 87

3.3.2.2.1 Measurement stations . . . . . . . . . 87

3.3.2.2.2 Instruments and data . . . . . . . . 88

3.3.2.3 Smoke event detection over Marambio . . . . . . . . . 90

3.3.2.4 Aerosol properties . . . . . . . . . . . . . . . 94 
3.3.2.5 Conclusions . . . . . . . . . . . . . 99

3.3.2.6 Acknowledgments . . . . . . . . . . . . . . . 101

4 Conclusiones y líneas futuras

Bibliografía

Índice de figuras

129

Índice de tablas

133 



\section{Resumen}

Se define como aerosol atmosférico a aquellas partículas que se encuentran suspendidas en la atmósfera en estado sólido o líquido. El estudio y análisis de los aerosoles son de vital importancia debido a que estos afectan al clima, a la actividad humana y a la salud de las personas. Distintas redes operan de forma rutinaria y con un grado mayor o menor de automatización con el objetivo de obtener medidas y productos de aerosoles para su posterior análisis. Las medidas ópticas o de detección remota, como las que proporcionan los fotómetros desde tierra y muchos sensores de satélite, basan su funcionamiento en la interacción de la luz con los aerosoles. Uno de los principales productos de estas redes es el espesor óptico de aerosoles (AOD del inglés Aerosol Optical Depth). Normalmente se obtiene el AOD midiendo con un fotómetro la irradiancia directa del Sol que llega a la superficie terrestre, ya que la cantidad de irradiancia directa solar extinguida durante su paso por la atmósfera terrestre depende del AOD a través de la ley de BeerBouguer-Lambert. El AOD está relacionado con la cantidad de aerosoles presentes en la columna atmosférica, y su variación espectral ligada al tamaño predominante de las partículas. Recientes avances y mejoras en los instrumentos de medida fotométrica han permitido adaptar las medidas directas al Sol también a la Luna, pudiendo obtener valores de AOD también durante la noche. Esto permite que en aquellas zonas con largos periodos nocturnos, principalmente en las zonas polares, se pueda de igual manera obtener información relacionada con los aerosoles. Esto ayuda a rellenar huecos muy relevantes en las series de datos obtenidas en estas zonas, que hasta ahora contaban tan solo con fotometría solar.

En este trabajo se aborda el análisis de las propiedades del aerosol atmosférico a través de la creación y mejora de nuevos procesados y productos. En concreto se presenta el desarrollo de nuevos métodos para el cálculo operacional del AOD en una red de instrumentos, tanto para el día como para la noche. En primer lugar, se ha desarrollado el cálculo del AOD durante el día describiendo paso a paso su proceso y datos utilizados. En una segunda instancia se ha adaptado este cálculo a la noche, describiendo de igual manera los modelos utilizados y desarrollando una nueva corrección sobre estos, la cual se propone para la mejora en el cálculo del AOD por la noche. Los productos obtenidos mediante ambos métodos se han contrastado con series de datos independientes y de referencia, que nos ha permitido asegurar la calidad del algoritmo.

Finalmente, la puesta en producción de ambos productos en el sistema CÆLIS ha permitido detectar un evento de aerosoles extremadamente anómalo en una de las estaciones que el Grupo de Óptica Atmosférica de la Universidad de Valladolid opera en la estación de Marambio, en la Antártida. Con la ayuda de otras medidas complementarias y algunos modelos atmosféricos, se ha descubierto que los aerosoles procedían de la quema de biomasa generada por incendios localizados en el Este de Australia a finales de 2019. La detección de este evento pone de manifiesto la importancia y el valor de disponer de medidas rutinarias, procesamientos automatizados y productos de calidad que permitan analizar las propiedades del aerosol atmosférico. 



\begin{abstract}
Atmospheric aerosol is defined as each particles that are in the atmosphere in solid or liquid state. The study and analysis of aerosols are of vital importance because aerosols affect the climate, human activity and the health of people. Different networks operate routinely and with a greater or lesser degree of automation in order to obtain measurements of aerosol products for subsequent analysis. Optical or remote sensing measurements, such as those provided by groundbased photometers and many satellite sensors, base their operation on the interaction of light with aerosols. One of the main products of these networks is the Aerosol Optical Depth (AOD). The AOD is obtained by measuring the direct irradiance of the Sun that reaches the Earth's surface with a photometer, since the amount of direct solar irradiance extinguished during its passage through the Earth's atmosphere depends on the AOD through the Beer-Bouguer-Lambert law. The AOD is related to the amount of aerosols present in the atmospheric column, and its spectral variation linked to the predominant size of the particles. Recent advances and improvements in photometric measurement instruments have made possible to adapt Sun direct measurements also to the Moon, being able to obtain AOD values also at night. This allows that in those areas with long night periods, mainly in the polar areas, will also be possible to obtain information related to aerosols. This helps to fill very relevant gaps in the data series obtained in these areas, which until now had only solar photometry.

During this work the analysis of the properties of the atmospheric aerosol is approached through the creation and improvement of new processes and products. Specifically, the development of new methods for the operational calculation of AOD in a network of instruments is presented, both for day and night. First, the calculation of the AOD during the day has been developed, describing step by step its process as well as meta-data used. In a second instance, this calculation has been adapted to the night, describing in the same way the models used and developing a new correction on these, which is proposed to improve the calculation of AOA at night. The products obtained by both methods have been contrasted with independent and reference data series, which has allowed us to ensure the quality of the algorithm.

Finally, deployed both products into production in the CÆLIS system has made it possible the detection of an extremely anomalous aerosol event at one of the sites that the Atmospheric Optics Group of the University of Valladolid operates: the Marambio site, in the Antarctica. With the help of other complementary measures and some atmospheric models, it has been discovered that the aerosols came from the biomass burning generated by bushfires located in Eastern Australia in late 2019. The detection of this event highlights the importance and the value of having routine measurements, automated processing and quality products that allow the analysis of the atmospheric aerosol properties.
\end{abstract}





\section{Introducción}

\subsection{Los aerosoles atmosféricos}

Se define como aerosol atmosférico al conjunto de partículas, ya sean sólidas o líquidas, que permanecen en suspensión en la atmósfera el tiempo suficiente para ser medidas (Willeke and Baron, 1993). Existen distintos tipos de aerosoles, debido a su origen principalmente, y su tamaño puede variar desde unos pocos nanómetros hasta varias decenas de micrómetros. Dependiendo de su origen se pueden clasificar en aquellos que han sido creados de forma natural (naturales), o en aquellos cuyo origen ha sido la actividad humana (antropogénicos). Los aerosoles de origen natural pueden ser, por ejemplo: la arena del desierto, ceniza volcánica, sal del mar, etc. mientras que entre los aerosoles antropogénicos se encuentran los generados en la combustión de carbón, petróleo, emisiones industriales, y los que se forman a partir de precursores (aerosoles secundarios). Siguiendo esta clasificación se puede decir que los aerosoles antropogénicos tienen un tamaño menor a un micrómetro y son los más numerosos de los presentes en la atmósfera. Por el contrario, los aerosoles de origen natural tienen un tamaño superior al micrómetro, generalmente, y aunque haya un número de partículas menor al aerosol antropogénico, estas aportan una cantidad mayor de masa en la atmósfera.

Debido a la variedad de tamaños que presentan los distintos aerosoles, se suele distinguir entre modo fino, con partículas de tamaño inferior a $0.5 \mu \mathrm{m}$, donde se incluyen los modos de nucleación y acumulación, y modo grueso, con partículas de tamaño superior a $0.5 \mu \mathrm{m}$. En la Figura 1.1 se puede ver una clasificación de ambos tipos, así como los mecanismos para su formación y eliminación. 


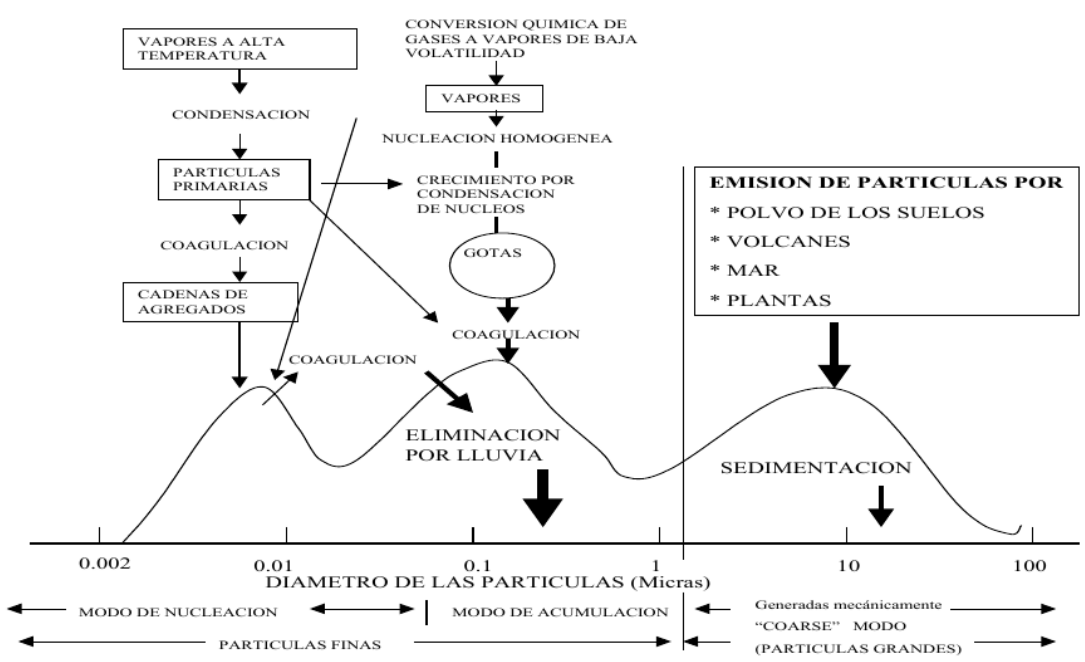

Figura 1.1: Forma típica de la distribución de tamaños de los aerosoles, con los tres modos y los mecanismos de formación y eliminación en la atmósfera (Toledano, 2005).

Por norma general, en la distribución de tamaños se observan dos campanas claramente diferenciadas, una de las campanas asociada a las partículas de modo fino y la otra a las partículas de modo grueso. Esta separación es importante porque las partículas pertenecientes a ambos modos tienen un origen y transformación diferentes. Su eliminación también se realiza de forma distinta, pertenezcan a uno u otro modo, si bien las partículas pertenecientes al modo fino suelen ser precipitadas al suelo por acción de la lluvia, las partículas más gruesas se eliminan por deposición en el suelo por acción de la gravedad o del viento (D’Almeida et al., 1991; Tegen et al., 1997).

Los aerosoles pueden ser transportados muy lejos de las fuentes de emisión, especialmente si alcanzan capas altas de la atmósfera (troposféra libre o incluso estratosfera). Es el caso del polvo mineral de los desiertos, el humo de grandes incendios forestales y sobre todo el aerosol de las grandes erupciones volcánicas (Boucher et al., 2013a; Hofmann, 1988). En función de su tamaño y de la altura a la que se encuentren en suspensión. Los aerosoles con un tamaño mayor suelen tener un tiempo de vida más corta debido a que la propia gravedad los acaba depositando en la superficie terrestre. Las partículas más pequeñas, por el contrario, pueden permanecer un tiempo más prolongado suspendidas en la atmósfera, pudiendo llegar a permanecer varios años en suspensión. Una vez que el aerosol está suspendido en la atmósfera éste será transportado en el mismo sentido y dirección que se muevan la masa de aire que lo contenga. Como se puede apreciar en la Figura 1.2 los aerosoles procedentes de cualquier fuente pueden ser trasportados, en función de la dinámica atmosférica, a prácticamente cualquier punto del planeta, especialmente si se encuentran en capas altas de la 


\subsection{Los aerosoles atmosféricos}

atmósfera.

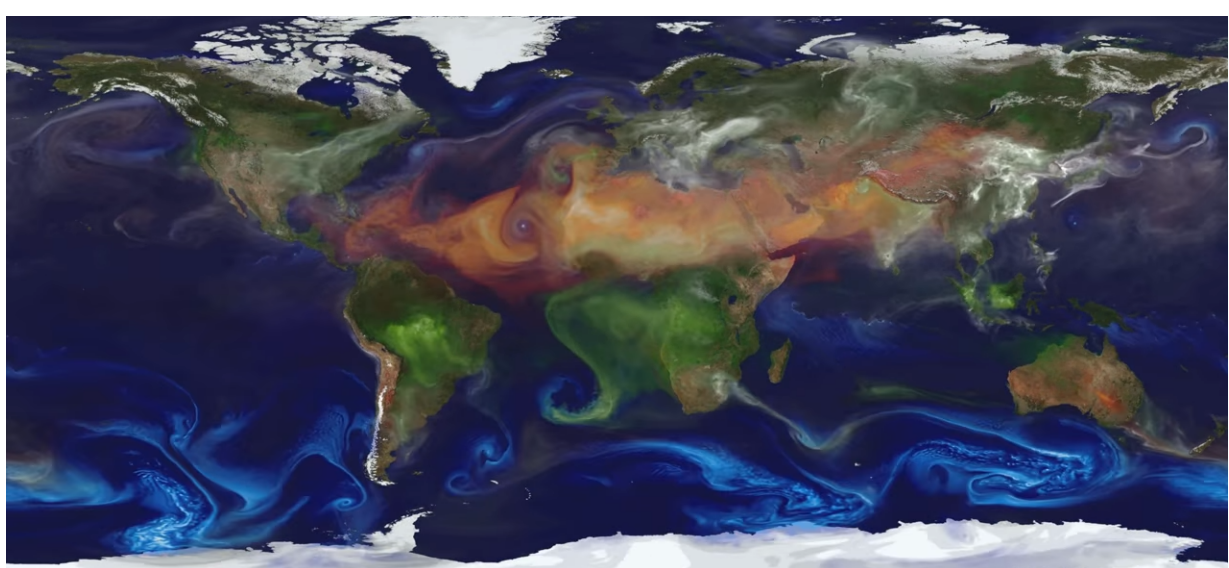

2006/09/04

Figura 1.2: Transporte de los aerosoles por todo el planeta Tierra. La imagen ha sido obtenida de la simu- lación que NASA Goddard's Global Modeling and Assimilation Office realizó para el periodo de tiempo comprendido entre agosto de 2006 y agosto de 2007 https: / / svs.gsfC .nasa.gov/cgi-bin/details.cgi?aid=30017). En este caso se ve el resultado de la simulación para el 27 de enero de 2007. Los colores corresponden a: desértico (rojo), sal marina (azul), polución antropogénica y orgánica (verde), y sulfatos (blanco).

Los aerosoles cerca de la superficie terrestre afectan fuertemente a la calidad del aire y a la salud humana al tratarse de partículas que son inhaladas por el sistema respiratorio. Durante las últimas décadas se ha observado un aumento en la polución debido, principalmente, a la actividad humana en regiones determinadas del planeta (Boucher et al., 2013a). La monitorización de los aerosoles implicados en estos eventos es muy importante para poder tomar las medidas políticas oportunas. Para poder tomar esas medidas es necesario un conocimiento de las propiedades del aerosol, lo cual se dificulta debido a la rapidez, tanto espacial como temporal, en que los aerosoles varían. De ahí la importancia de tener unos datos de aerosoles fiables y constantes.

Los aerosoles afectan al balance radiativo de la Tierra y la atmósfera terrestre, jugando por tanto un papel importante en el campo del calentamiento global, mediante las interacciones aerosol-radiación y aerosol-nube (Boucher et al., 2013a). El impacto de los aerosoles sobre el balance radiativo depende de las propiedades ópticas, químicas y microfísicas de los aerosoles, las cuales varían en general con el tipo de aerosol. Este impacto se suele cuantificar a través del denominado forzamiento radiativo, que representa la diferencia entre la radiación absorbida por la Tierra y la energía irradiada de vuelta al espacio (Shindell et al. 2013). Los aerosoles interaccionan directamente con la radiación solar (interacción aerosolradiación) y terrestre principalmente mediante la absorción y dispersión (scattering) de parte 
de la radiación incidente. Un aerosol poco absorbente suele tener un efecto directo neto de enfriamiento (forzamiento negativo) sobre la Tierra al enviar parte de la radiación solar incidente de vuelta al espacio mediante scattering; mientras que un aerosol muy absorbente puede causar un efecto contrario (forzamiento positivo) debido a su calentamiento por absorción de radiación. Estos se denominan efectos directos de los aerosoles. Los aerosoles además actúan como núcleos de condensación en la formación de nubes de agua y hielo, por lo que son capaces de modificar propiedades de las nubes tales como su albedo, el tamaño de gota, la precipitación o su tiempo de vida (interacciones aerosol-nube). Como las nubes también influyen en el balance radiativo, principalmente mediante la dispersión de radiación solar de vuelta al espacio, estas interacciones aerosol-nube también influyen indirectamente en el balance radiativo (Albrecht, 1989; Twomey, 1977).

El forzamiento radiativo de los aerosoles es actualmente el que presenta mayor incertidumbre, como se puede observar en la Figura 1.3. Por tanto el estudio de los aerosoles es fundamental para poder reducir la incertidumbre asociada a los aerosoles y sus interacciones con la radiación y las nubes y así poder realizar proyecciones climáticas más precisas.

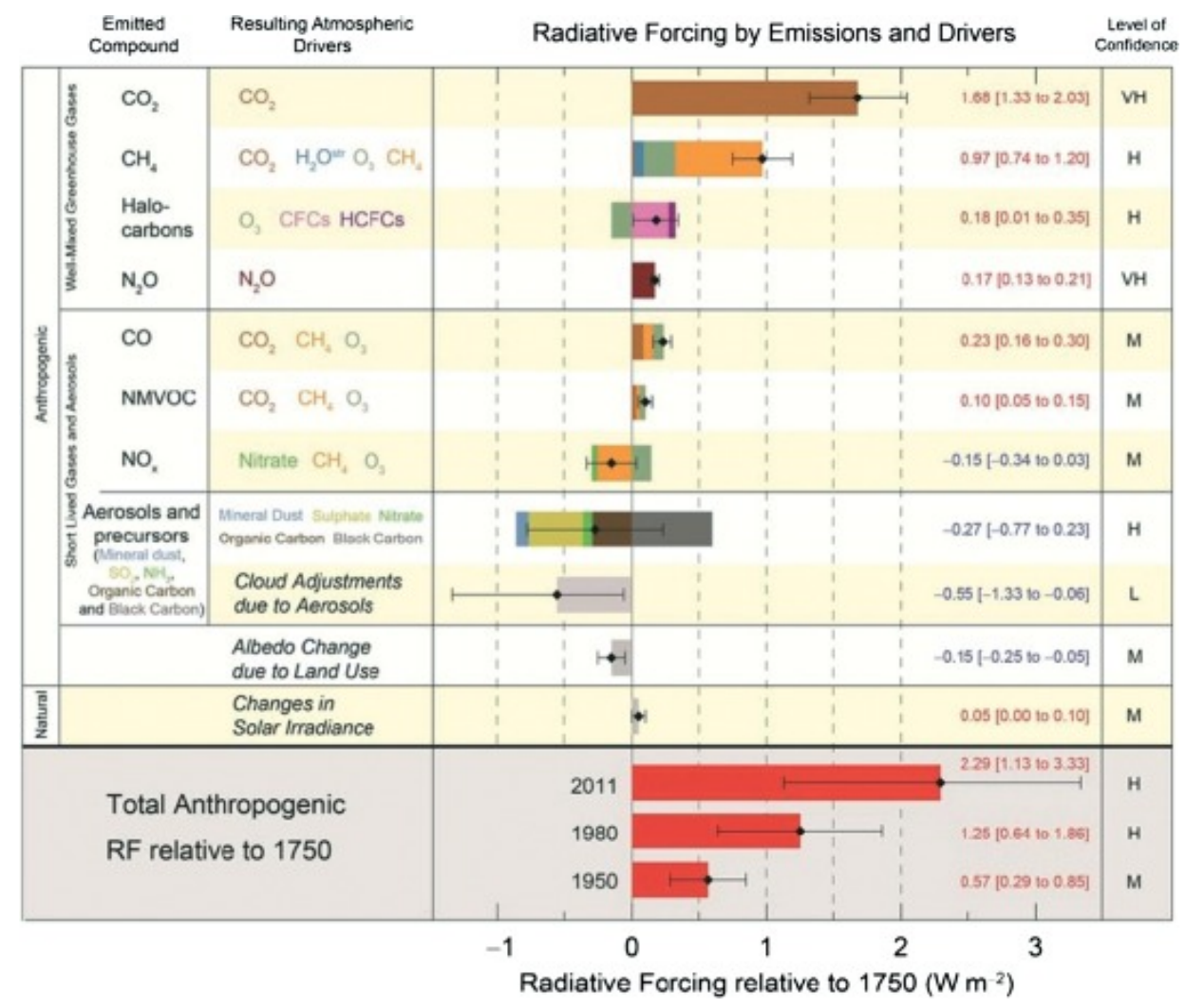

Figura 1.3: Forzamiento radiativo del clima terrestre, fuente de la imagenIPCC Fifth Assessment Report (AR5) [Intergovernmental Panel on Climate Change (IPCC), 2013]. 


\subsection{Técnicas de medida}

Existen distintas técnicas para medir y obtener información de los aerosoles atmosféricos. Por un lado existen técnicas in-situ, las cuales se basan en analizar directamente muestras de partículas recogidas presentes en el aire. Para ello se hace circular un flujo de aire, normalmente extraído mediante bombas, sobre una serie de filtros o instrumentos que, dependiendo del análisis (químico, físico, morfológico, etc.), se podrán analizar a posteriori o en tiempo real. Por la naturaleza de estas medidas, suelen estar más orientadas a analizar la calidad del aire. Las medidas in-situ son en general representativas localmente debido a que tienen un radio de acción pequeño, es decir, únicamente pueden analizar aquellos aerosoles que estén al alcance de las bombas que succionan el aire. En ocasiones se instala este tipo de instrumentación en medios móviles, por ejemplo en aviones (Mallet et al., 2016), para abarcar una región espacial mayor. Existen distinta instrumentación de este tipo, motivo por el cual dentro de la comisión Europea existe una legislación para unificar estas medidas y poder comparar la calidad del aire de distintas ciudades (https : / / ec.europa.eu/environ ment/air/quality/legislation/pdf/finalwgreportes.pdf).

Por otro lado se encuentran las técnicas remotas de medidas de aerosoles, más conocidas como teledetección, generalmente más enfocadas en el estudio del calentamiento global y el cambio climático. Estas técnicas, al contrario de las técnicas in-situ, no miden directamente el aerosol, si no que analizan como interacciona el aerosol con una fuente de iluminación. En teledetección se puede distinguir entre medidas a través de instrumentos de tierra (en superficie) o de satélites. Estas medidas difieren en la resolución que tienen, tanto temporal como espacial. Si bien los satélites tienen una mayor cobertura espacial pudiendo abarcar medidas por toda la Tierra, mientras con los instrumentos de tierra solo miden en el punto exacto donde están instalados. Sin embargo, la cobertura temporal que ofrecen los instrumentos instalados en la superficie es mayor que la de los satélites ya que estos últimos miden de continuo en el mismo punto, mientras que los satélites (a excepción de los geoestacionarios) solo toman una medida sobre la misma zona cada vez que realizan una órbita completa y vuelven a pasar sobre el mismo punto, tiempo que puede ser de hasta semanas.

Las medidas en superficie normalmente son más precisas que las de los satélites, por lo que es importante tomar medidas en superficie desde distintos lugares de la Tierra para poder calibrar y validar los productos proporcionados por los satélites. Por lo tanto, las medidas de satélite y en superficie son complementarias y ambas son necesarias. De aquí nace la necesidad de tener una red lo suficientemente tupida de instrumentos en superficie, como es el caso de la red fotométrica AERONET (AErosol RObotic NETwork; Holben et al., 1998). Igual de importante que tener una red con muchos instrumentos es que cada uno de estos instrumentos mida correctamente, para esto es necesario tener un control rutinario sobre 


\section{INTRODUCCIÓN}

todas aquellas estaciones de medida pertenecientes a la red. Para poder realizar de forma más óptima y correcta este chequeo sobre las estaciones es fundamental tener procesados de datos comunes en todas ellas, como se explica en la Sección 2.1.1. El grupo en el que se ha desarrollado este trabajo, el Grupo de Óptica Atmosférica de la Universidad de Valladolid (GOA-UVa), colabora con la red AERONET desde comienzos del 2000, pasando a colaborar en las labores organizativas y de gestión de la red en 2006, convirtiéndose en uno de los 3 centros oficiales de calibración de la red. Este centro de calibración tiene desde 2011 el respaldo de la Unión Europea mediante la participación en el proyecto ACTRIS (Aerosols, clouds and trace gases research infrastructure, www .actris .eu), el cual ahora mismo se encuentra en la fase de implementación para constituirse como una infraestructura europea de investigación.

A su vez, las técnicas de teledetección, se pueden clasificar en dos grupos según la fuente de iluminación utilizada: teledetección activa y pasiva. La teledetección activa usa una fuente de iluminación propia mientras que la teledetección pasiva se aprovecha de alguna fuente de iluminación existente, normalmente natural como el Sol, la Luna o las estrellas. Dentro de la teledetección activa destacan los sistemas LIDAR (Light Detection and Ranging). Estos sistemas emiten pulsos de luz monocromática, mediante un láser pulsado, normalmente apuntando al cenit. Los LIDAR pueden estar instalados a nivel de superficie o en dispositivos aéreos, como pueden ser satélites o aviones. Cabe destacar que las medidas obtenidas por los sistemas LIDAR son de gran valor cuando se combinan con otras medidas como las obtenidas por los fotómetros (Benavent-Oltra et al., 2017; Lopatin et al., 2013). Estos sistemas LIDAR son muy costosos y su uso está limitado a usuarios cualificados. Por el contrario, existen otros instrumentos, los Ceilómetros, cuyo uso es más sencillo y automatizado y tienen un coste menor a costa de una calidad de las medidas menor. El uso de los Ceilómetros está más extendido y su sinergia con los instrumentos de superficie aporta también información acerca de los aerosoles (Román et al., 2018).

\section{Fotometría solar}

Respecto a la teledetección pasiva, los instrumentos más utilizados en superficie suelen ser fotómetros espectrales, que miden la radiación proveniente de fuentes de iluminación como el Sol o la Luna a diferentes longitudes de onda. En el caso de los instrumentos a bordo de satélites estos suelen medir, dependiendo del rango espectral, la radiación reflejada o dispersada (solar) o emitida (térmica) por la superficie terrestre y la atmósfera.

A través de la teledetección pasiva se puede obtener una de las magnitudes fundamentales en el análisis de los aerosoles atmosféricos: el espesor óptico de aerosoles (AOD del inglés 
Aerosol Optical Depth). La ecuación fundamental para calcular el AOD es la ley de BeerBouguer-Lambert (Cachorro et al., 1987; Shaw, 1976), la cual está descrita para el caso de la fotometría solar en la ecuación 1.1 .

$$
V(\lambda)=V_{0}(\lambda) \cdot R^{-2} \cdot e^{-\tau(\lambda) \cdot m}
$$

donde $R$ es la distancia Tierra-Sol medida en unidades astronómicas (UA); $m$ es la masa óptica, la cual se relaciona con el camino óptico recorrido por la radiación medida Kasten and Young (1989); $\tau$ es el Espesor Óptico Total (TOD del inglés Total Optical Depth) para una longitud de onda $\lambda$ concreta; y $V$ y $V_{0}$ son, respectivamente, la señal de la irradiancia directa medida por el fotómetro y la de la irradiancia extraterrestre (la radiación solar que llega a lo más alto de la atmósfera terrestre para 1 UA) ambas a la longitud de onda $\lambda$.

Una vez se tiene calculado el TOD se puede separar en cada uno de sus componentes como se muestra en la ecuación 1.2, donde $\tau_{a}$ es la contribución que hacen los aerosoles atmosféricos al TOD y $\tau_{R}$ y $\tau_{g}$ es la contribución que hacen los gases al TOD a través de los mecanismos de scattering de Rayleigh $\left(\tau_{R}\right)$ y de absorción $\left(\tau_{g}\right)$. Nótese que el espesor óptico de las nubes no se incluye ya que las medidas fotométricas bajo nubes se suelen descartar.

$$
\tau(\lambda)=\tau_{a}(\lambda)+\tau_{R}(\lambda)+\tau_{g}(\lambda)
$$

Si se tiene en cuenta que cada uno de estos componentes está situado a distintas alturas y, por lo tanto, cada uno va a tener una masa óptica distinta, la ecuación 1.1 se puede representar de la siguiente forma:

$$
V(\lambda)=V_{0}(\lambda) \cdot R^{-2} \cdot e^{-\left[\tau_{a}(\lambda) \cdot m_{a}+\tau_{R}(\lambda) \cdot m_{R}+\tau_{g}(\lambda) \cdot m_{g}\right]}
$$

Pudiendo calcular el AOD como se muestra en la ecuación 1.4

$$
\tau_{a}(\lambda)=-\frac{1}{m_{a}} \cdot\left[\ln \left(\frac{V(\lambda)}{V_{0}(\lambda) \cdot R^{-2}}\right)-\tau_{R}(\lambda) \cdot m_{R}-\tau_{g}(\lambda) \cdot m_{g}\right]
$$

En este caso el AOD a la longitud de onda $\lambda$ se puede calcular para cada medida $V$ del fotómetro a la misma longitud de onda, siempre que se conozca $V_{0}$ a esa longitud de onda, además del espesor óptico de gases (Rayleigh y absorción) que se puede obtener a través de climatologías existentes. Para calcular $V_{0}$, que es un valor fijo (aunque variará ligeramente con la degradación del fotómetro) pero distinto para cada longitud de onda, se calibra el fotómetro mediante intercomparación con otro fotómetro de referencia, o mediante la técnica Langley-plot (Shaw, 1983). La técnica Langley-plot se basa en realizar medidas de irradiancia solar cerca del orto o el ocaso, donde la masa óptica varía rápidamente, y $V_{0}$ se puede calcular a través de la ecuación 1.5 que surge de tomar logaritmos en la ecuación 1.1 . 


$$
\ln [V(\lambda)]=\ln \left[V_{0}(\lambda) \cdot R^{-2}\right]-\tau(\lambda) \cdot m
$$

Asumiendo que el espesor óptico de la atmósfera se ha mantenido estable y constante durante estas medidas, mediante un ajuste lineal de mínimos cuadrados de $\ln (V)$ en función de $\mathrm{m}$ se obtiene como ordenada en el origen $\ln \left(V_{0} \cdot R^{-2}\right) \mathrm{y}$, por tanto, $V_{0}$ despejando.

El AOD está relacionado con la turbiedad presente en la columna atmosférica total y varía espectralmente según la ley de Ånsgtröm (Angström, 1961):

$$
\tau_{a}(\lambda)=\beta \cdot \lambda^{\alpha}
$$

donde $\lambda$ es la longitud de onda (en micras); $\tau_{a}(\lambda)$ es el AOD a la longitud de onda $\lambda$; $\beta$ es el parámetro de turbiedad de Ånsgtröm; y $\alpha$ el exponente de Ånsgtröm, el cual representa la variabilidad espectral del AOD y está ligado con el tamaño del aerosol, siendo mayor cuanto menor es el valor de $\alpha$. Conocido el AOD a dos o más longitudes de onda se puede calcular la turbiedad y el exponente de Ånsgtröm. Cabe remarcar que el AOD es una propiedad integrada en toda la columna atmosférica y por tanto no se puede distinguir entre capas a distintas alturas en la atmósfera.

\section{Fotometría lunar y estelar}

Todo lo explicado hasta ahora se basa en el uso del Sol como fuente de iluminación (fotometría solar). El problema de usar esta fuente de iluminación es que durante la mitad del año no está disponible, si bien esta discontinuidad es intermitente en las latitudes medidas, todos los días sale y se pone el Sol, cuando nos desplazamos a las zonas polares esta discontinuidad se convierte en un problemas de mayor envergadura ya que el Sol no sale durante meses durante la noche polar, lo que hace que no se tenga información del AOD en las zonas polares durante periodos de tiempo muy prolongados. Para solventar este problema, en los últimos años se han realizado avances técnicos en la instrumentación consiguiendo que los fotómetros solares sean capaces de realizar medidas de la irradiancia directa lunar, varios ordenes de magnitud menor que la solar. Con esta nueva técnica se pretende completar, aunque sea parcialmente, la ausencia de datos producida por la ausencia del Sol en dichas regiones.

Esta nueva técnica de medida supone nuevos retos, debido a que se deben adaptar los algoritmos y procesados de datos existentes para obtener productos similares a los que se obtienen con la fotometría solar.

A priori se pueden aplicar también la ley de Beer-Bouguer-Lambert a la fotometría lunar para calcular el AOD sustituyendo en la ecuación $1.1 V_{0}(\lambda) \cdot R^{-2}$ por la irradiancia lunar extraterrestre a esa longitud de onda, es decir, la irradiancia lunar que llega a la parte más 
alta de la atmósfera. El problema es que, a diferencia del Sol, la Luna no emite radiación visible si no que a la Tierra llega la radiación solar que la Luna refleja. Esto hace que la irradiancia lunar extraterrestre esté en constante variación al depender de distintos factores que van cambiando con el tiempo, tales como el ángulo de fase de la Luna, las distancias SolLuna y Luna-Tierra y la reflectancia angular de la superficie lunar iluminada. Para conocer la irradiancia lunar a cada momento, y poder derivar el AOD, se suelen utilizar modelos empíricos, siendo el modelo ROLO (RObotic Lunar Observatory; Kieffer and Stone (2005)) el de uso más extendido, así como su implementación RIMO (ROLO Implementation for Moon's Observation; Barreto et al. (2019)). Sin embargo, varios estudios señalan falta de exactitud en estos modelos (Lacherade et al., 2013; Uchiyama et al., 2019; Viticchie et al., 2013), la cual puede propagarse en el cálculo del AOD proporcionando valores erróneos.

De todos los nuevos retos de la fotometría lunar y como se resuelven para un caso concreto se habla en la sección 3.2 .

Una técnica menos extendida para el cálculo del AOD por la noche es la fotometría estelar. Al igual que la fotometría solar y lunar, esta técnica se basa en realizar medidas de la radiación emitida por alguna estrella que llega a la Tierra. Para poder realizar estas medidas de la forma más precisa posible se utiliza un telescopio, para captar la mayor cantidad posible de radiancia evitando introducir luz parásita emitida por otras fuentes de iluminación. Mediante la ley de Beer-Bouguer-Lambert (Shaw, 1976) y la técnica Langley-plot para la calibración, se consigue obtener valores de AOD con las fórmulas antes definidas. Existen otros métodos más complejos para calcular el AOD con estos fotómetros, como el método de "dos estrellas", pero necesitan de un conocimiento preciso de la radiación extraterrestre de varias estrellas. Este tipo de medidas tienen bastante precisión si bien, debido a la complejidad de funcionamiento de los fotómetros estelares, no está del todo extendida, siendo escasos los fotómetros estelares operando (actualmente no más de cinco en todo el mundo; Barreto et al. (2019)).

\section{Radiancia de cielo y algoritmos de inversión}

Además del AOD existen otras propiedades de los aerosoles que pueden ser obtenidas mediante fotómetros a partir de medidas de la radiancia del cielo y también del AOD. Para ello se utiliza la información que llega a los fotómetros de la radiancia proveniente del scattering que sufre la radiación solar al interaccionar con el aerosol atmosférico. Para obtener dichas propiedades, complejos y computacionalmente costosos métodos de inversión son requeridos (Dubovik and King, 2000; Dubovik et al., 2006, 2014). Para que estos métodos sean fiables se requiere de unas condiciones de cielo despejado de nubes. Dos de las propiedades 


\section{INTRODUCCIÓN}

de los aerosoles de mayor interés, obtenidas con este tipo de medidas, son: la distribución de tamaños y el albedo de dispersión simple (SSA del inglés Single Scattering Albedo).

La distribución volúmica de tamaños (PSD del ingés Particle Size Distribution), que proporciona información de la cantidad de partículas (en volumen) que hay en la columna atmosférica y además de que tamaños son esas partículas. La PSD se puede definir matemáticamente como:

$$
P S D(r)=\frac{d v}{d \ln (r)}
$$

Donde $v$ es el volumen que ocupan las partículas por unidad de superficie para un radio $r$ de las partículas. Las unidades en las que se da la distribución de tamaños son en $\frac{\mu m^{3}}{\mu m^{2}}$. Esto indica la concentración en volumen de partículas existente para un radio determinado. Cabe destacar que, al tratarse de una concentración en volumen, la concentración de partículas pequeñas aportara menos peso a la distribución incluso si hay mayor número de partículas (ocupan menos volumen). Un ejemplo cualitativo de distribución de tamaños se observa en la curva de la Figura 1.1 en función del radio de las partículas, pudiéndose observar la presencia de concentración de aerosoles de distintos modos (dos finos y uno grueso).

El SSA se define como la fracción de radiación extinguida al interactuar con los aerosoles debido a la dispersión o scattering. El SSA puede tomar valores entre 0 y 1 y se puede interpretar como la probabilidad que tienen un fotón de sufrir scattering al interactuar con una partícula. Si el aerosol es completamente absorbente el SSA será 0, mientras que si el aerosol es completamente dispersor el valor del SSA será 1. El SSA proporciona información sobre la absorción de un aerosol, lo cual es relevante para conocer el signo del forzamiento radiativo de ese aerosol. Los valores que suele tomar el SSA están comprendidos entre 0.7 y 1, y están ligados a la longitud de onda incidente y al tipo de aerosol. Por ejemplo, para un aerosol de tipo desértico los valores típicos son de 0.93 para la longitud de onda de 440 nm y de 0.99 para la longitud de onda 1020nm, sin embargo, para un aerosol de quema de biomasa los valores típicos son de 0.88 para la longitud de onda de $440 \mathrm{~nm}$ y de 0.78 en 1020nm, como se puede ver en Dubovik et al. (2002).

Junto a la distribución de tamaños, el índice de refracción, tanto su parte real (hace referencia a la dispersión que sufre la radiación por los aerosoles) como imaginaria (hace referencia a la extinción que sufre la radiación al ser absorbida por los aerosoles) y la fracción de partículas esféricas (proporción de partículas esféricas en relación con las partículas totales) son las salidas directas de estos algoritmos de inversión. 


\subsection{Objetivos}

Como se ha visto a lo largo de este capítulo, el estudio de los aerosoles atmosféricos es de crucial importancia para adquirir un conocimiento mayor sobre cómo se comportan estos aerosoles y la influencia que tienen en el clima y el calentamiento global. Para poder estudiar $\mathrm{y}$ detectar de forma inmediata las propiedades de los aerosoles hay que estar preparados y contar con un conjunto de herramientas que permitan, entre otras cosas, el análisis de eventos de aerosol y sus propiedades. El GOA-UVa, grupo en el que se ha realizado esta tesis, lleva desde sus orígenes dedicándose al estudio de estos aerosoles, a través de métodos ópticos. Debido a su dilatada experiencia en la red AERONET cuenta con una serie de estaciones repartidas a lo largo del planeta que le permite medir los aerosoles en sitios remotos. Algunas de estas estaciones se encuentran en el Ártico o en la Antártida, lugares idóneos para el estudio de los aerosoles de origen natural, debido a sus condiciones climáticas y meteorológicas. Así mismo, el GOA-UVa gestiona un centro de calibración de fotómetros de la red AERONET.

Dentro de este contexto, el objetivo de esta tesis es dotar a la comunidad de aerosoles de un conjunto de herramientas dedicadas al estudio de los aerosoles atmosféricos y que permitan, a su vez, la detección de eventos extraordinarios. Estas herramientas ayudarán al GOA-UVa a gestionar y mantener los equipos que se calibran bajo su supervisión. Para ello se buscarán los siguientes objetivos:

- Desarrollar de un algoritmo que permita calcular el espesor óptico de aerosoles con suficiente precisión y exactitud, que funcione de forma operacional y robusta, y validar este producto con el AOD de referencia, en este caso el de AERONET. Este algoritmo deberá funcionar para todos los equipos que pertenecen a la red AERONET y que el GOA-UVa gestiona. Una vez se tenga un producto de AOD de suficiente calidad y validado también se pretende desarrollar un algoritmo de eliminación de nubes (Cloud Screening) que permita seleccionar datos libres de nubes.

- Una vez se tenga un algoritmo capaz de calcular el AOD se quiere adaptar este algoritmo a las medidas que, los fotómetros CIMEL más modernos, son capaces de hacer, utilizando la irradiancia lunar. Para ello se tendrá que usar el modelo de radiancia lunar RIMO y corregir diversos factores. Para ver que la adaptación del algoritmo y la corrección del modelo son correctas se quiere comparar el AOD obtenido mediante esta técnica usando como referencia el obtenido con medidas alternativas de un fotómetro estelar. 
- Poner en funcionamiento y producción ambos algoritmos para comprobar si son capaces de detectar eventos extraordinarios de aerosoles.

\subsection{Estructura de la tesis}

Esta tesis se ha estructurado en 4 capítulos. En el capítulo de Introducción se muestra en que punto está el estudio de los aerosoles así como las distintas técnicas por las que se lleva a cabo este estudio, mostrando a continuación los objetivos de la tesis. En el capítulo 2 se muestra la instrumentación y metodología usada para la realización de esta tesis. En el capítulo de Resultados se muestra cada uno de los 3 artículos que componen este trabajo. En el primer artículo se describe el proceso, usado en CÆLIS, para implementar el AOD durante el día, así como las pruebas realizadas para su validación (González et al., 2020b). El segundo artículo adapta el algoritmo de cálculo delAOD diurno desarrollado en el primer artículo a las medidas con la irradiancia de la luna. En él se corrige el modelo RIMO, que calcula la irradiancia lunar y se valida esta corrección con las medidas realizadas por el fotómetro estelar instalado en la estación de medida de la Universidad de Granada (España) (Román et al., 2020). Por último, en el tercer artículo, se muestra como la utilización de los datos generados por ambos algoritmos son valiosos para detectar eventos anómalos de aerosoles. Para demostrar este hecho se indaga en profundidad sobre un evento detectado en la estación de Marambio (Antártida Argentina) cuya procedencia fueron los incendios ocurridos en Australia durante los últimos días de diciembre de 2019 (González et al.,2020a). Finalmente, se presentan en el último capítulo las conclusiones y líneas futuras de este trabajo.

Siguiendo este esquema se presenta ordenadamente cada uno de los artículos científicos y como entre ellos se forma un hilo argumental común que da como resultado la realización de los objetivos expuestos en la sección 1.3 . 


\section{Instrumentación y datos}

\subsection{Redes de medida}

Debido a la importancia del estudio de los aerosoles, como ya se ha mencionado en la sección 1.1, existen numerosas redes de instrumentos en superficie dedicadas al estudio de estos aerosoles. Si nos centramos únicamente en las redes basadas en técnicas de teledetección podemos nombrar, como alguna de las más importantes:

- GAW-PFR: gobernada por el Physikalisch Meteorologisches Observatorium Davos que pertenece al World Meteorological Organization (PMOD-WMO) y cuyo principal instrumento de medida es el Precision Filter Radiometer (PFR) que, actualmente, cuenta con su versión tanto para el Sol como para la Luna. Existe a su vez un modelo adaptado para medir a lo largo de todo el espectro (Kazadzis et al., 2018a).

- SKYNET: que se organiza de forma regional en 7 subredes diferentes, cuya división atiende a motivos de proximidad geográfica. El elemento principal de esta red es el Prede, que mide tanto al Sol como al cielo. Actualmente cuentan con una configuración del instrumento capaz de medir a la Luna (Uchiyama et al., 2019).

- AERONET: red gobernada por NASA (descrita en la sección 2.1.1), cuyo instrumento principal es el fotómetro CIMEL CE318 (descrito en la sección 2.2.

Esta tesis se centra en los datos medidos con el instrumento CIMEL CE318 y que pertenecen a la red AERONET, por lo que se describe con más detalle a lo largo de este capítulo. 


\subsubsection{AERONET}

Como hemos comentado antes, una de las redes de más importantes dedicada al estudio de los aero- soles atmosféricos es la red AERONET (https: / / aeronet.gsfc.nasa.go V) (AErosol RObotic NETwork, Holben et al. (1998)). Esta red fue creada en la década de 1990 por la NASA y el Laboratorio de Óptica Atmosférica de la Universidad de Lille (LOA), Francia. El objetivo con el que nace esta red es el estudio, de forma rutinaria y en cualquier punto del planeta, de los aerosoles atmosféricos para poder validar las medidas obtenidas por los satélites. Para poder satisfacer este objetivo, actualmente cuenta con más de 500 estaciones, midiendo de forma periódica, repartidas por todo el planeta, como se puede ver en la figura 2.1 .

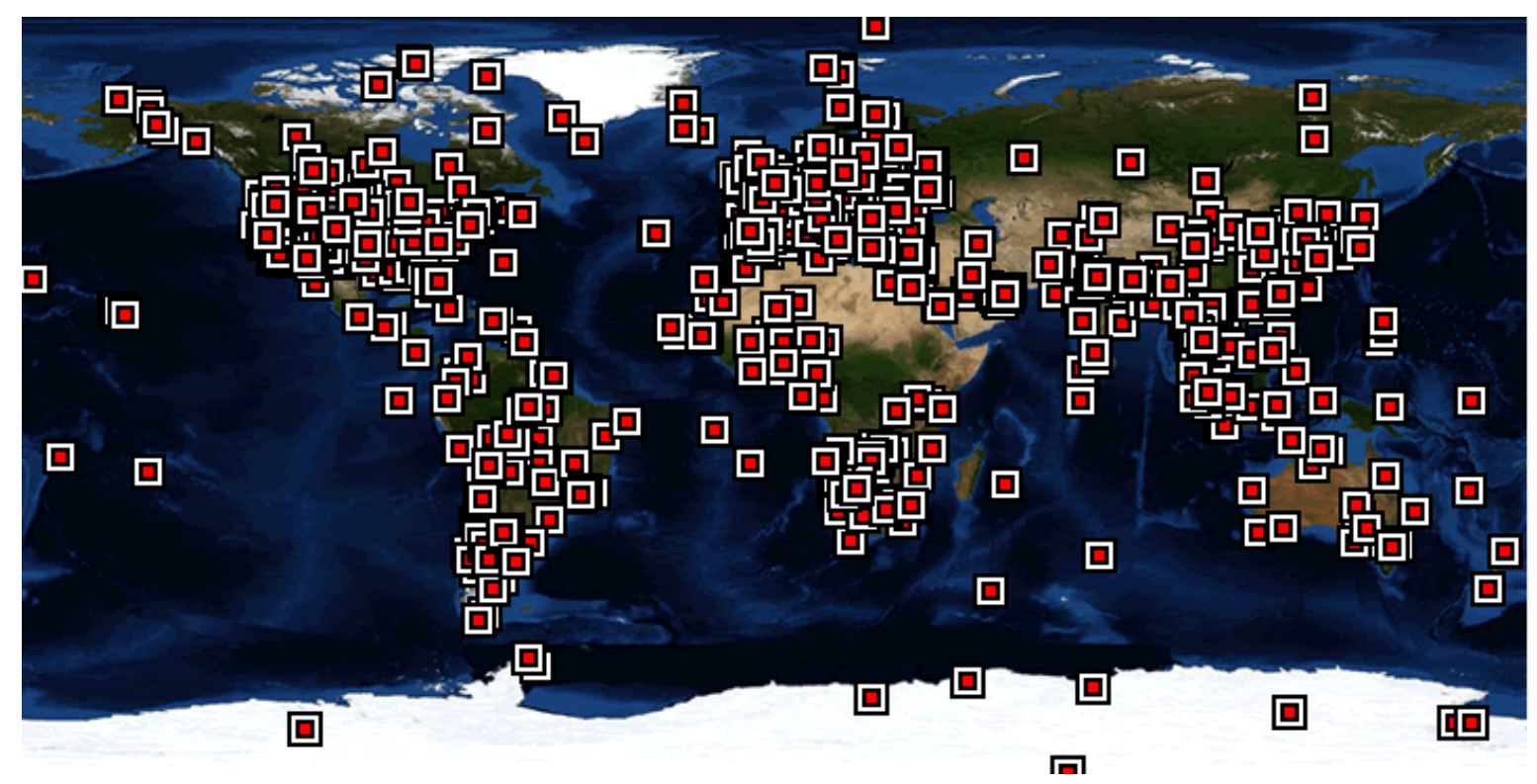

Figura 2.1: Ubicación de cada una de las estaciones de medida pertenecientes a la red AERONET. Imagen obtenida de la propia página web de la red AERONET (https://aeronet. gsfc.nasa.gov/cgi-bin/site_info)

AERONET se define como una federación de redes, encargándose cada una de esas redes de la calibración, supervisión y mantenimiento de un conjunto de estaciones de la red. Originalmente todos los instrumentos que pertenecían a la red AERONET eran calibrados por la NASA y el LOA, pero, a medida que el número de instrumentos fue creciendo, esta labor comenzó a hacerse muy costosa para dos laboratorios y se incorporó un tercer grupo para ayudar en esta labor. Desde el 2006 el Grupo de Óptica Atmosférica de la Universidad de Valladolid (GOA-UVa) pasa a ser uno de los 3 centros oficiales de calibración de la red AERONET. 
Como el objetivo de esta red es realizar medidas en distintos puntos del planeta para validar las medidas de los satélites, estas medidas han de ser directamente comparables. Para lograr este objetivo, AERONET estableció unos protocolos de calibración, que se han de cumplir tanto por el centro de calibración como por los propietarios de la estación de medida. Uno de estos requisitos es la utilización de un instrumento común a toda la red, aunque este puede tener distintas configuraciones (ver sección 2.2). Para que una estación pertenezca a la red AERONET se han de cumplir estas dos condiciones, y el resultado de cumplirlas es la obtención de unas medidas de gran calidad y homogeneidad. Estas medidas, debido a los estrictos protocolos de calibración de la red son trazables en su totalidad, esto quiere decir que para cada medida se conoce toda la meta-información asociada a la medida, así como unos coeficientes de calibración exclusivos de cada instrumento y cada medida.

El acceso a los datos generados por la red AERONET es libre y gratuito, cualquier usuario puede consultar y usar los datos sin previo registro, pudiendo utilizar estos datos para publicaciones científicas siempre bajo agradecimiento a la institución responsable de la estación.

Como se explica en la sección 2.2 el instrumento CIMEL CE318 realiza dos bloques de medidas, de irradiancia solar y de radiancia de cielo. Cada una de estas medidas requiere de un protocolo de calibración distinto.

Las medidas de irradiancia solar se calibran por inter-comparación con unos fotómetros de referencia llamados máster. Estos fotómetros máster se calibran por el método Langley en las estaciones de Izaña (Tenerife, España) y Mauna Loa (Hawai, Estados Unidos) (Toledano et al., 2018). Por otro lado, las medidas de radiancia de cielo se calibran en el laboratorio con una esfera integrante.

Es necesario calibrar cada uno de los fotómetros que pertenecen a la red en periodos de un año de medida para minimizar los cambios en la calibración causados por la degradación de los componentes del fotómetro. Antes de comenzar el periodo rutinario de medida se realiza una pre-calibración al instrumento. Cuando ha realizado todo el periodo de medida rutinaria se le realiza una post-calibración. De esta forma, el equipo cuenta con unos coeficientes de calibración propios para cada fecha y hora de la medida interpolados linealmente entre los obtenidos en pre y post-calibración. Solo entre una post-calibración y una pre-calibración se realiza un mantenimiento al equipo para realizar cualquier reparación pertinente y actualizar o mejorar cualquiera de sus elementos. Esta acción nunca se realizará en el periodo que abarca ambas calibraciones, consiguiendo unas medidas homogéneas durante todo el periodo de medida.

El procesamiento de datos de esta red está centralizado, realizándose en los servidores del Goddar Space Flight Center (Washington DC, Estados Unidos). Estos servidores son la 


\section{INSTRUMENTACIÓN Y DATOS}

única fuente de datos oficiales llevando un control exhaustivo de lo que se hace con cada uno de los instrumentos que pertenecen a la red. Para ello, siempre que se realiza cualquier reemplazo, mantenimiento o calibración en alguno de los equipos, estos cambios han de quedar notificados en los servidores mencionados de la NASA. Así se consigue que las medidas sean completamente trazables.

\subsubsection{GOA Calibration Facillity}

El GOA-UVa fue fundado en 1996 con el objetivo principal de estudiar los aerosoles atmosféricos a través de métodos ópticos. Desde su origen el grupo se centró en esta labor, compaginándola con otras tareas relacionadas. Esto le lleva a ser un grupo con una experiencia demostrada en aerosoles atmosféricos (Cachorro et al., 1987; Toledano et al., 2007; Torres et al., 2014), teledetección remota con satélites (Bennouna et al., 2011, 2013; Cachorro et al., 2010) y radiación solar (Cachorro et al., 1985, 2001; Mateos et al., 2014).

En 2006 pasa a liderar una red formada por Universidades y otras instituciones Españolas creada con el objetivo de implantar una subred de medidas de aerosoles en la Península Ibérica, la Red Ibérica de Medidas de Aerosoles (RIMA). Debido a su dilatada experiencia en el manejo de instrumentos de teledetección y a su laboratorio equipado con la instrumentación necesaria y personal debidamente formado en su utilización, se propone como nuevo centro de calibración de la red AERONET. Trasncurridos unos años se acaba la entidad de la red RIMA, aunque no con las colaboraciones entre los miembros originales de la red. En este momento el GOA-UVa continua con sus labores de calibración y mantenimiendo de los equipos de la red AERONET que se le habían atribuido dentro de RIMA. Para ello se crea la infraestructura de calibración del GOA (de su nombre en inglés GOA Calibration Facillity). Esta infraestructura sigue contando con el personal altamente cualificado y la instrumentación necesaria para realizar tal tarea, aunque, según iban trascurriendo los años, se han añadido a la infraestructura nuevos miembros y nueva instrumentación, siempre orientado a cumplir con los estándares exigidos por la red AERONET para la calibración de sus equipos (Toledano et al., 2011). Tras la creación de esta infraestructura se estrecha la colaboración del grupo con el resto de integrantes de la red AERONET y la participación del GOA-UVa en las estaciones de calibración de AERONET crece año tras año.

Incorporar las calibraciones de AERONET a las tareas del GOA-UVa desencadenó la imposibilidad de seguir realizando de forma manual la revisión de los datos, por lo que en 2009 el GOA-UVa decide dar un salto hacia la automatización e incorpora personal técnico formado en el campo de la Ingeniería Informática. Es en este momento cuando se desarrolla la herramienta CÆLIS con el objetivo de ayudar a la gestión de todas las estaciones de la red AERONET calibradas por el GOA-UVa (Fuertes et al., 2018). Esta herramienta da lugar al 
desarrollo de nuevos productos por el grupo y le coloca en un lugar privilegiado para la realización de ciertos trabajos, como se demuestra en los proyectos nacionales e internacionales en los que el GOA-UVa ha participado; alguno de los más importantes hasta la fecha son el proyecto Europeo ACTRIS (iniciado en 2011 y continuado con dos versiones más hasta 2019) y el proyecto del plan nacional ePOLAAR (iniciado en 2019 y es la continuación de otro proyecto de características similares llamado POLARMOON cuya duración fue de 2016 a 2018). Actualmente el GOA-UVa se considera un grupo de investigación multidisciplinar que cuenta entre sus filas con personal con formación en Física, Óptica, Ingeniería Informática y personal técnico orientado a las labores operativas de la red.

El grupo no se centra únicamente en el manejo del fotómetro solar CIMEL, también cuenta con instrumentación complementaria para el estudio de los aerosoles por otras técnicas de medida. Actualmente tiene amplia experiencia en la utilización de cámaras todo cielo, estando involucrado en la implantación de una red de cámaras de cielo en distintas estaciones (Román et al., 2017a b). También cuenta con un ceilómetro (CHM15k; Lufft manufacturer) instalado en la estación de Valladolid utilizado para añadir información sobre los aerosoles (Cazorla et al., 2017; Herreras et al., 2019, Román et al. 2018), así como un radiómetro cenital (ZEN R-52; Sieltec Canarias SL) (Almansa et al., 2017, 2020) y con gran experiencia en el uso de radiómetros de banda ancha (García et al., 2014; Mateos et al., 2014).

Si bien el GOA-UVa calibra fotómetros de estaciones ajenas al grupo, existe un conjunto de estaciones con instrumentación perteneciente al grupo, y cuya gestión y mantenimiento corren a cargo del grupo. Estas estaciones se pueden ver en la Figura 2.2, y son las estaciones de Ny-Ålesund (Svalbard, Noruega) compartida con el Alfred-Wegener-Institut (AWI), Andenes (Noruega) compartida con el Norwegian Institute for Air Research (NILU), Palencia y Valladolid (España) en propiedad del GOA-UVa, Izaña y Teide compartidas con la Agencia Estatal de Meteorología (AEMET), Camagüey (Cuba) compartida con el Instituto de Meteorologia de la República de Cuba (INSMET) y Marambio (Antártida Argentina) compartida con el Servicio Meteorológico Nacional de Argentina (SMN) y el Finish Meteorological Insstitute (FMI). En todas ellas la instrumentación instalada y la responsabilidad sobre los datos pertenece al GOA-UVa.

Todo esto convierte al GOA-UVa en un grupo puntero en el estudio de los aerosoles atmosféricos y con una labor operativa crucial para el mantenimiento de la red AERONET. Esto se transforma en un profundo conocimiento de la instrumentación con la que se realizan las medidas que facilita la interpretación de los datos y la revisión y mantenimiento de las estaciones de la red AERONET de las que es responsable. 


\section{INSTRUMENTACIÓN Y DATOS}

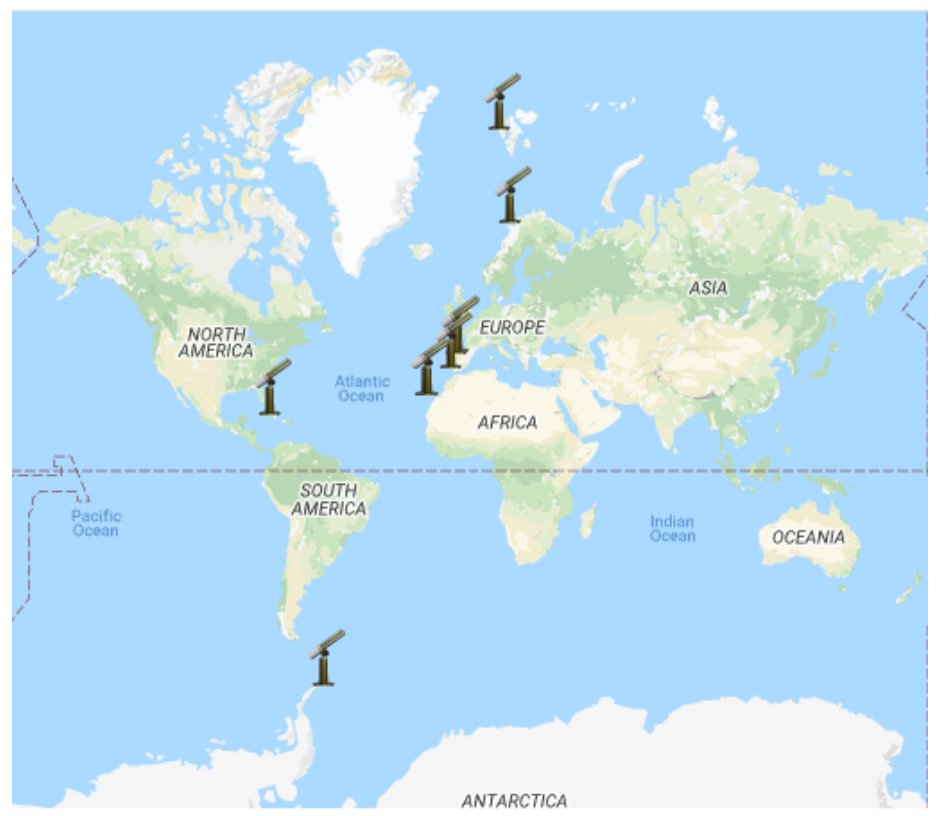

Figura 2.2: Ubicación de las estaciones AERONET del GOA-UVa, de Norte a Sur se ven las estaciones de Ny-Ålesund (Noruega), Andenes (Noruega), Palencia, Valladolid, Izaña, Teide, Camagüey (Cuba) y Marambio (Antártida, Argentina)

\subsection{CIMEL CE318}

El fotómetro CIMEL CE318 es el instrumento estándar para todas las estaciones que pertenecen a la red AERONET. Se trata de un espectrorradiómetro automático y de campo desarrollado por la casa francesa Cimel Electronique y ha sido el instrumento utilizado por AERONET desde sus comienzos.

El funcionamiento de este equipo se basa en realizar medidas de radiación, proveniente tanto del cielo como del Sol (o de la Luna en los equipos más modernos), en una serie de longitudes de onda que se seleccionan gracias a una serie de filtros interferenciales estrechos, que están instalados en el interior de la cabeza sensora del fotómetro. Cada uno de estos filtros, midiendo a las distintas fuentes de luz (Sol, cielo o Luna) define lo que se conoce como canales, los cuales corresponden con una longitud de onda específica, así como con unos coeficientes de calibración y amplificación electrónica específicos. Esto hace, que con un mismo detector se puedan realizar medidas a las distintas fuentes de luz. El fotómetro está instalado en un robot seguidor de dos ejes (cenital y acimutal) que permite realizar medidas en distintas posiciones de la bóveda celeste. La programación de medidas y qué tipo de medida realizar en cada momento está gestionado por una caja de control que se encarga de realizar, de forma apropiada, la secuencia de medidas. Una imagen de un fotómetro Cimel la podemos ver en la Figura 2.3 . 


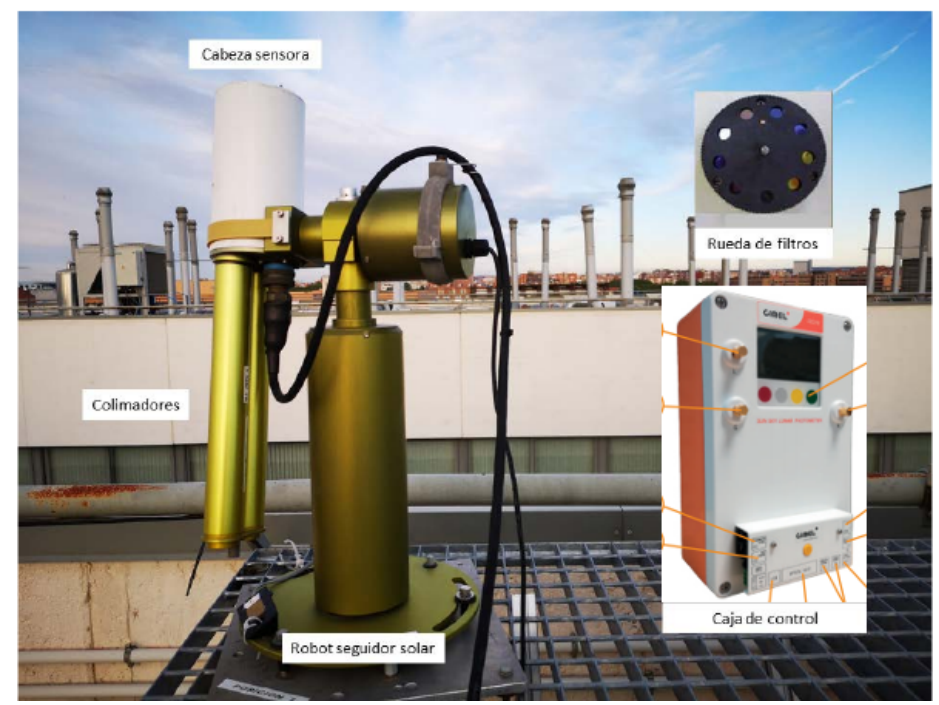

Figura 2.3: Esquema de cada uno de los elementos que componen el CIMEL CE318. En la imagen se puede ver en la parte izquierda la cabeza sensora montada en el robot seguidor. En la parte derecha se puede ver la rueda de filtros que está instalada en la cabeza y la caja de control del fotometro. Imagen obtenida de Guirado-Fuentes (2015)

\subsubsection{Familias de los fotómetros CIMEL}

El número de canales con los que cada instrumento realiza las medidas varía en función de la configuración del equipo. Existen múltiples configuraciones distintas de los fotómetros Cimel, pero todas ellas se pueden agrupar en las siguientes familias:

- Fotómetros estándar:

Surgen a principios de la de década de los 90, hasta 2002 en una versión analógica y posteriormente en su versión digital. Estos equipos realizan medidas de irradiancia solar en 8 canales $(340,380,440,500,675,870,935$ y 1020nm) y miden la radiancia de cielo en 4 canales $(440,675,870$ y $1020 \mathrm{~nm})$. Para realizar dichas medidas constan de dos detectores de Silicio destinados uno de ellos a realizar las medidas de irradiancia del Sol y de la radiancia del cielo en la aureola solar (se trata de la zona comprendida entre $2^{\circ}$ y $6^{\circ}$ de acimut con respecto al centro del disco solar) y el otro detector se destina a realizar las medidas de radiancia de cielo, de $6^{\circ}$ a $180^{\circ}$. La amplificación electrónica con la que se realiza cada una de las medidas puede ser modificada.

- Fotómetros extendidos:

Los primeros modelos datan de 2002. En estos equipos la configuración de los detectores cambia con respecto a los estándar, en este caso el equipo viene configurado 


\section{INSTRUMENTACIÓN Y DATOS}

con un detector de Silicio y otro de Arseniuro de Indio y Galio (InGaAs). Realizan medidas de irradiancia solar en 10 canales $(340,380$, 440, 500, 675, 870, 935, 1020, 1020 (InGaAs) y 1640nm) los canales comprendidos entre 340 y $1020 \mathrm{~nm}$ se realizan con el detector de Silicio, mientras que con el detector de InGaAs realiza medidas en $1020 \mathrm{~nm}$ (esta medida se realiza por ambos detectores con el mismo filtro) y en 1640nm. A parte, realiza medidas de radiancia de cielo en 6 canales $(440,500,675$, 870,1020 y 1640nm). Al igual que con las medidas al Sol, la medida a 1640nm la realiza con el detector de InGaAs y el resto de ellas con el de Silicio. La amplificación con la que se realiza cada una de las medidas puede ser modificada a través de la caja de control.

- Fotómetros triples:

A partir de 2013 se desarrolla esta nueva versión del instrumento, la más moderna hasta el momento. Estos equipos tienen una configuración de detectores y canales igual que los extendidos. La novedad con estos equipos es que son capaces de realizar medidas de irradiancia lunar, para obtener propiedades de los aerosoles durante la noche. Para dar este salto, la electrónica se ha mejorado sustancialmente, pero se ha conseguido un acuerdo entre la modernización del instrumento y la coherencia de las medidas con las versiones previas. Uno de los cambios que se ha realizado a nivel de electrónica en esta última versión es que la amplificación electrónica con la que se realiza cada medida no puede modificarse y viene fijada por defecto.

\subsubsection{Tipos de medidas}

Los fotómetros CIMEL realizan dos grandes grupos de medidas. Por un lado, existen las medidas de irradiancia de Sol, y también Luna en el caso de los fotómetros triples; por otro lado están las medidas de radiancia de cielo. De estas últimas existen varias geometrías de medida, cada una de ellas destinada a unos fines distintos.

Utilizando las medidas de irradiancia directa tanto solar como lunar, se puede obtener la atenuación de la radiación durante su paso a través de la atmósfera para calcular el AOD, como se explica en la sección 1.2 .

Para realizar las medidas de radiancia de cielo, el CIMEL utiliza distintas geometrías cada una definida en un escenario distinto. Estás geometrías son la de almucantar, la de plano principal y la de híbrido. Con cada una de estas geometrías se obtiene la cantidad de luz dispersada por los aerosoles en una serie de ángulos de scattering, como se describe a continuación: 
- El almucantar es una geometría en la que el ángulo cenital del instrumento permanece fijo e igual al ángulo solar cenital, mientras el ángulo acimutal varía entre $3.5^{\circ} \mathrm{y}$ $180^{\circ}$ con respecto al centro del disco solar. Este recorrido lo hace en ambas ramas simétricas, es decir, primero realiza la rama izquierda para, una vez finalizada barrer la rama derecha del cielo, siempre tomando el disco solar como posición de partida. Esta medida se realiza siempre que la elevación solar esté comprendida entre $38^{\circ}$ y $82^{\circ}$.

- El plano principal se realiza igualando el ángulo acimutal al mismo que el del Sol, y variando el ángulo cenital. Siguiendo este esquema, el fotómetro realiza medidas desde $6^{\circ}$ por debajo del disco solar hasta $150^{\circ}$ por encima. Esta medida se realiza cuando la elevación solar está comprendida entre $4^{\circ}$ y $79^{\circ}$.

- El escenario híbrido mezcla las geometrías del almucantar y del plano principal. La característica particular de este escenario es que varía los ángulos acimutales y cenitales hasta barrer un conjunto de ángulos de scattering fijos, hasta llegar a alcanzar el ángulo cenital de $75^{\circ}$, cuando empieza a barrer únicamente en el ángulo acimutal. Esta medida se realiza cuando la elevación solar está comprendida entre $4.5^{\circ}$ y $72^{\circ}$.

Una representación de estas medidas se puede ver en la Figura 2.4. donde también se muestran, sobre imágenes de una cámara todo cielo, los puntos de la bóveda celeste en los que se realiza cada una de las medidas.

Estas medidas se utilizan en los algoritmos de inversión, junto con las medidas de AOD, para obtener propiedades microfísicas y radiativas de los aerosoles (Dubovik and King, 2000; Dubovik et al., 2014) tales como el SSA o la distribución de tamaños de aerosoles.

En los fotómetros triples se ha incorporado también un nuevo escenario para medir la radiancia de cielo en la aureola solar que se llama Curvature Cross Sun. Este escenario realiza medidas en torno al Sol siguiendo la geometría del escenario híbrido, empezando en $3^{\circ}$ y acabando en $7.5^{\circ}$ cada $0.3^{\circ}$ en ángulos de scattering. La amplificación con la que se realiza este escenario es la misma que con la que se realizan las medidas de aureola. Este escenario se realiza en los modelos triples después de cada medida de AOD y es muy útil para detectar cirros y así realizar un filtrado de nubes en las medidas de AOD (ver sección 3.1).

\subsection{CELIS}

Para ayudar a la gestión de los datos producidos por los fotómetros de la red AERONET de los que el GOA-UVa es responsable se creó, entre 2008 y 2010, CÆLIS (www . caelis . u va.es). CÆLLIS surge en el momento en que el GOA-UVa requería una mejora profesional en su sistema de asimilación de datos. Esta mejora atendía a la gran cantidad de datos que 


\section{INSTRUMENTACIÓN Y DATOS}
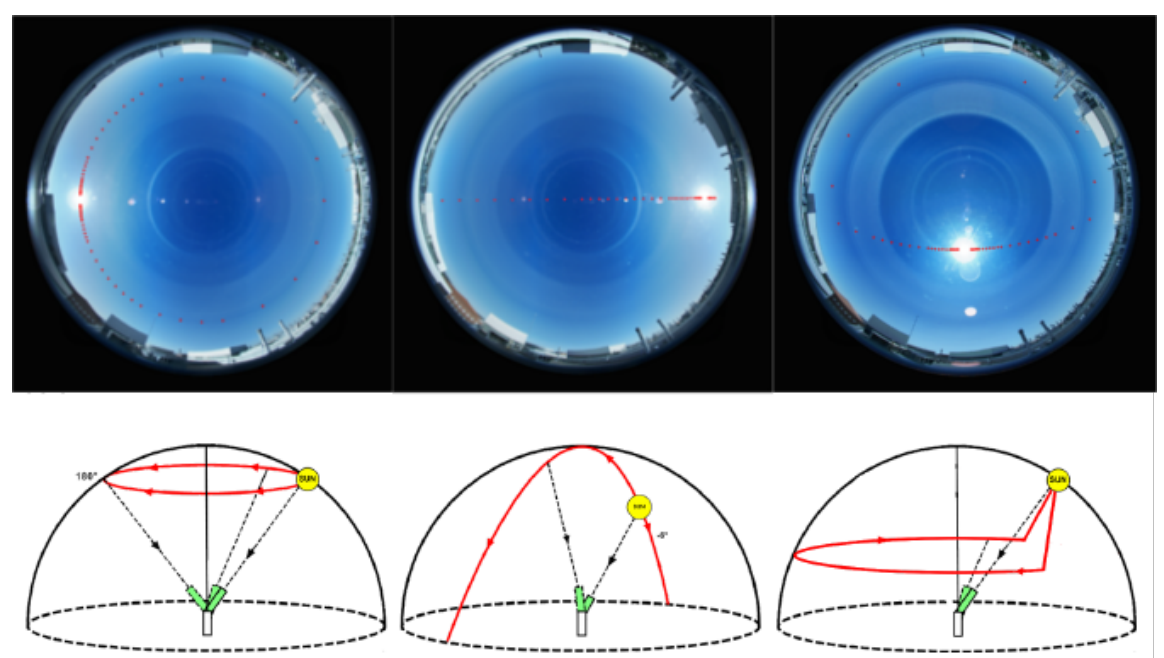

Figura 2.4: Geometrías de cada una de las medidas de radiancia de cielo que hace el Cimel . En la parte inferior se muestra un esquema de la geometría. La primera representa un almucantar, la segunda un plano principal y la tercera un híbrido. En la parte superior se muestra en puntos rojos los ángulos en los que se mide en cada geometría. Para estos ejemplos se ha usado la cámara todo cielo instalada en la Facultad de Ciencias de la Universidad de Valladolid con ángulos solares cenitales de $69.51^{\circ}, 70.38^{\circ}$ y $28.25^{\circ}$ respectivamente.

se recibían de continuo y la necesidad de generar productos a partir de esos datos, para los cuales no era suficiente con las herramientas convencionales que se venían utilizando. En ese instante se llega a la conclusión que disponer de las herramientas informáticas apropiadas facilita y mejora la calidad del trabajo a la hora de gestionar redes de instrumentos, como se describe en el trabajo doctoral Fuertes (2018).

CÆLIS es un sistema en continuo desarrollo que ha evolucionado en función de las necesidades del centro de calibración así como de la investigación del grupo. Dicha evolución siempre atiende a los mismos objetivos: (1) la gestión de la información generada por la red (base de datos y metadatos); (2) ayudar al mantenimiento de la red, lo que incluye un sistema de alarmas en tiempo real que advierte a los gestores y a los responsables locales de las estaciones sobre problemas en el funcionamiento de los instrumentos; y (3) Facilitar las tareas investigadoras al GOA-UVa y a los usuarios de la red, mediante la elaboración de productos que pueden ser consultados de manera flexible y potente.

CÆLIS está basado en una arquitectura cliente-servidor estando, a su vez, el servidor compuesto por tres módulos individuales encargados cada uno de ellos de unas tareas concretas. Como se puede ver en la Figura 2.5 el sistema está compuesto por una base de datos, un módulo de procesado en tiempo casi-real y un frontend (sistema de visualización).

La base de datos es el núcleo central de almacenamiento de todos los datos generados 


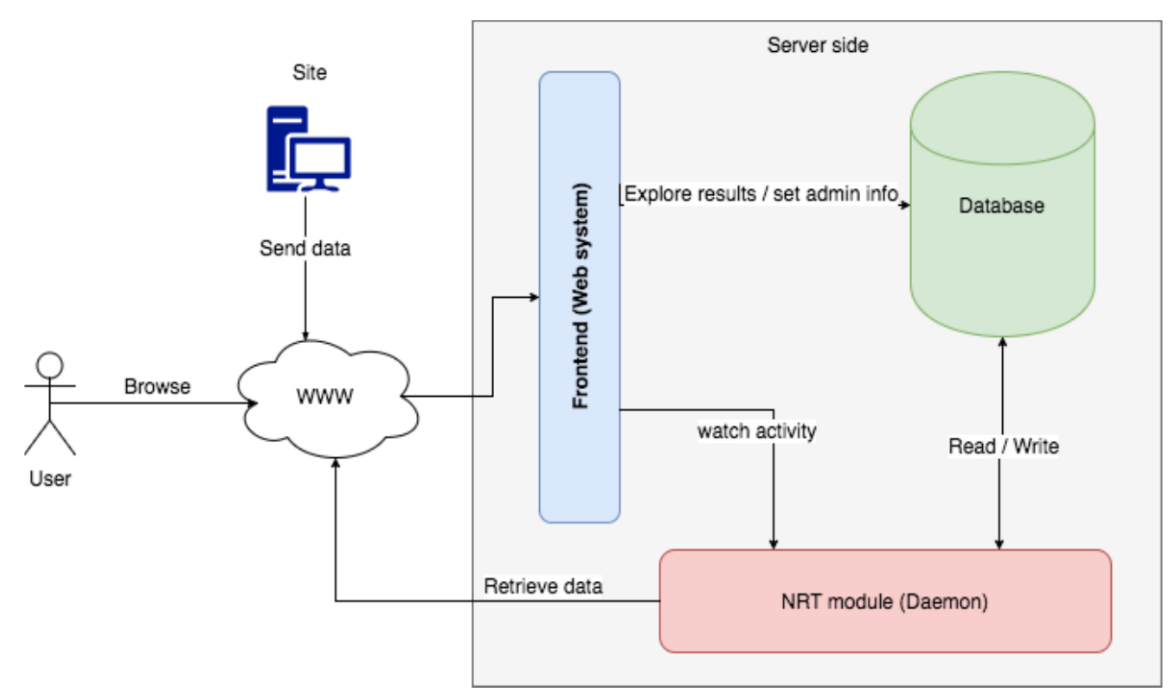

Figura 2.5: Diagrama de la arquitectura de CÆLIS. Las flechas indican dónde se inicia la acción (el flujo de datos es siempre bidireccional). Figura obtenida de Fuertes et al. (2018)

y recibidos en el sistema. En ella se almacenan la información bruta de cada medida así como toda la meta-información necesaria. Una vez procesados los datos, la salida de los distintos algoritmos es almacenada también en la misma base de datos. De esta forma, en un único contenedor, está accesible toda la información necesaria tanto para la comunidad científica como para los miembros del centro de calibración del GOA-UVa. Los datos se almacenan en esta base de datos acorde a tres capas lógicas diferenciadas y cada una de ellas con unos criterios de redundancia y trazabilidad distintos. La capa 0 se encarga de almacenar las medidas brutas generadas por los instrumentos, esta capa se caracteriza por ser completamente trazable y los datos almacenados en ella ser escasamente redundantes. En la capa 1 se almacenarán los productos directos que surgen de procesar las medidas brutas (radiancias o AOD por ejemplo), la redundancia de esta capa será algo mayor y la trazabilidad con las medidas brutas descenderá, centrándonos ya en el producto más que en la medida. En la capa 2 se almacenaran los productos derivados (alarmas, inversiones, clooud-screening, etc) esta capa la redundancia de datos será muy alta, para facilitar las consultas, mientra que la trazabilidad con las medidas brutas en ocasiones será nula.

Toda esta información está accesible en la base de datos, pero su interpretación es difícil para usuarios no expertos en estos sistema. Para hacer la información completamente accesible a un amplio rango de usuarios CÆLIS cuenta con un módulo de visualización (el módulo frontend). Este módulo, accesible a través de un portal web, representa de forma amigable toda la información almacenada en la base de datos. A su vez es el que utiliza el centro de calibración del GOA-UVa para evaluar el estado de cada uno de los instrumentos, así como 


\section{INSTRUMENTACIÓN Y DATOS}

los responsables de cada instrumento para visualizar los datos generados por sus instrumentos. Poder visualizar a través de este módulo tanto los datos brutos como los datos generados por los distintos procesados permite detectar posibles anomalías en el funcionamiento de los instrumentos que no serían posibles detectar sin estos procesados. Un ejemplo de una anómalia que es visible a través de este módulo es la que se puede ver en la Figura 2.6. Donde a partir del procesado del AOD y de los Langleys diarios, que se procesan en CÆLIS, se detecta una obstrucción en el caminio óptico a la hora de realizar la medida.

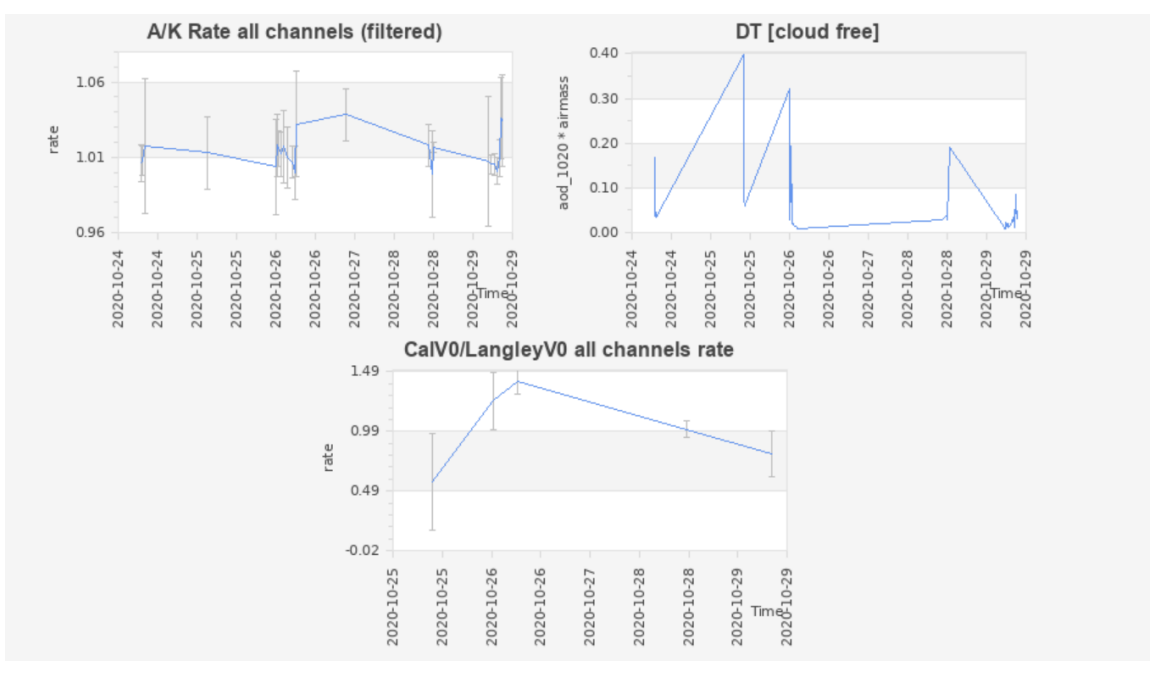

Figura 2.6: Módulo de visualización de CÆLIS que permite acceder a los datos procesados por el sistema para detectar anomalías en las medidas de los distintos instrumentos. Figura obtenida de www. caelis.uva.es

El tercero de los elementos que componen el sistema de CÆLIS es el módulo de procesado en tiempo casi-real. Este módulo procesa datos inmediatamente tras su llegada al servidor. Este servicio es que ha sido diseñado para que nuevos procesados puedan ser incluidos en él. Un ejemplo de esto es lo que se ha hecho con el AOD, tanto del día como de la noche, y con el filtrado de medidas afectadas por nubosidad (Cloud Screening). Una vez los nuevos procesados se incluyen en el servicio, éste garantiza ofrecer el resultado de los procesados en tiempo casi-real. De esta forma, si se crea un nuevo procesado de datos, se podrán construir una serie de alarmas que permitan identificar funcionamientos erróneos en los instrumentos. Así, con la incorporación de nuevos procesados, no solo se mejora en el conocimiento sobre los aerosoles atmosféricos, sino que también ayuda a que la información que se tiene sobre los aerosoles sea más fiable debido a la calidad con la que están hechos los productos procesados.

El módulo de procesado en tiempo casi-real se nutre de recursos externos que han de ser asimilados por CÆLIS. Para ello, CÆLIS almacenan en la base de datos información rela- 
tiva a espectros extraterrestres (solar y lunar), datos meteorológicos (presión), coeficientes de absorción de gases, etc, que se usan de forma común para todos los procesados que se realizan. Esta asimilación depende de la disponibilidad de cada uno de los recursos, pudiendo retrasarse con respecto a la hora prevista de ejecución y no ser inmediata. En caso de no estar disponible el recurso en el momento del procesado se utilizan datos estándar que, aunque su precisión sea menor, permiten tener un pre-procesado de datos que también aporta información de la medida. Para conocer con certeza la precisión de los datos externos que se han utilizado con cada medida, existe en CÆLLIS una serie de etiquetas (o flags) asociados a cada medida que indican, para cada recurso necesario, el nivel de precisión utilizado.

Con todo este sistema montado es relativamente sencillo incorporar nuevos instrumentos, como ya se ha hecho en ocasiones para realizar determinados estudios (Toledano et al. 2018). Bastaría con asimilar dentro de CÆLIS las medidas brutas del nuevo instrumento y ejecutar los algoritmos ya desarrollados. De esta forma, los productos obtenidos de los distintos instrumentos que estén incluidos, estarían generados de manera similar y su comparación sería independiente del procesado. La realización de los artículos expuestos en la sección 3 se ha basado en el uso de la herramienta CÆLLIS y la inclusión de nuevos productos en ella. 



\section{Resultados}

\subsection{Artículo 1: Daytime and nighttime aerosol optical depth implementation in CAELIS}

\subsubsection{Resumen y comentarios}

De acuerdo con lo descrito en la Introducción, una de las magnitudes fundamentales para el estudio de los aerosoles atmosféricos es el espesor óptico de aerosoles o AOD. Esta variable es útil para el control y monitorización de la calidad de las medidas que los fotómetros realizan, así como el estado de estos instrumentos. Por todo ello, es importante disponer de valores calculados de AOD de alta calidad y cuyo algoritmo de cálculo esté bien contrastado. Sin embargo, el cálculo de un AOD de calidad no es suficiente para los distintos problemas planteados, si no que además se necesita un algoritmo capaz de detectar los valores de AOD contaminados por nubes.Estas medidas no son aceptables para el estudio de los aerosoles y pueden llevar a resultados erróneos de no ser descartadas. En este marco, la herramienta CÆLIS, desarrollada para la gestión de las estaciones de la red AERONET, aporta soluciones homogéneas a estos problemas.

Si bien las ecuaciones para el cálculo del AOD están bien documentadas y son sencillas de procesar, en el cálculo del AOD entran en juego bastantes detalles que deben tenerse en cuenta. En esta sección se explica en detalle el proceso que se sigue en CÆLIS para obtener el AOD, dejando documentadas cúales son las fuentes auxiliares de datos que se utilizan durante el proceso. De la misma forma se explica el algoritmo que determina si los datos están contaminados o no por nubes (este algoritmo se conoce como Cloud Screening). 


\section{RESULTADOS}

Ambos algoritmos, tanto el del AOD como el del Cloud Screening, están basados en la Version 3 de AERONET.

Para demostrar la precisión y exactitud del algoritmo desarrollado en CÆLIS se ha comparado con la base de datos de AERONET. Con este fin, se han seleccionado 9 estaciones, pertenecientes al GOA-UVa y con características diferentes, durante los años 2016 a 2018 , lo que ha llevado a analizar más de 250000 medidas.

Para el caso del AOD, se han calculado las diferencias entre el AOD de CÆLIS y el de AERONET. Todas las diferencias obtenidas están por debajo del criterio U95 (WMO, 2005). La media de las diferencias están comprendidas entre $-1.3 \times 10^{-4}$ (para el AOD en $870 \mathrm{~nm}$ ) y $6.2 \times 10^{-4}$ (para el AOD en $380 \mathrm{~nm}$ ). La desviación estándar de las diferencias está comprendida entre $2.8 \times 10^{-4} 4($ en $675 \mathrm{~nm})$ y $8.1 \times 10^{-4}$ (en $\left.340 \mathrm{~nm}\right)$. Estos resultados demuestran la alta exactitud y precisión del algoritmo desarrollado implementado en CÆLLS.

La validación del algoritmo de Cloud Screening de CÆLLIS se ha realizado comparando los valores de AOD que el algoritmo de CÆLLIS no rechaza por nubes con los datos que llegan al nivel 1.5 de AERONET. Esta comparación ha dado como resultado que entorno al 99.9\% de los datos de AOD considerados como "sin nubes" por AERONET son calsificados de la misma manera también por el algoritmo de CÆLIS; de la misma manera, el $99.9 \%$ de los datos clasificados como "con nubes" en AERONET lo son también el CÆLIS.

Con estos resultados se puede asegurar que el algortimo de AOD y de Cloud Screening desarrollado en CÆLLIS cumple con las espectativas esperadas, proporcionando datos de AOD (y su filtrado de nubes) similares a los de AERONET, siendo este el AOD de referencia.

A continuación, se pueden leer todos los detalles en el artículo correspondiente.

\subsubsection{Daytime and nighttime aerosol optical depth implementation in CALIS}

Ramiro González ${ }^{1}$, Carlos Toledano ${ }^{1}$, Roberto román ${ }^{1}$, David Fuertes ${ }^{2}$, Alberto Berjón ${ }^{1,3,4}$, David Mateos ${ }^{1}$, Carmen Guirado-Fuentes ${ }^{1,3}$, Cristian Velasco-Merino ${ }^{1}$, Juan Carlos AntuñaSánchez ${ }^{1}$, Abel Calle ${ }^{1}$, Victoria E. Cachorro ${ }^{1}$, and Ángel M. de Frutos ${ }^{1}$

${ }^{1}$ Group of Atmospheric Optics, University of Valladolid (GOA-UVa), Valladolid, Spain

${ }^{2}$ GRASP-SAS, Remote Sensing Developments, Villeneuve D’Ascq, France

${ }^{3}$ Izaña Atmospheric Research Center, Meteorological State Agency of Spain (AEMET), Izaña, Spain

${ }^{4}$ TRAGSATEC, Madrid, Spain 


\subsection{Artículo 1: Daytime and nighttime aerosol optical depth implementation in CAELIS}

Correspondence: Ramiro González (ramiro@goa.uva.es)

Recived: 1 July 2020 - Discussion started: 22 July 2020

Revised: 18 September 2020 - Accepted: 28 September 2020 - Published:

Abstract The University of Valladolid (UVa, Spain) has manages a calibration center of the AErosol RObotic NETwork (AERONET) since 2006. The CÆLIS software tool, developed by UVa, was created to manage the data generated by AERONET photometers, for calibration, quality control and data processing purposes. This paper exploits the potential of this tool in order to obtain products like the aerosol optical depth (AOD) and Angström exponent (AE), which are of high interest for atmospheric and climate studies, as well as to enhance the quality control of the instruments and data managed by CÆLIS. The AOD and cloud screening algorithms implemented in CÆLIS, both based on AERONET version 3, are described in detail. The obtained products are compared with the AERONET database. In general, the differences in daytime AOD between CÆLIS and AERONET are far below the expected uncertainty of the instrument, ranging in mean differences between $-1.3 \times 10^{-4}$ at $870 \mathrm{~nm}$ and $6.2 \times 10^{-4}$ at $380 \mathrm{~nm}$. The standard deviations of the differences range from $2.8 \times 10^{-4}$ at $675 \mathrm{~nm}$ to $8.1 \times 10^{-4}$ at $340 \mathrm{~nm}$. The AOD and AE at nighttime calculated by CÆLIS from Moon observations are also presented, showing good continuity between day and nighttime for different locations, aerosol loads and Moon phase angles. Regarding cloud screening, around $99.9 \%$ of the observations classified as cloud-free by CÆLIS are also assumed cloud-free by AERONET; this percentage is similar for the cases considered cloudcontaminated by both databases. The obtained results point out the capability of CÆLIS as a processing system. The AOD algorithm provides the opportunity to use this tool with other instrument types and to retrieve other aerosol products in the future.

\subsubsection{Introduction}

Atmospheric aerosol particles contribute to climate forcing through their interactions with radiation and clouds, and its impact is still subject to large uncertainty (IPCC, 2014). Aerosol measurements are carried out worldwide in order to reduce these uncertainties using various techniques: active and passive remote sensing (from the ground and space) and in situ. Sun (and Moon) photometry is one of the most extended techniques for aerosol remote sensing; the main parameter provided by photometers is the aerosol optical depth (AOD), i.e., the extinction by aerosol particles in the entire atmospheric column. AOD is a proxy for the aerosol load in the atmosphere; its variation with wavelength, usually quantified by 


\section{RESULTADOS}

the Ångström exponent (AE), provides information about the size predominance of these particles (Angström, 1961).

Ground-based photometers use direct Sun (or Moon) spectral irradiance to derive AOD. It is calculated from these measurements using the Beer-Bouguer-Lambert law (Shaw, 1976). The AOD uncertainty depends on the photometer model, but it is usually small, about 0.010.02 in daytime. These measurements are therefore considered the "ground truth" for calibration and validation purposes.

Ground-based photometer networks provide long-term and near-real time aerosol data that are used for aerosol property monitoring, satellite and model calibration and validation purposes, and synergy with other instruments. These are the objectives of the Aerosol Robotic Network (AERONET; Holben et al. 1998), the most extended photometer network, but similar objectives are also pursued by the GAW-PFR network (Kazadzis et al., 2018b) and SKYNET (Takamura et al., 2004). The aerosol monitoring activity in the photometer networks relies on the standardization of instruments, calibration and processing (Holben et al. 1998; Wehrli, 2000). This is the case for AERONET, in which the standard instrument is the Cimel CE318 photometer. This is an automatic instrument that is able to perform direct Sun observations (and direct Moon in the latest version) and a number of sky radiance scans. Narrowband filters and two detectors ( $\mathrm{Si}$ and InGaAs) allow spectral measurements in the range 340-1640nm. The extinction measurements (Sun or Moon) are taken every 3-15 minutes, and consist of three measurements per spectral channel collected within 1 minute. These 'triplets' are the basic measurement for evaluation of the instrument stability and the identification of cloud contamination.

The calibration needed for AOD evaluation is the extraterrestrial signal of the instrument, which is normally derived using the Langley plot technique (Shaw, 1983) for reference instruments, or side-by-side comparison for field instruments. The reference instruments are calibrated at high altitude stations like Mauna Loa and Izaña (Toledano et al., 2018). Field instruments are calibrated at intercalibration sites. In the AERONET network, calibration facilities at GSFC/NASA(Greenbelt, USA), PHOTONS/LOA (Lille, France) and GOA/UVa (Valladolid, Spain) are used for this activity. The instruments are routinely calibrated and maintained to ensure data quality. The facilities at Lille and Valladolid are also part of the Aerosol, Clouds and Trace Gases Research Infrastructure (ACTRIS, www.actris.eu), a pan-European initiative to provide open and high-quality observations of those atmospheric constituents.

There is a need to evaluate the photometer data in real time and control large amounts of data generated by the network. Hence, in order to help in the management of the AERONET/ACTRIS calibration facility at Valladolid, a software tool called CÆLIS was developed 
(Fuertes et al. 2018). It provides tools for monitoring the instruments, processing the data in real time and offering the scientific community a new tool to work with the data. For this purpose, CÆLIS contains a database and a web interface to visualize raw data and metadata, provides processing of sky radiances and supports the monitoring of the instrument performance. This tool is capable of detecting several technical problems with the network instruments through an automatic warning system based on the CÆLIS metadata and products, which allows a quick response to detect and solve operation problems.

In this framework, the calculation of the AOD is important because several checks can be applied to the data to ensure the reliability of the measurements. Moreover, CÆLIS also intends to be a framework to facilitate research activities, with the AOD being a key product in present and future investigations. Therefore, the main objective of this paper is to develop and describe the implementation of the aerosol optical depth and cloud screening algorithms in CÆLIS.

The AOD product must be robust and operational: for example, it must work for any site and instrument configuration, even with incomplete or damaged raw data files, which it should adequately flag if it is the case. CÆLIS is focused on AERONET and the Cimel photometer simply because that is the framework of our calibration activity. And this is actually the best reference point that we have in order to validate the AOD algorithm. Therefore we will compare the results with those provided by the AERONET version 3 AOD algorithm (Giles et al. 2019), including the cloud screening, which is necessary because AOD can only be derived when the Sun or Moon is not obstructed by clouds.

We present the general framework for the AOD calculation (section 3.1.2.2) and then the daytime (solar) and nighttime (lunar) algorithms are described in detail (sections 3.1.2.3 and 3.1.2.4). The latter includes a novel correction (Román et al. 2020) that considerably improves the quality of the lunar retrievals. The cloud screening is described in section 3.1.2.5 and finally the algorithm results are compared with the AERONET database (section 3.1.2.6.

\subsubsection{General framework for AOD calculation}

The calculation of aerosol optical depth in CÆLLIS is intended to provide this parameter for a number of instruments, i.e., the photometers within the AERONET network that are calibrated at the University of Valladolid and routinely provide measurements to the CÆLIS system. They constitute an operational network with about 40 active sites that deliver data in near real-time. Therefore the algorithm needs to be robust and work in a large variety of circumstances, such any site location, different instrument types, incomplete ancillary information and with defective input data. 


\section{RESULTADOS}

The algorithm to calculate the aerosol optical depth is composed of two main parts. In the first part the algorithm searches in the database all the meta-information about the photometer at the specific date and time, such as calibration coefficients, location and filters. In the second part, the raw measurement data and the meta-information are used to calculate the AOD

Figure 3.1 shows the process followed to generate the AOD, and as can be observed, it requires a lot of ancillary information. All that information is being stored in the CÆLIS database. Each photometer on any particular date and time is linked in one deployment ('installation') with all that ancillary information. In this installation the information related to the beginning and ending dates when the photometer was deployed in one site, as well as the coordinates of the site, are stored. Once the photometer location is known, the next step is to know the specific instrument configuration. In this step all the information related with the instrument type ${ }^{1}$, which could change from one deployment to another, is needed in addition to information about the interference filters of the photometer, e.g. the central and nominal wavelength of the spectral channels and the specific gaseous and water vapor absorption coefficients for those wavelengths.

Then, the algorithm reads the photometer calibration (extraterrestrial signal at mean Earth-Sun distance) and the temperature correction coefficients. This information is provided by the Valladolid calibration facility to the AERONET database and is therefore identical to that used in the AERONET version 3 products. The calibration is then adjusted to the EarthSun distance for each observation date and time.

The ancillary information needed for the processing is the local pressure and the column of absorbing gaseous species taken into account: ozone, nitrogen dioxide, carbon dioxide and methane. A detailed description of how this information is obtained by CÆLIS for the specific date, time and location is provided in section 3.1.2.2.3. Three levels are established for the ancillary meteorological data: 1) meteorological data fields; 2) climatology; 3) standard atmosphere. This is also the hierarchy for the data usage. Therefore, a default value, as provided by a standard atmosphere model (for example pressure), will only be used in the case that the meteorological data fields or climatology table are not available. This approach is intended to provide the necessary ancillary information in a consistent and operational way across the network, even if some sites could provide more accurate values with colocated measurements. For absorbing gaseous species, we use a monthly climatology

\footnotetext{
${ }^{1}$ Three generations of Cimel photometers are nowadays used in AERONET: analog (starting 1992), digital (starting 2002) and "triple" (starting 2013) instruments (Toledano et al. 2018). Within these three families, several versions were developed: standard, extended, polarized, seaprism, etc. Thus a variety of Cimel instruments is in operation in AERONET.
} 


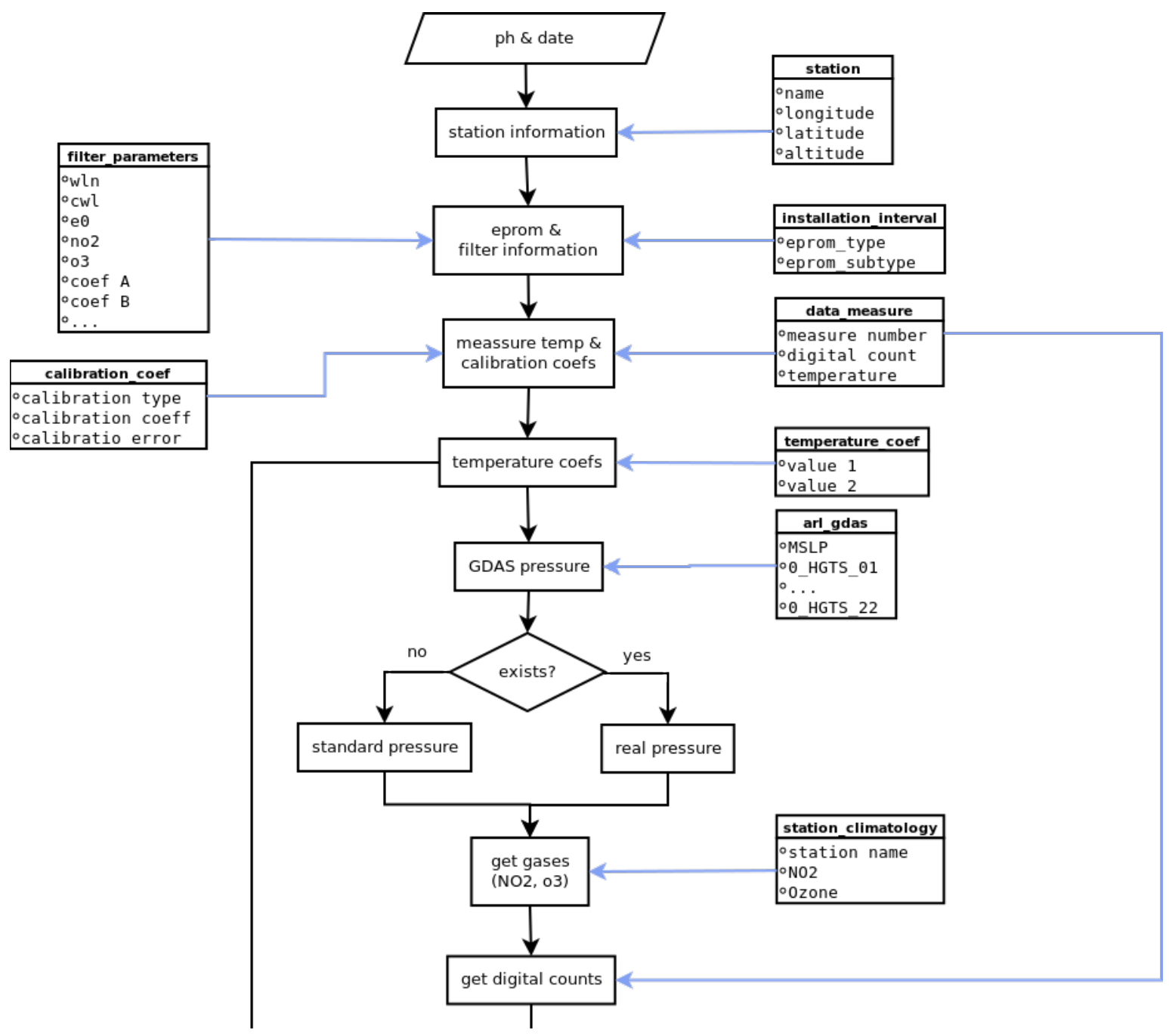

Figure 3.1: Flux diagram of the retrieval of necessary data to be used by the AOD algorithm. 


\section{RESULTADOS}

(see section 3.1.2.2.3). In the case that some station do not have data for a certain month, a seasonal mean (or annual, if necessary) is used instead.

At this point the first main part of the algorithm flow is concluded. A series of flags have been filled in relation to the obtained meta-information, and the algorithm enters the second part, in which the raw data on direct irradiance are processed. The workflow of the computation is shown in Figure 3.2 .

As already mentioned, CÆLIS stores all the data generated by the photometers that are calibrated at our facility. Therefore, the AOD algorithm only needs to get the raw data from the correct table of the database and use them to calculate the AOD for each measurement. This procedure must be repeated a number of times, which depends on the instrument type. In digital and triple Cimel photometers, equipped with 10 spectral channels, a total of 30 measurements are collected in each AOD observation. The three measurements per channel acquired over 1 minute (triplets) constitute the basic AOD measurement for each wavelength. A temperature correction is applied to these raw data according to the internal temperature recorded at the sensor head (see section 3.1.2.2.3 for details).

The total optical depth (TOD) can be computed using the Beer-Bouguer-Lambert law, as shown in section 3.1.2.3, and then the contributions of molecules and gaseous absorption for each wavelength are subtracted from the TOD in order to obtain the AOD. The precipitable water vapor column (PWV; section 3.1.2.3.2) is also derived from the photometer measurements using the 940nm channel; this PWV value is used to further correct the AOD at $1020 \mathrm{~nm}$ and 1640nm channels for (minor) water vapor absorption (Smirnov et al., 2004). The Ångström exponent is also calculated from the retrieved AOD values (section 3.1.2.3.2). Finally, the obtained AOD values with three observations per wavelength will be screened for cloud contamination (section 3.1.2.5).

\subsection{CALLIS database structure for AOD}

CÆLIS is composed of a relational database, a processing module and a web interface (Fuertes et al., 2018). As indicated above, in this database we can find all the information required to compute the AOD. Thanks to the deployment records (installations) in the database, we can link, for a specific date, all the physical and logical information about each particular instrument and how it is (or was) configured. That means we can access to the calibration coefficients of each spectral channel, the raw data and the filter specifications. All this information is stored in different tables of the database.

Similarly, after running the AOD algorithm, all the information generated will be stored in different tables of the database. Specifically two tables are designed to store all the AOD information. One table stores the information that is common for all the spectral channels, 


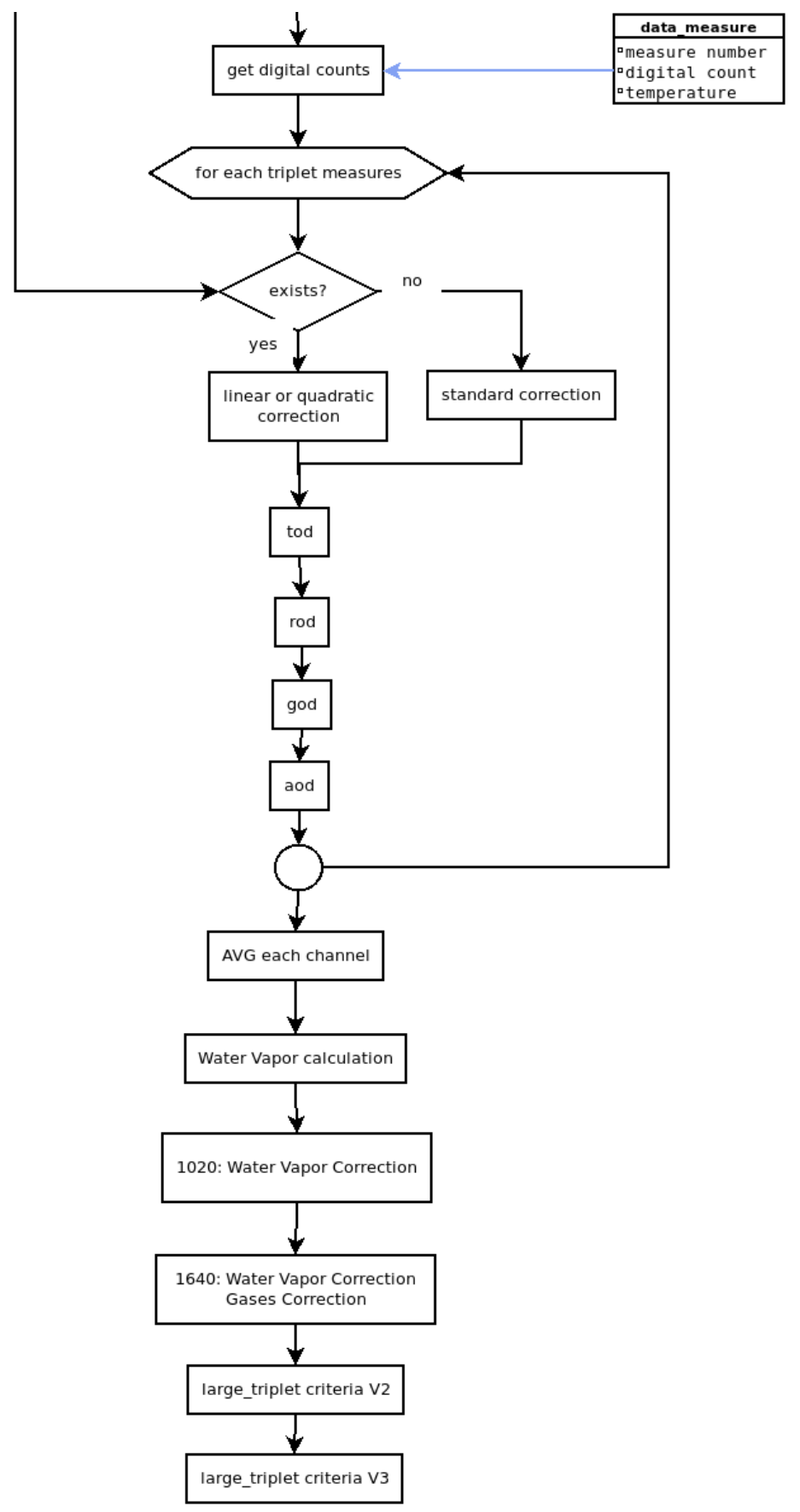

Figure 3.2: Flux diagram of the AOD computation in CÆLIS. 


\section{RESULTADOS}

including date and time, site, solar zenith angle, Earth-Sun distance, pressure and algorithm version. All the information stored in the common table is used to calculate the AOD for each channel. It also stores the derived Ångström exponent and PWV values. The second table stores the specific information for each spectral channel. That means we can find in this table the exact central wavelength of the filter, the calibration coefficient and the temperature correction of the channel, the specific absorption coefficient for gases, and the calculated values for the various components (total, Rayleigh, gaseous absorption and aerosol optical depth). According to the CÆLIS database structure (Fuertes et al., 2018), the AOD is a level 1 product ('direct product'); therefore, some redundant information is included in these tables in order to facilitate data extraction by users.

\subsection{Computing}

Thanks to the processing chain of CÆLIS, the near real time provision of AOD can be achieved. Every raw data file that is received in CÆLIS activates a set of triggers. First of all, the AOD algorithm runs between the first and last measurement included in the data file. Once a first version has been calculated, the system checks whether the AOD has been generated using a pressure value obtained by meteorological analysis (section 3.1.2.2.3) or if only standard pressure was available. If pressure from a meteorological analysis was not yet in the database, the system creates a new task (12 hours later) to reprocess the data until analysis pressure data are available.

Each file received by the system activates the task to calculate the cloud screening. This task runs the cloud screening algorithm for the full day, between 00:00 and 23:59 local time, even if the file does not cover the entire day. Once the AOD and the cloud screening have been calculated, the AOD can be used for further calculations. For instance, a task is triggered to calculate a set of quality control flags, some of them using the calculated AOD as input.

\subsection{Ancillary data}

\section{Global Data Assimilation System}

NOAA's Air Resource Laboratory runs a series of meteorological analyses and reanalyses; one of these is de Global Data Assimilation System (GDAS; see https : / www . nc dc.noaa.gov/data-access/model-data/model-datasets/global-dataassimilation-system-gdas). The GDAS is run four times per day, at 00:00, 06:00, 12:00 and 18:00 UTC. Model output is a grid with 1 degree resolution (360-181 latitudelongitude). This grid contains several meteorological fields at a set of pressure levels. 
GDAS data are stored in CAELIS every 6 hours for the purpose in calculating the local pressure for every site of the network. The pressure at the site elevation is calculated from a set of standard geopotential heights and interpolated in time. When pressure from GDAS is not available, the algorithm uses a standard pressure calculated with the site elevation, based on the US Standard Atmosphere. A flag indicates if the current AOD value is calculated with a standard pressure or using GDAS pressure.

This strategy to obtain pressure for all network sites is similar to the one followed by AERONET using NCEP/NCAR reanalysis data (Giles et al., 2019). Figure 3.3 presents the scatter plot between the pressure from CÆLIS and AERONET; the range of pressure values spans from $660 \mathrm{hPa}$ at the Teide site $(3570 \mathrm{~m}$ a.s.1.) up to $1030 \mathrm{hPa}$ at sea level sites. More than 180000 pressure values used for AOD observations are compared in this plot, showing a high correlation between the two databases. The differences between local pressure calculated by CÆLIS and AERONET are in general below $2 \mathrm{hPa}$ as shown in Figure $3.3 \mathrm{~b}$, where we observe a mean difference of $0.07 \mathrm{hPa}$ and standard deviation of about $1.1 \mathrm{hPa}$. Similar differences are found between GDAS pressure and actual pressure measurements (e.g. Abreu et al., 2012)).

The use of local pressure data is expected in CÆLIS for the future and will simply add another layer on top of the abovementioned hierarchy.
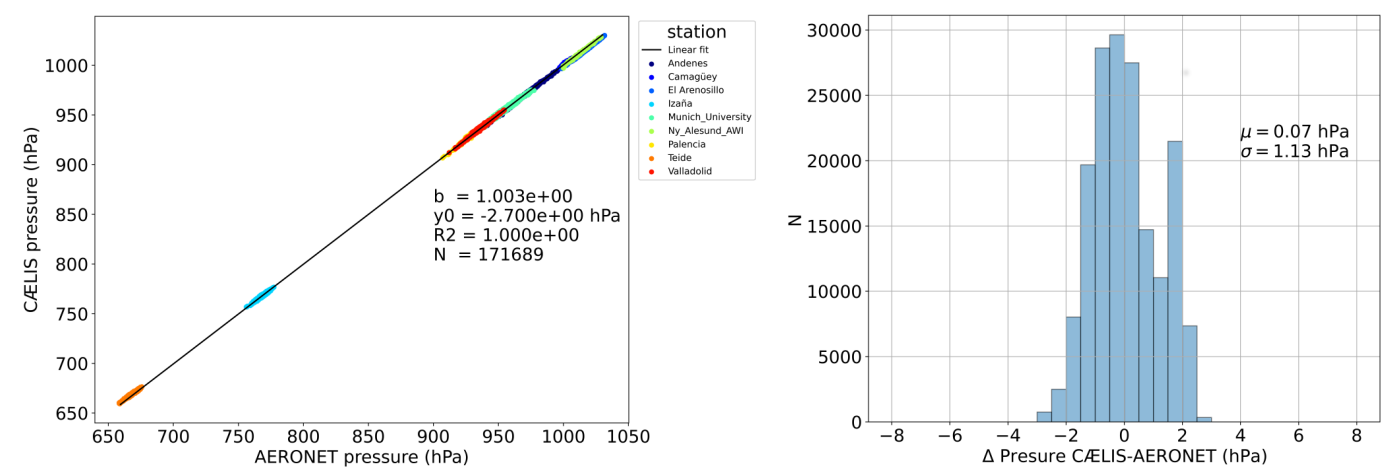

Figure 3.3: (a) CÆLIS atmospheric pressure as a function of AERONET atmospheric pressure for different stations. (b) Frequency histogram of the atmospheric pressure differences between CÆLIS and AERONET databases for all stations.

\section{Temperature correction}

The Cimel photometers are not stabilized in temperature during operation. In turn, the sensor head is equipped with a temperature sensor that allows correcting the measured signals with respect to a reference temperature of $25^{\circ} \mathrm{C}$. The correction is based on a laboratory 


\section{RESULTADOS}

characterization in a thermal chamber. Whenever a hardware element is changed in the photometer head (filter, detector, electronic card) a new thermal characterization is run for the instrument. The AERONET procedure for temperature characterization of the Cimel photometers is described in detail in Giles et al. (2019).

The information produced during these characterizations, i.e., the temperature correction coefficients for each wavelength above $400 \mathrm{~nm}$, is stored in the corresponding table of the CÆLLIS database. These are extracted by the AOD algorithm to correct raw signals according to the corresponding measurement temperature. The function to correct a signal with temperature is quadratic (i.e. two coefficients per channel). Whenever a characterization is not available for a particular instrument or channel, a default standard correction is applied, as produced by the AERONET analysis of historical filters, based on the filter manufacturer or type.

\section{Climatology tables}

The AOD algorithm needs to account for gaseous absorption at different wavelengths. Several gaseous species are taken into account: ozone, nitrogen dioxide, carbon dioxide and methane. The column amounts of $\mathrm{CO}_{2}$ and $\mathrm{CH}_{4}$ are considered constant, and a fixed value of optical depth scaled to local pressure is used to account for these absorptions in the $1640 \mathrm{~nm}$ channel (Giles et al., 2019). For $\mathrm{O}_{3}$ and $\mathrm{NO}_{2} \mathrm{C} Æ L I S$ uses climatology tables produced from satellite observations.

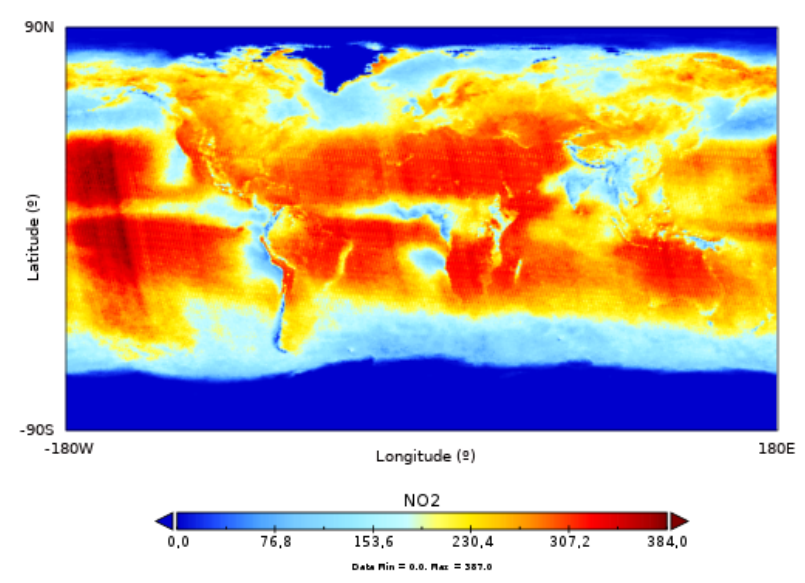

Figure 3.4: Climatology of $\mathrm{NO}_{2}$ (Dobson units $\times 10^{3}$ ) for the month of August. Data obtained from OMI version 3 (OMNO2d gridded, level 3) data between 2005 and 2017.

These climatology tables are monthly averages assigned to the 15th day of each month. The column abundance on other days is obtained by temporal interpolation. The $\mathrm{NO}_{2}$ climatology was obtained from OMI version 3 (OMNO2d gridded level 3, Krotkov et al., 2017) 
data between 2005 and 2017. An example of global $\mathrm{NO}_{2}$ for the month of August with this climatology can be seen in figure 3.4 . For the $\mathrm{O}_{3}$ climatology we use the multi-sensor reanalysis from GOME-2, OMI and SCIAMACHY sensors between 1978 and 2008 (van der A et al. 2010). An example, in this case the global values of $\mathrm{O}_{3}$ for the month of May, can be seen in figure 3.5, where higher ozone values are observed in the Northern Hemisphere, as expected in spring.

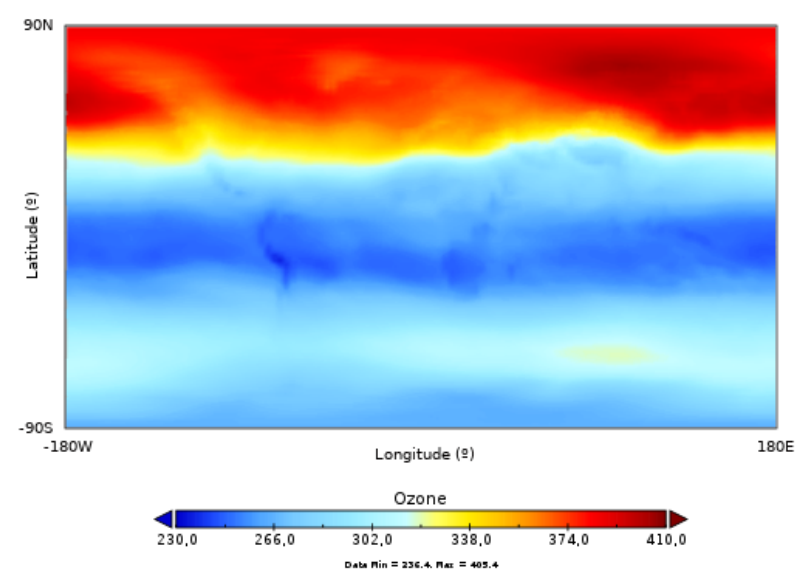

Figure 3.5: Climatology of $\mathrm{O}_{3}$ (Dobson units) for the month of May. Data obtained from the ulti-sensor-reanalysis from GOME-2, OMI and SCIAMACHY sensors between 1978 and 2008.

The comparison between the climatology tables used in CÆLIS and AERONET for $\mathrm{NO}_{2}$ and $\mathrm{O}_{3}$ is shown in figure 3.6 by means of frequency distributions of the differences. For $\mathrm{NO}_{2}$, the determination coefficient between CÆLIS and AERONET is high $\left(\mathrm{R}^{2}=0.978\right)$, and the mean of all differences (-0.04 DU) highlights a small underestimation by the CÆLIS database to AERONET climatology values with a standard deviation around 0.02 DU. In the case of $\mathrm{O}_{3}$, the scatter plot indicates very good correlation $\left(\mathrm{R}^{2}=0.995\right)$; the departure is typically within \pm 5 DU with a mean bias close to zero and a standard deviation of around $2.5 \mathrm{DU}$.

For calculation of the absorption optical depth of these species, the spectral absorption coefficients provided by Gueymard (1998) are applied, taking into account the spectral response functions of the individual filters. 

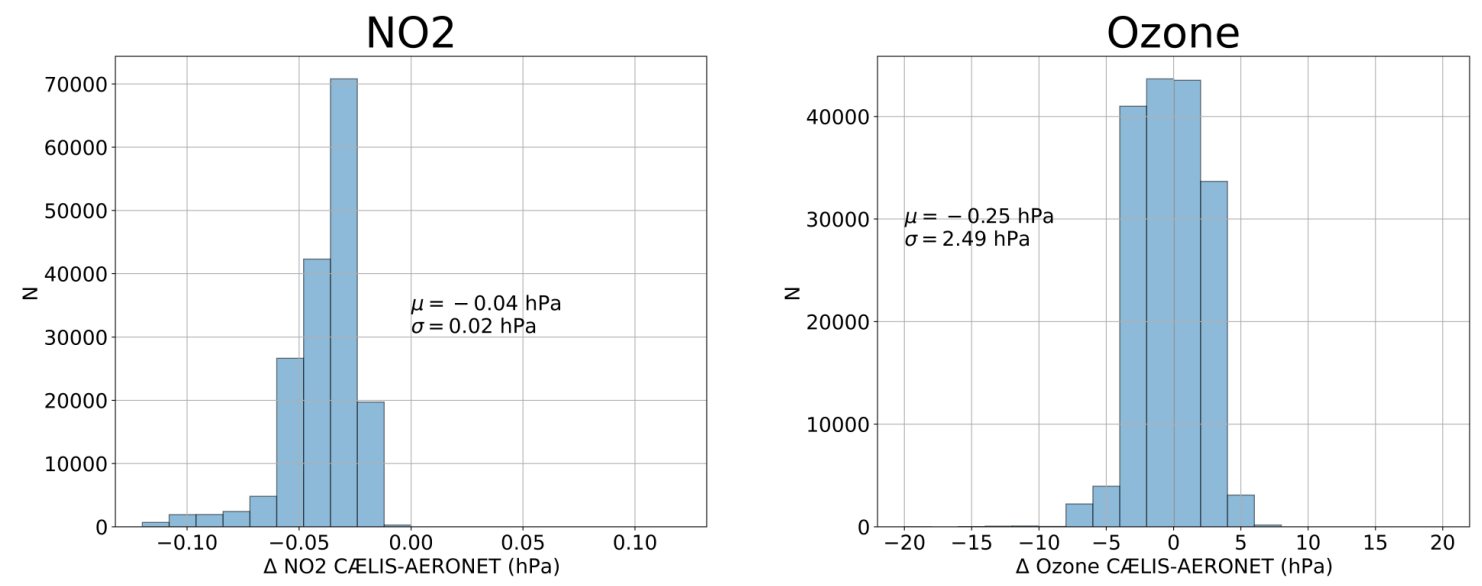

Figure 3.6: Frequency histogram of the differences between CÆLIS and AERONET databases for (a) $\mathrm{NO}_{2}$ climatology and (b) $\mathrm{O}_{3}$ climatology. Data in Dobson units (DU).

\subsubsection{Direct Sun algorithm}

\subsection{Aerosol optical depth}

The basic equation for aerosol optical depth calculation is the Beer-Bouguer-Lambert law (Cachorro et al., 1987; Shaw, 1976). In practice, this equation is applied to the raw instrument signal at a given wavelength that is measured at ground level $(V)$ and the signal that the photometer would have at the top of the atmosphere $\left(V_{0}\right)$ (equation 3.1 ):

$$
V(\lambda)=V_{0}(\lambda) \cdot R^{-2} \cdot e^{-\tau(\lambda) \cdot m}
$$

In this equation $R$ is the Earth-Sun distance in astronomical units, $m$ is the optical air mass that indicates the relation between extinction in the vertical column and that in the measurement (slant) path, thus related to the zenith angle of the target (Sun, Moon, star), and $\tau$ is the TOD. The aerosol optical depth can be then derived by subtracting the contribution to extinction by all other atmospheric components: scattering by molecules (Rayleigh scattering) and absorption by gases at a given wavelength.

The voltage signal $(V)$ has a temperature correction following equation 3.2. $C_{1}$ and $C_{2}$ are the coefficients for the thermal characterization that are stored in the database, and $T$ is the temperature given by the sensor head during the measurement.

$$
V=V^{\prime} /\left(1+C_{1}(T-25)+C_{2}(T-25)^{2}\right)
$$

An absolute calibration (given by $V_{0}$ ) is required for AOD retrieval. In order to obtain the top-of-atmosphere instrument signal the Langley plot method can be applied (Shaw, 1983; 
Toledano et al., 2018) or the calibration can be transferred from a reference instrument by side-to-side comparison (Holben et al., 1998). This calibration is supposed to be constant over time except for the Earth-Sun distance variations. A linear interpolation between preand pos-deployment calibration factors is applied.

Different air mass factors $m$ are taken into account for the various species; the reason behind this is the different vertical distribution of the gases $\left(\mathrm{O}_{3}\right.$ is mainly stratospheric, $\mathrm{CO}_{2}$ is uniformly mixed). Hence equation 3.1 can be rewritten as

$$
V(\lambda)=V_{0}(\lambda) \cdot R^{-2} \cdot e^{-\left[\tau_{a}(\lambda) \cdot m_{a}+\tau_{R}(\lambda) \cdot m_{R}+\tau_{g}(\lambda) \cdot m_{g}\right]}
$$

where the 'a' subscript stands for aerosol, 'R' for Rayleigh and 'g' for gases. Finally, the aerosol optical depth $\left(\tau_{a}\right)$ can be directly calculated from equation 3.3 by:

$$
\tau_{a}(\lambda)=-\frac{1}{m_{a}} \cdot\left[\ln \left(\frac{V(\lambda)}{V_{0}(\lambda) R^{-2}}\right)-\tau_{R}(\lambda) \cdot m_{R}-\tau_{g}(\lambda) \cdot m_{g}\right]
$$

The gaseous absorptions considered in the processing are the $\mathrm{O}_{3}, \mathrm{NO}_{2}, \mathrm{H}_{2} \mathrm{O}, \mathrm{CO}_{2}$ and $\mathrm{CH}_{4}$. The air mass for molecular (Rayleigh) scattering $m_{R}$ is taken from Kasten and Young (1989), whereas the Rayleigh optical depth is taken from the Bodhaine et al. (1999) formula and weighted with local pressure. The $\mathrm{O}_{3}$ air mass is taken from Komhyr et al. (1989). For aerosol and $\mathrm{NO}_{2}, \mathrm{C} Æ L I S$ uses $m_{R}$, and for water vapor $\left(m_{w}\right)$ the formulation given by Kasten (1965). The $\mathrm{CO}_{2}$ and $\mathrm{CH}_{4}$ optical depths (1640nm wavelength) are taken as fixed values of 0.0087 and 0.0047 respectively, corrected by local pressure (Giles et al., 2019). The solar zenith angle used in the air mass calculations is computed following Michalsky (1988).

\subsubsection{2 Ångström exponent \& precipitable water vapor}

Once the spectral AOD has been calculated, the precipitable water vapor and the Ångström exponent can be calculated. The AE is defined as the negative slope of a linear regression between the logarithm of AOD and the logarithm of the wavelength (in microns) in a defined spectral range. Two AEs are calculated: AE(440-870) for AOD between 440nm and 870nm and $\mathrm{AE}(380-500)$ for the range $380 \mathrm{~nm}$ to $500 \mathrm{~nm}$. AE is expected to be different in the different spectral ranges and it depends on the aerosol type (Eck et al., 1999; O'Neill et al. 2001; Vergaz et al., 2005).

The spectral channel that provides the optical depth in the 940nm water vapor absorption band is used to calculate the PWV. In this channel extinction is produced by aerosol and molecules as well as water vapor absorption. Therefore, CÆLIS first estimates the AOD at that wavelength as the extrapolation from $\operatorname{AOD}(870 \mathrm{~nm})$ and $\mathrm{AOD}(675 \mathrm{~nm})$ using the Ångström 


\section{RESULTADOS}

power law in that particular region. Then, CÆLIS follows the methodology described by Schmid et al. (1996), which requires specific characterization of the 940nm filter function of the photometer. This is based on a series of radiative transfer simulations that provide $a$ and $b$ coefficients, unique for each filter, that are used to model water vapor transmittance $T_{w}$ in the band for the photometer:

$$
T_{w}=\exp \left[-a\left(m_{w} u\right)^{b}\right]
$$

Where $u$ is the water vapor abundance and $\mathrm{m}_{w}$ the corresponding air mass. Taking all this into account, $u$ can be finally derived from the photometer signal in the $940 \mathrm{~nm}$ channel as:

$u=\frac{1}{m_{w}}\left(\frac{\ln T_{w}}{a}\right)^{1 / b}=\frac{1}{m_{w}}\left(\frac{-\ln V(940)+\ln V_{0}(940)-\tau_{R}(940) \cdot m_{R}-\tau_{a}(940) \cdot m_{a}}{a}\right)^{1 / b}$

The calibration factor (extraterrestrial signal) for the $940 \mathrm{~nm}$ channel is also performed during the routine calibrations together with the aerosol channels.

\subsubsection{Direct Moon algorithm for AOD}

The main difference between lunar and solar photometry is that the Moon reflects solar irradiance instead of emitting visible light by itself. This fact means that extraterrestrial lunar irradiance significantly changes, mainly with the Moon phase angle (MPA), even during one single night. Hence, accurate knowledge of the extraterrestrial lunar irradiance is needed for lunar photometry purposes. To this end, CÆLIS computes for each observation the extraterrestrial lunar irradiance at several wavelengths following the method of the RIMO model (ROLO Implementation for Moon's Observation; Barreto et al. (2019)), which is an implementation of the ROLO (RObotic Lunar Observatory) model (Kieffer and Stone, 2005), making use of the SPICE Toolkit (http://naif.jpl.nasa.gov/naif/toolkit.html) (Acton et al., 2018, Acton, 1996). After that, these lunar irradiance values are multiplied by a correction factor proposed by Román et al. (2020), which depends on MPA and wavelength. Following the Beer-Bouguer-Lambert law, the AOD can be calculated as follows (Barreto et al. 2013):

$$
\tau_{a}(\lambda)=\frac{\ln [\kappa(\lambda)]-\ln \left[V(\lambda) / I_{0}(\lambda)\right]-\tau_{g}(\lambda) \cdot m_{g}-\tau_{R}(\lambda) \cdot m_{R}}{m_{a}}
$$

where $\kappa$ is the calibration coefficient for an effective $\lambda$-wavelength, $I_{0}$ is the corrected extraterrestrial lunar irradiance at the same effective wavelength, $V$ is the photometer signal 
at the channel of the effective $\lambda$ wavelength and (m) values are the optical air masses calculated by the Kasten formula (Kasten and Young, 1989) using the Moon zenith angle (MZA) as input.

The AOD can be calculated at nighttime using equation 3.7 if the calibration coefficient $\kappa$ is known. In this work $\kappa(\lambda)$ is calculated by the so-called gain calibration method Barreto et al., 2016). This method consists of transferring the solar calibration to the lunar channels. The detectors are the same for Sun and Moon direct irradiance measurements in the Cimel; but, in order to reach a higher signal range, the Moon signal is electronically amplified by a gain factor, $G$, with a nominal value of $4096\left(2^{12}\right)$. Taking into account the fact that the only difference between Sun and Moon measurements is in this gain factor, the Sun calibration can be transferred to the Moon channels:

$$
\kappa(\lambda)=\frac{V_{0}(\lambda)}{E_{0}(\lambda)} \cdot G
$$

where $V_{0}(\lambda)$ is the Sun calibration coefficient and $E_{0}(\lambda)$ the extraterrestrial solar irradiance (Wehrli, 1985), both at the $\lambda$ wavelength. The gain calibration is simpler and it is not dependent on the RIMO (or other lunar irradiance model) and it only requires the calibration of the solar channels, which is routinely provided for AERONET instruments. Hence, CÆLLIS calculates AOD at nighttime using the stored $V_{0}$ values and equations 3.7 and 3.8 . The UV channel of $340 \mathrm{~nm}$ is not considered due to the low Moon signal recorded by the photometer at these channels, which implies a low signal-to-noise ratio. More details about the correction applied to the RIMO values and the methodology of AOD calculation can be found in Román et al. (2020).

\subsubsection{Cloud screening}

Global photometer networks like AERONET run hundreds of sites equipped with automatic instruments, that measure continuously. AOD retrieval requires that the Sun is not obstructed by clouds therefore, an automated cloud screening algorithm is required to remove cloudcontaminated AOD data, which in general are higher, present higher time variability and show lower spectral dependence than aerosol data. Many algorithms have been published in the literature, in many cases closely tied to the instruments in particular, although many common principles are frequently used: the temporal variability at different timescales, either on the raw signals or the computed AOD, and the analysis of spectral variation (Harrison et al. 1994; Khatri and Takamura, 2009; Smirnov et al., 2000; Wehrli, 2008). Recently, AERONET improved the cloud screening algorithm with several significant changes, including the addition of aureole radiance checks for detection of thin cirrus clouds (Giles et al., 2019). 


\section{RESULTADOS}

A cloud screening procedure is therefore needed in CÆLIS. Given the extensive tests with large data sets performed by Giles et al. (2019) and the improvements shown with respect to the previous algorithm, we have tried to reproduce this algorithm for Cimel photometers as a first step for CÆLIS.

The first step of the algorithm is to determine whether the Sun triplet collected is a valid measurement for AOD computation. In this sense, a minimum signal must be achieved in the measurement in order to guarantee that photometer is pointing to the Sun (or Moon), i.e. more than 100 counts in the infrared channels ( 870 and $1020 \mathrm{~nm}$ ). In addition, if any raw signal is lower than the extraterrestrial signal (calibration factor) divided by 1500 , which means total optical depth multiplied by an air mass of about 7, then the corresponding channel is rejected. Moreover, if the variability of the triplet signal (calculated as the root mean square over the mean) is larger than $16 \%$ in any channel, then the full observation is rejected.

The observations that qualify for AOD computation are then checked for AOD variability. Initially all observations are considered 'cloud-free'. They will be flagged as cloudy if the triplet variability (maximum - minimum AOD) is larger than 0.01 (or $0.015 \cdot \tau_{a}$, whichever is greater) for 675,870 , and $1020 \mathrm{~nm}$ channels, simultaneously. If all three channels exceed this threshold, then the measurement is labelled a 'large triplet'. From this point on, a number of checks are done by the algorithm, that can result in the remaining cloud-free triplets being flagged as cloudy. The label will indicate which check was activated. The first checks are related to quality control:

- If the air mass is larger than 7, then we apply the label 'airmass_range'.

- We check that the Ansgtröm exponent is within the interval [-1, 4]. Otherwise the data are not realistic and we apply the label 'Angstrom_range'.

Then the set of measurement points within a local day (sunrise to sunset) are analyzed together. Whenever new data are received within a certain day, this part of the algorithm will run for all the data available for that day.

- All cloud-free observations of an entire day are labeled potential_measurements when the number of remaining cloud-free observations is fewer than three in the day, or $10 \%$ of the potential measurements attempted by the photometer in that day.

- The temporal variability of AOD at $500 \mathrm{~nm}$ is calculated for each pair of consecutive remaining cloud-free observations; the observation with the largest measurement in the pair is assumed to be cloud-contaminated and labeled smoothness_criterion if the difference is larger than 0.01 per minute. This process is iterative and continues until 


\subsection{Artículo 1: Daytime and nighttime aerosol optical depth implementation in CAELIS}

no further data are classified as cloud-contaminated by this criterion or the number of data is less than 3 or $10 \%$ of the potential measurements, as indicated above.

- The curvature check for aureole radiance is then performed, as described by Giles et al. (2019). This is a novel approach that takes advantage of the Cimel photometer to measure solar aureole radiances, and it is intended to detect thin cirrus clouds. For this purpose, the curvature of the aureole radiance $(1020 \mathrm{~nm})$ vs. scattering angle is analyzed. If this flag is activated, then the triplet and all other triplets within 30 minutes (or within 2 minutes for Cimel CE318-T instruments) are flagged curvature_check.

- If an observation is distant by more than $1 \mathrm{~h}$ from any other cloud-free measurement and it presents an $\mathrm{AE}(440-870)$ value below 1.0, then this point is flagged as stand_alone.

- In the case that the standard deviation $(\sigma)$ of AOD at $500 \mathrm{~nm}$ of the cloud-free remaining points in the day is larger than 0.015 , then the observations that exceed mean $\pm 3 \sigma$ in AOD or AE are labeled 3-sigma.

A final step is done to recover observations with high spectral dependence, in the case that AOD (870nm) is larger than 0.5 and the Ångström exponent $(675-1020 \mathrm{~nm})$ is larger than 1.2. This prevents the removal of very high aerosol loading cases (occasionally with high temporal variability) due to biomass burning smoke and urban pollution (Giles et al., 2019; Smirnov et al. 2000). The label applied in this case is 'restoration' and it is equivalent to cloud-free, although very few data in our subset fulfill this condition.

All flags mentioned above result in the measurement point not being considered cloud_free, and allow us to identify in the database the reason for the rejection. Thus, we can query the database for cloud-free data at a certain site and during a certain period, but we can also analyze the cloud-screened data and discriminate for any specific check.

The full scheme as it has been described is applied to solar AOD data. For lunar observations, we have maintained the same analysis and thresholds, except for the aureole radiance check that cannot be performed at night. Further testing is needed to possibly refine the cloud-screening algorithm for nighttime.

\subsubsection{Validation of the AOD algorithm}

The photometer data that CÆLIS is currently processing for AOD, are all produced by $\mathrm{Ci}$ mel photometers belonging to AERONET. CÆLIS uses the same raw data and calibration. Moreover, AERONET is a global reference for AOD monitoring and its data are widely used by the scientific community dealing with aerosol, satellite validation and models. Therefore 


\section{RESULTADOS}

the most logical approach for validation of the CÆLIS AOD implementation is to compare it with the one produced by the AERONET version 3 direct Sun algorithm (Giles et al., 2019). This comparison is provided in section 3.1.2.6.2. The performance of the cloud screening algorithm for this daytime AOD is given in section 3.1.2.6.4. As for the nighttime (unar) algorithm, section 3.1.2.6.3 includes an analysis of the performance at several sites and Moon phases, but it is not compared to the AERONET processing because the lunar-derived AOD in AERONET is still marked as a provisional product.

\subsection{Data set for validation}

In Table 3.1 we summarize the data set that has been selected for AOD validation. It comprises 2 years of data for nine sites, with about 180000 AOD observations (triplets) collected with Cimel photometers.

The site list includes two high-mountain observatories used for Langley plot calibration of the reference instruments: Izaña and Teide (Toledano et al., 2018). The AOD is very low in these locations; therefore they are very suitable for a detailed comparison. We have also included a rural continental site (Palencia), our calibration site at Valladolid (small city and continental climate), an urban site (Munich), a coastal site (El Arenosillo), a Caribbean site (Camagüey), and the Arctic sites Andenes and Ny-Ålesund. Thus, we have tried to cover several aerosol types and ambient conditions in order to test the robustness of the algorithm.

Another important aspect of the subset is the variety of Cimel photometer types. We have covered all generations of Cimel instruments (analog, digital and triple) and multiple versions (see Table 3.1). This feature involved considerable work to ensure a flexible enough algorithm and adequate database construction, so that all data can be consistently processed. In turn, we expect this experience will be of help in the addition of new photometer types to CÆLIS.

Thus, we have analyzed a large amount of data to have statistical strength in the comparison and cover multiple situations. The data set is used for validation of the daytime (solar) algorithm. This data set will also be used for cloud screening comparison (section 3.1.2.6.4), in which a variety of climate conditions is also crucial.

\subsection{Daytime AOD validation}

The AOD obtained with direct the Sun algorithm has been compared for the abovementioned set of Cimel data. Identical raw data, calibration coefficients and temperature correction factors are used; therefore the differences can only be attributed to the algorithm and the ancillary data sources. 
Table 3.1: List of Sun photometers used during the validation study. The analyzed period for all sites spans from 01 January 2016 to 31 December 2017.

\begin{tabular}{|l|cccc|}
\hline \hline \multicolumn{1}{|c|}{ Site } & No. ph. & From (yyyy-mm-dd) & To (yyyy-mm-dd) & Ph. type \\
\hline \hline \multirow{2}{*}{ Andenes } & No. 904 & $2016-01-01$ & $2016-11-20$ & Triple - extended \\
& No. 789 & $2016-11-21$ & $2017-12-31$ & Triple - extended \\
\hline Camagüey & No. 425 & $2016-01-10$ & $2016-08-20$ & Digital - extended \\
\hline \multirow{2}{*}{ El_Arenosillo } & No. 640 & $2016-05-10$ & $2017-04-09$ & Triple - extended \\
& No. 640 & $2017-07-20$ & $2017-12-31$ & Triple - extended \\
\hline Izaña & No. 244 & $2016-01-01$ & $2017-12-31$ & Digital - extended \\
\hline \multirow{3}{*}{ Munich_University } & No. 198 & $2016-01-01$ & $2016-05-17$ & Analog - standard \\
& No. 600 & $2016-05-18$ & $2017-09-06$ & Triple - dual polar \\
& No. 600 & $2017-11-14$ & $2017-12-31$ & Triple - dual polar \\
\hline Ny_ÅlesundAWI & No. 904 & $2017-06-01$ & $2017-12-31$ & Triple - extended \\
\hline \multirow{5}{*}{ Palencia } & No. 243 & $2016-01-01$ & $2016-10-18$ & Analog - standard \\
& No. 788 & $2016-10-19$ & $2017-03-09$ & Triple - extended \\
& No. 424 & $2017-03-10$ & $2017-05-18$ & Digital - extended \\
& No. 425 & $2017-05-19$ & $2017-07-05$ & Digital - extended \\
& No. 243 & $2017-07-06$ & $2017-11-07$ & Analog - standard \\
& No. 788 & $2017-11-08$ & $2017-12-31$ & Triple - extended \\
\hline \multirow{2}{*}{ Teide } & No. 790 & $2016-05-17$ & $2016-11-11$ & Triple - extended \\
& No. 790 & $2017-05-19$ & $2017-11-09$ & Triple - extended \\
\hline \multirow{5}{*}{ Valladolid } & No. 788 & $2016-01-01$ & $2016-05-03$ & Digital - extended \\
& No. 627 & $2016-05-04$ & $2016-10-09$ & Digital - extended \\
& No. 942 & $2016-10-10$ & $2017-03-21$ & Triple - extended \\
& No. 627 & $2017-03-22$ & $2017-07-24$ & Digital - extended \\
& No. 942 & $2017-07-25$ & $2017-12-31$ & Triple - extended \\
\hline \hline
\end{tabular}

The criterion for AOD comparison between two instruments recommended by the World Meteorological Organization is the so-called U95 threshold (WMO, 2005), defined as

$$
U 95= \pm(0.005+0.010 / m)
$$

Where $m$ is the air mass. As can be seen in the following analysis, the boundaries of U95 are in general too large for our case, in which we compare algorithms rather than instruments. But it is a good reference as a starting point because it is commonly used in this kind of studies (e.g. Cuevas et al. (2019)).

The AOD comparison for the different wavelengths is shown in Figure 3.7. The differences are computed as CÆLIS-AERONET and they are plotted as a function of air mass. The U95 boundary is also depicted, as is the maximum and minimum difference for each channel. The largest differences are observed for the $340 \mathrm{~nm}$ and the smallest for the $870 \mathrm{~nm}$ channel, with $5.1 \pm 8.2 \times 10^{-4}$ and $-1.3 \pm 3.4 \times 10^{-4}$, respectively. This result is expected because no gaseous corrections are needed in the $870 \mathrm{~nm}$ channel; therefore, the differences can only be caused by different values of the solar zenith angle and the derived air mass. This is an important result because it indicates that the ancillary data play a key role in the different processing schemes. 

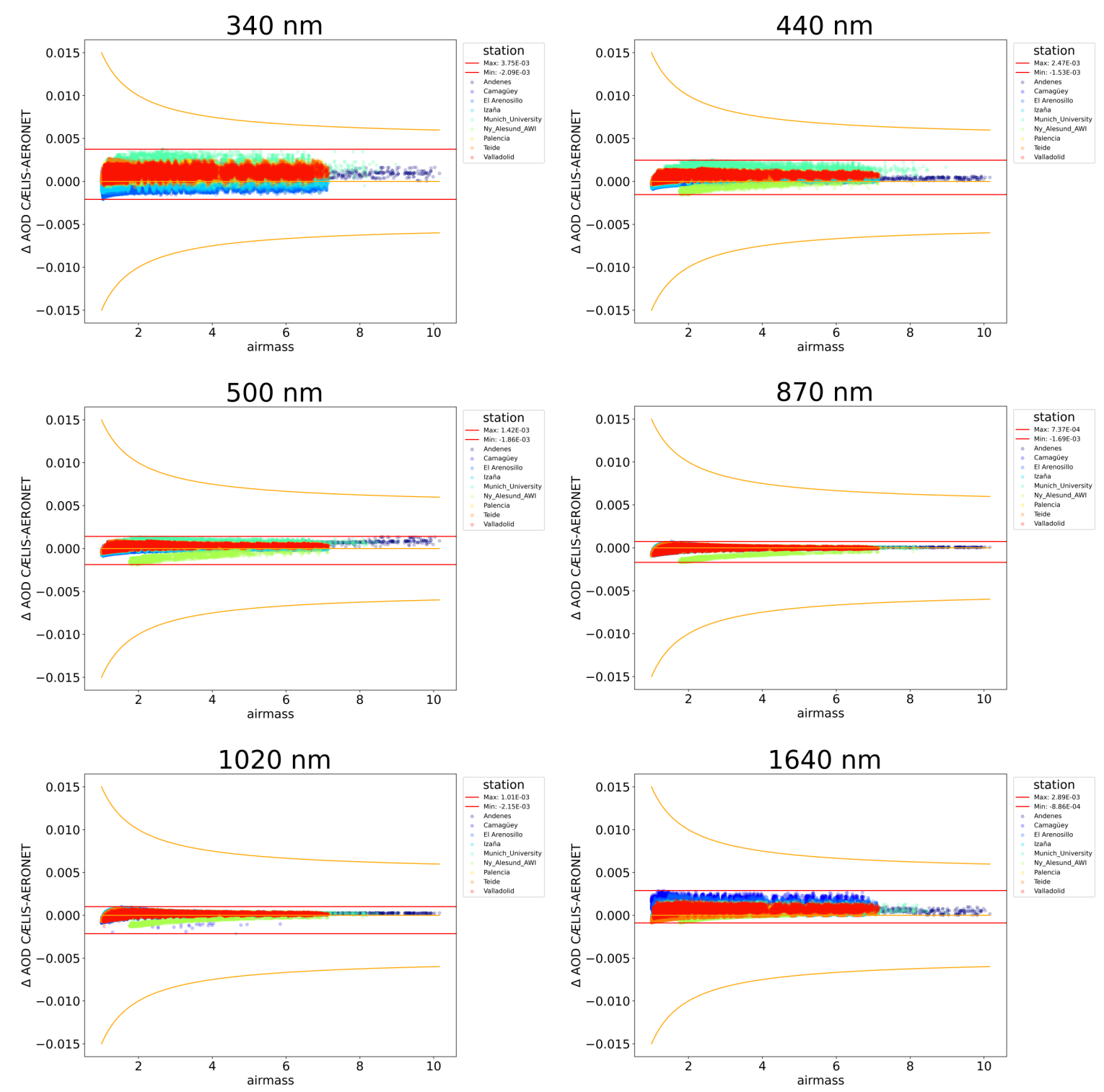

Figure 3.7: Differences in AOD (AERONET-CÆELIS) as a function of air mass for several channels. The red lines indicate the maximum and minimum of the differences. The orange lines indicate the boundaries of the U95 criterion of the WMO (2005) 


\subsection{Artículo 1: Daytime and nighttime aerosol optical depth implementation in CAELIS}

The AOD differences are somewhat site-dependent. Apart from the site coordinates (mainly latitude) that condition the minimum air mass values available for each site, the main relevant difference among sites is the elevation, which affects both the Rayleigh calculations with Bodhaine's formula and the correction by local pressure. The Rayleigh optical depth is larger at shorter wavelengths, and the analysis of this component indicates that it is mainly responsible for the AOD differences for all channels between 340 and 870nm. The differences in Rayleigh optical depth and AOD clearly decrease for increasing wavelength until 870nm. The differences in pressure for the investigated observations are shown in figure $3.3 \mathrm{~b}$. The mean difference is close to zero, and the standard deviation is $1 \mathrm{hPa}$. This is noticeable in short wavelengths: at $340 \mathrm{~nm}$ the Rayleigh optical depth is about 0.70 , and 1-2 $\mathrm{hPa}$ would mean 0.0007 to 0.0015 optical depth. This fact accounts for half of the discrepancy. The rest can be attributed to the gaseous corrections in this channel $\left(\mathrm{O}_{3}\right.$ and $\left.\mathrm{NO}_{2}\right)$.

We also noticed an increase in the AOD discrepancy for longer wavelengths (1020 and especially $1640 \mathrm{~nm}$ ). In this case the Rayleigh correction is minor; therefore, we investigated which elements are causing this. As for $1020 \mathrm{~nm}$, the water vapor absorption correction is the reason for the slightly worse agreement of the $1020 \mathrm{~nm}$ channel. The discrepancy is higher for the 1640nm wavelength. The gaseous corrections are in this case responsible for the AOD differences, i.e., the water vapor absorption and the $\mathrm{CO}_{2}$ and $\mathrm{CH}_{4}$ absorption, which are also affected by the differences in pressure.

Overall, the mean of these differences ranges from $-1.3 \times 10^{-4}$ at $870 \mathrm{~nm}$ to $6.2 \times 10^{-4}$ at $380 \mathrm{~nm}$. The standard deviation of the differences ranges from $2.8 \times 10^{-4}$ at $675 \mathrm{~nm}$ to $8.1 \times 10^{-4}$ at $340 \mathrm{~nm}$. The largest discrepancies are related to the Rayleigh correction (including pressure) and the gaseous absorption corrections. The U95 criterion is fulfilled in any case, and most of the spectral AOD observations agree within 0.0015 on AOD, which is 1 order of magnitude lower that the nominal AOD uncertainty (0.01-0.02) for AERONET field instruments.

\subsection{Nighttime AOD evaluation}

The lunar-derived aerosol optical depth has been developed in recent years following the publication of the ROLO model (Kieffer and Stone, 2005) and the appearance of commercially available lunar photometers (Barreto et al., 2013; Berkoff et al., 2011). It is still a provisional product in AERONET. In this paper we have presented the CÆLIS implementation of the latest improvements in lunar photometry that aims at providing good continuity between solar- and lunar-derived AOD observations. As has been shown in previous works (Barreto et al., 2017, 2019) it is important to assume that nighttime AOD uncertainty is larger that the uncertainty of daytime retrievals, and that it will also depend on Moon phase angle. 


\section{RESULTADOS}

These facts also pose additional difficulty for the cloud screening, apart from the lack of an aureole radiance check to detect thin clouds.

The CÆLLIS nighttime AOD retrievals at several sites and Moon phase angles have been computed, showing continuity with daytime retrievals. We have intentionally selected cases with low AOD in general because absolute errors are easier to detect in low AOD scenes. Moreover, we avoided using the Izaña site for this comparison because lunar measurements at Izaña were used to elaborate the correction proposed to improve AOD (Román et al., 2020).

The results for both the AOD and the AE are shown in Figure 3.8. The upper part (Andenes site) corresponds to a first-quarter case (MPA about $-80^{\circ}$ ). The middle part (Valladolid) is a full Moon case, in which we can see the step from negative to positive MPA during the full Moon. The lowermost part (Granada) is a third-quarter case. The other two parts (for Teide and El Arenosillo) are cases with intermediate (negative and positive) phase angles. Overall, the day-night continuity in AOD is excellent (less than 0.02 in all channels), especially if we bear in mind the AOD natural variability and the nominal uncertainty for daytime AOD of 0.01-0.02, which is larger for shorter wavelengths (Giles et al., 2019; Holben et al. , 1998). The nighttime AOD has no dependence on Moon zenith angle and the AOD wavelength dependence (typical decrease with wavelength) is basically maintained.

The AE has also been included here because this parameter is very sensitive to AOD errors, especially for low AOD (Cachorro et al., 2008). The good continuity and absence of dependence on zenith angle (Sun or Moon) for the AE are reliable indicators of data quality. The continuity of this parameter is also excellent (about 0.1 or less in absolute terms) for all cases except maybe Teide because of the extremely low AOD that amplifies the differences in $\mathrm{AE}$.

Note how instrumental noise is visible in Teide data, wherein AOD is extremely low, whereas for a similar phase angle at El Arenosillo, with higher AOD, such noise is not visible. The plot for El Arenosillo is the only case in which AOD at $500 \mathrm{~nm}$ is above 0.1 . This can be the case for many field sites worldwide, and the agreement among spectral channels and with respect to daytime AOD is a clear indicator that the CÆLIS Moon-derived AOD retrieval and the associated correction (Román et al., 2020) perform as expected.

\subsection{Cloud screening validation}

In this section we have compared the cloud screening performance for daytime AOD data only. The AERONET level 1.5 (cloud-screened) data are used for this analysis. The procedure is very straightforward: we analyze the data with a confusion matrix in order to determine which data assumed to be cloud-free by the AERONET cloud screening algorithm are also 

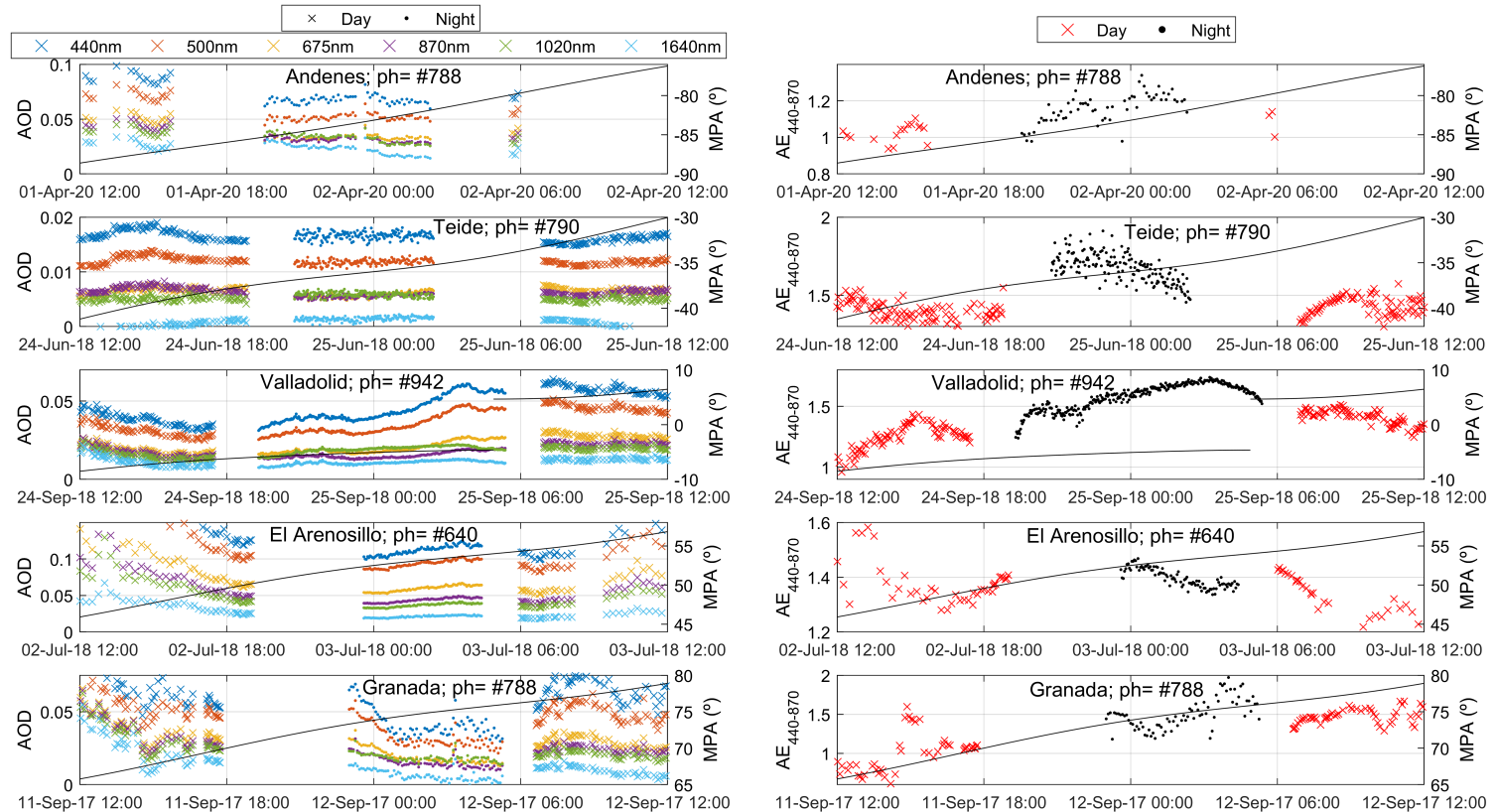

Figure 3.8: (a) Day and nighttime AOD retrievals at different sites and Moon phases. (b) Same for Ångström exponent (440-870nm). The black line indicates the Moon phase angle (MPA, right axis). 


\section{RESULTADOS}

flagged as cloud-free by CÆLIS, and vice versa. The other two possibilities, i.e., that one algorithm indicates cloud but not the other one, represent the discrepancy between the two procedures.

The confusion matrix $C$ is such that $C_{i, j}$ is equal to the number of observations known to be in group $i$ but predicted to be in group $j$ (Pedregosa et al., 2011). Thus, in binary classification, the count of true negatives is $C_{0,0}$, false negatives is $C_{1,0}$, true positives is $C_{1,1}$ and false positives is $C_{0,1}$.

Note that level 1.0 (unscreened data) in AERONET does not include all the measurements attempted by the photometers because many observations with raw signals that are too low or too variable do not qualify for AOD level 1.0 computation (Giles et al., 2019). For those data that passed this first requirement, the AERONET cloud screening will select the cloud-free cases and include them in the level 1.5 database 1 . According to the flagging system of our cloud screening algorithm in CÆLIS, we have compared the cloud-free or restoration flags with the AERONET level 1.5 database for all the investigated sites and time periods (Table 3.1).

The cloud screening comparator links all the photometer observations (full triplet) from CÆELIS with their correspondents in AERONET and stores the output in two different arrays, one for CÆLIS and another one for AERONET. The value of 1 will be stored in each database if the observation is cloud-free and 0 if it is not cloud-free. With those two arrays the confusion matrix has been generated and it can be seen in Figure 3.9, where we indicate the number of observations and the corresponding relative numbers in percent. In the confusion matrix the first row represents all the values that are cloud-free in AERONET, and the second row is for the cloud-contaminated data in AERONET. In the same way, the first column represents the cloud contaminated data in CÆLIS, and the second column includes the cloud-free data in CÆLIS.

More than 250000 observations have been analyzed here. The results are clearly satisfactory, with more than $99.8 \%$ agreement in the classification. The number of points outside the main diagonal of the confusion matrix is marginal. An in-depth study of these few discrepancies, points out that the differences appear in cases in which minor differences in AOD and AE caused a certain threshold to be exceeded or not (triplet variability, daily standard deviation, etc.). Occasionally this also triggered other cloud screening actions, like the potential measurement criteria or 3-sigma threshold. We are therefore very confident that the cloud screening in CÆLIS successfully reproduces the performance of the AERONET version 3 cloud screening.

\footnotetext{
${ }^{1}$ The AERONET data still pass another validation step regarding quality control checks, see Giles et al. (2019) for details.
} 


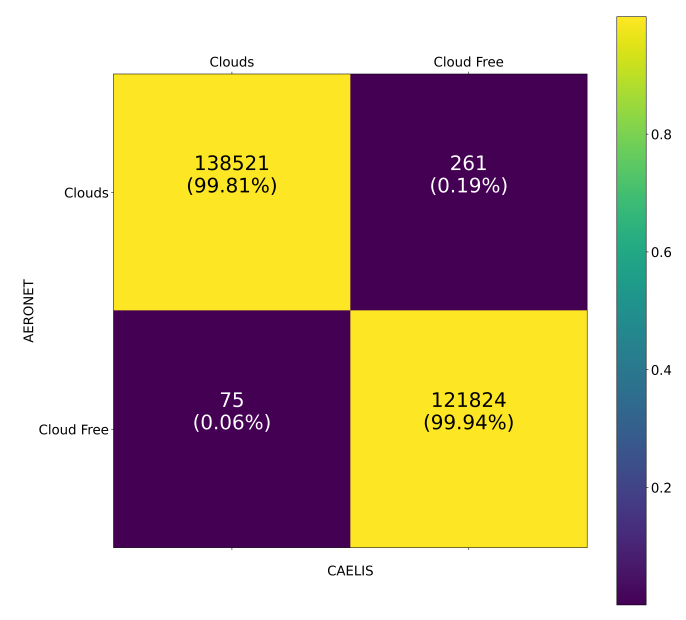

Figure 3.9: Confusion matrix for comparison of the cloud screening performed by AERONET and CÆLIS. Absolute number of cases and relative values (in percent) are given.

\subsubsection{Conclusions}

The CÆLIS software tool was primarily designed to assist in the management of the calibration facility for Cimel photometers at the University of Valladolid, associated with AERONET. It provides access to metadata information to users and intends to facilitate the daily operation of the photometers on-site, with the final aim of improving data quality. CÆLLIS already provides to users processing of sky radiances and a set of flags to monitor the instrument performance in real time. The AOD product now complements this tool. Moreover, the AOD is needed for exploiting remote sensing data with the application of inversion algorithms, like GRASP (Dubovik et al., 2014; Torres et al., 2017). These are the reasons behind the development of an operational aerosol optical depth product and the necessary cloud screening algorithm.

The implemented AOD algorithm comprises a number of steps, following formulas and procedures that are well established in the literature. Comparison with the AERONET version 3 AOD product shows overall agreement better than 0.0015 optical depth ( 1 order of magnitude less than the nominal AOD uncertainty), with the bias and standard deviations being higher for the UV and 1640nm channels. In the UV this is caused by different Rayleigh computation and gaseous correction, and it needs to be investigated further. Similarly, the discrepancy found for the 1640nm channel (slightly higher than that of 1020nm) is caused by differences in the gas absorption corrections. Such differences, even if they are low, can be significant in the case of high-altitude stations or polar sites. The AOD retrieved by CALLIS 


\section{RESULTADOS}

from Moon observations has shown continuity between day and nighttime for different sites and even for low AOD values and Moon phase angles near the Moon quarters.

The cloud screening schemes in CÆLIS and AERONET agree in the identification of cloud-free and cloud-contaminated scenes in more than $99.8 \%$ of the more than 250000 investigated cases. For future investigations, we will need to include a site with predominant biomass burning aerosol since this aerosol type was found to be insufficiently represented in the subset of data used to compare the cloud screening algorithms.

This paper has shown the capability of CÆLIS to provide AOD values and products with a similar accuracy as AERONET. The architecture of CÆLIS is such that is can be applied to other instrument types or networks. The next planned step is to be able to assimilate and process photometers other than the Cimel. In this sense, we will be able to apply a common processing to data originating from different photometer types, each one with its own spectral channels and measurement sequence, for example. Note that AOD retrieval and cloud screening algorithms differ for the different existing networks (AERONET, GAW-PFR, SKYNET). The modular approach has proven to be successful in adding several choices to the data processing or assimilating a variety of ancillary data. This will also help incorporate into the system any future improvements such as new gas absorption coefficients and the extraterrestrial spectral irradiance of the Sun and Moon. The flagging of data allows extracting in a powerful way a subset of data according to the desired criteria.

Some of the steps in the cloud screening procedure are actually quality control flags. However a full quality control of the AOD product is not implemented yet in CÆLIS and will need to be developed. This approach is especially important for a robust operation of the algorithm and possible near-real-time applications.

Data availability. The used data are available from the authors upon request

Author contributions. RG, CT and RR designed and developed the main concepts and ideas behind this work and wrote the paper with inputfrom all authors. They also implemented the cloud screening in CÆLIS. RG, DF, CT and AB implemented the AOD algorithm in CÆLIS.CGF, DM, CVM and JCAS tested the algorithm. AC, VEC and AMdF contributed in the interpretation of results.

Competing interests. The authors declare that they have no conflict of interest.

Acknowledgements. The authors gratefully thank AERONET and PHOTONS teams for the collaboration and support. The authors thank the25Spanish Ministry of Science, Innovation 
and Universities for the support through the ePOLAAR project (RTI2018-097864-B-I00).

Financial support. This research has been supported by the Spanish Ministry of Science and Innovation (grant no. RTI2018-097864-B-I00) and the European Union's Horizon 2020 research and innovation program (grant no. 871115).

Review statement. This paper was edited by Ciro Apollonio ad reviewed by three anonymous referees.

\section{References}

See references section of the $\mathrm{PhD}$ Thesis. 


\subsection{Artículo 2: Correction of a lunar-irradiance model for aerosol optical depth retrieval and comparison with a star photometer}

\subsubsection{Resumen y comentarios}

Como se ha comentado en secciones anteriores, el espesor óptico de aerosoles (AOD) puede ser obtenido a través de la fotometría solar en cualquier ubicación siempre y cuando el Sol esté presente en el cielo. Esto permite tener series de datos continuas, con huecos durante la noche o cuando el sol es tapado por nubes. El problema aparece en aquellas localidades del planeta en las que el Sol no está disponible durante largos periodos de tiempo como en las zonas polares. En ellas habrá un largo vacio de datos durante la noche polar.

El estudio de los aerosoles en estas zonas de forma continuada ha sido muy díficil hasta la adaptación y evolución de los instrumentos fotométricos para medir la irradiancia proveniente de la Luna. Con estos avances se ha resuelto parte del problema de tener datos de forma continuada sin grandes huecos en las series de datos gracias a la fotmetría lunar; sin embargo nuevos retos han aparecido.

Por un lado se encuentra la necesidad de adaptar los procesados de datos para obtener medidas homogéneas y comparables entre los periodos de día y de noche. En el caso de la fotometría lunar existe, además, el reto adicional de conocer con exatitud la irradiancia lunar extraterrestre para cada medida realizada. La irradiancia lunar extraterrestre, a diferencia de la solar, cambia rápidamente ya que la Luna no emite radiación de onda corta si no que refleja la luz solar y, por tanto, la irradiancia lunar extraterrestre dependerá de distintos factores como la distancia Tierra-Luna y Luna-Sol, pero especialmente de la fase lunar. Para poder conocer la irradiancia lunar extrarrestre se usan modelos que estiman sus valores a partir de unas coordenadas geográficas y una fecha.

A lo largo de la sección 3.2.2 se definen el modelo de irradiancia lunar extraterrestre (RIMO) y los procedimientos de calibración (amplificación electrónica - método vicarious) usados en CÆLIS para obtener el AOD durante los periodos de noche. Se ha observado que el modelo RIMO infraestima los valores reales de irradiancia extraterrestre y además está infraestimación depende con la fase lunar. Para corregir esta infraestimación se han calculado unos factores de corrección a partir de medidas fotométricas realizadas bajo condiciones de estabilidad atmosférica y baja turbiedad. Esta corrección se ha implementado en CÆLLS para el cálculo del AOD por la noche.

Los datos de AOD calculados por CÆLIS han sido comparados con los medidos por un fotometro estelar de manera independiente a lo largo de dos años. Esta comparación se 
ha hecho para los canales de 440, 500, 675 y $870 \mathrm{~nm}$. La media de las diferencias entre el AOD de CÆLLS y el del fotómetro estelar se encuentra entre -0.015 y -0.005 con una desviación estandar comprendida entre 0.03 y 0.04 . Estos resultados ponen de manifiesto que el algoritmo implementado en CÆLIS para el calculo del AOD mediante fotometría lunar, el cual incluye la corrección desarrollada, funciona correctamente y proporciona valores nocturnos de espesor óptico de aerosoles de alta calidad, al igual que el implementado en la sección 3.1 .

A continuación, se puede leer en detalle el artículo correspondiente.

\subsubsection{Correction of a lunar-irradiance model for aerosol optical depth retrieval and comparison with a star photometer}

Roberto Román ${ }^{1}$, Ramiro González ${ }^{1}$, Carlos Toledano ${ }^{1}$, África Barreto ${ }^{2,3,1}$, Daniel PérezRamírez $^{4,5}$, Jose A. Benavent-Oltra ${ }^{4,5}$, Francisco J. Olmo ${ }^{4,5}$, Victoria E. Cachorro ${ }^{1}$, Lucas Alados-Arboledas ${ }^{4,5}$, and Ángel M. de Frutos ${ }^{1}$

${ }^{1}$ Group of Atmospheric Optics, University of Valladolid (GOA-UVa), Valladolid, Spain

${ }^{2}$ Izaña Atmospheric Research Center, Meteorological State Agency of Spain (AEMET), Izaña, Spain

${ }^{3}$ Cimel Electronique, Paris, France

${ }^{4}$ Department of Applied Physics, Universidad de Granada, 18071, Granada, Spain

${ }^{5}$ Andalusian Institute for Earth System Research, IISTA-CEAMA, Granada, Spain

Correspondence: Roberto Román (robertor@goa.uva.es)

Abstract The emergence of Moon photometers is allowing measurements of lunar irradi-
ance over the world and increasing the potential to derive aerosol optical depth (AOD) at
night-time, that is very important in polar areas. Actually, new photometers implement the
latest technological advances that permit lunar irradiance measurements together with clas-
sical Sun photometry measurements. However, a proper use of these instruments for AOD
retrieval requires accurate time-dependent knowledge of the extraterrestrial lunar irradiance
over time, due to its fast change throughout the Moon's cycle. This paper uses the RIMO
model (an implementation of the ROLO model) to estimate the AOD at night-time assum-
ing that the calibration of the solar channels can be transferred to the Moon by a vicarious
method. However, the obtained AOD values using a Cimel CE318-T Sun/sky/Moon pho-
tometer for 98 pristine nights with low and stable AOD at the Izaña Observatory (Tenerife, 


\section{RESULTADOS}

Spain) are not in agreement with the expected (low and stable) AOD values, estimated by linear interpolations from daytime values obtained during the previous evening and the following morning. Actually, AOD calculated using RIMO shows negative values and with a marked cycle dependent on the optical airmass. The differences between the AOD obtained using RIMO and the expected values are assumed to be associated with inaccuracies in the RIMO model, and these differences are used to calculate the RIMO correction factor (RCF). The RCF is a proposed correction factor that, multiplied by RIMO value, gives an effective extraterrestrial lunar irradiance that provides AOD closer to the expected values. The RCF varies with the Moon phase angle (MPA) and with wavelength, ranging from 1.01 to 1.14 , which reveals an overall underestimation of RIMO to the lunar irradiance. These obtained RCF values are modeled for each photometer wavelength to a second order polynomial as function of MPA. The AOD derived by this proposed method is compared with the independent AOD measurements obtained by a star photometer at Granada (Spain) for two years. The mean of the Moon-star AOD differences are between -0.015 and -0.005 and the standard deviation between 0.03 and 0.04 (which is reduced to about 0.01 if one month of data affected by instrumental issues is not included in the analysis), for 440, 500, $675 \mathrm{ad} 870 \mathrm{~nm}$; however, for $380 \mathrm{~nm}$, the mean and standard deviation of these differences are higher. The Moon-star AOD differences are also analyzed as a function of MPA, showing no significant dependence.

\subsubsection{Introduction}

Atmospheric aerosols interact with radiation by scattering and absorption mechanisms and with clouds mainly by acting as cloud condensation nuclei, which modify the cloud properties like cloud lifetime or droplet size (Boucher et al. $2013 \mathrm{~b})$. These issues make the aerosol direct and indirect effects to play a crucial role in the Earth's energy budget, being its impact still subject to large uncertainties (IPCC, 2014) due to the large aerosol diversity in size, chemical composition or spatial distribution. These current uncertainties in climate models point out the need to monitor aerosol properties and motivate the study of their interaction mechanisms with the Earth-Atmosphere system (Myhre et al., 2013). In addition, the impact of aerosols is important in several fields such as: air quality and human health (Davidson et al. 2005); marine and land ecosystems (Koren et al., 2006; RaveloPérez et al. , 2016); primary productivity (Jickells et al., 2005), precipitation (Stevens and Feingold, 2009; Twomey, 1977); solar energy production (Neher et al., 2017); or air traffic (Flentje et al. , 2010), among others.

Most of the aerosol studies focused on the aerosol role in the climate change field are based on daytime measurements. However, the knowledge of aerosol properties at night-time 


\subsection{Artículo 2: Correction of a lunar-irradiance model for aerosol optical depth retrieval and comparison with a star photometer}

is also important, especially in polar areas, where a lack of aerosol observations over winter still exists (Graßl and Ritter, 2019; Herber et al., 2002; Mazzola et al., 2012). In addition, a large fraction of aerosols at night-time remains in the residual layer, which may even act as a source for aerosol formation into the boundary layer the next day (Liu et al., 2020; Sun et al., 2013). Moreover, the lack of ultraviolet (UV) radiation at night-time should reduce the events of new particle formation at night since it is reported that solar UV radiation helps to induce some nucleation events (Petäjä et al., 2009). Moreover, the aerosols at night-time can profoundly modify the longwave balance by means of the change in cloud properties, such as cloud lifetime, and the impact on the longwave radiation absorbed by clouds which is back-emitted to the Earth's Surface (Boucher et al., 2013b; Ramanathan et al., 1989).

Two of the most important/used aerosol properties in climate-change studies and modelling are: the aerosol optical depth (AOD), which represents the light extinction in the atmospheric column caused by aerosols; and the so called Ångström Exponent (AE; Angström 1961) which quantifies the AOD spectral variation. These two parameters provide information about the aerosol load and the particle size predominance, respectively. Moreover, AOD values are useful to estimate other aerosol properties in combination with other measurements (e.g., sky radiance and lidar signal) or even without them (Benavent-Oltra et al., 2019; Lopatin et al., 2013; Román et al., 2017b, 2018; Torres et al., 2017). However, ground-based AOD values are usually obtained by solar radiation extinction measurements. In-situ instrumentation is useful to obtain aerosol properties at night-time but they are usually representative only of the aerosol at ground level, with the exception of airborne in-situ measurements (e.g., Remer et al., 1997). Some remote sensing techniques used to derive the aerosol properties at night-time are the Raman lidar systems (Ansmann et al., 1990), which provide AOD but also vertically-resolved extinction profiles; and the star photometers, which derive the AOD from star light extinction measurements (Baibakov et al., 2015, Pérez-Ramírez et al. 2008). The availability of star photometers is very scarce, existing approximately only five star photometers at present in the world operating for aerosol monitoring (Barreto et al. 2019). Recent technical advances allow accurate measurements of direct lunar irradiance (Barreto et al., 2013, Berkoff et al., 2011), therefore the emerging Moon photometry technique appears as a plausible and operative alternative for AOD calculation at night-time. One disadvantage of Moon photometry is that lunar irradiance is only recorded from first to third Moon quarter, which implies a lack of data during half of the Moon cycle.

Some Moon photometers are capable to take measurements of solar and lunar direct irradiances, like the CE318-T Sun/sky/Moon photometer (Cimel Electronique S.A.S.), which is the standard instrument in AERONET (AErosol RObotic NETwork; Holben et al., 1998). This fact allows the well established calibration of the solar channels in the AERONET 


\section{RESULTADOS}

protocols to be transferred to the Moon (Barreto et al., 2016; Li et al., 2016). The main difference between Sun and Moon photometry is that the extraterrestrial lunar irradiance quickly varies even in the course of one night while the extraterrestrial solar irradiance is more stable, with a smooth variation over the year. This remarks the need for knowledge of accurate extraterrestrial lunar irradiance values and their temporal variations. To this end, some models are used, being ROLO (RObotic Lunar Observatory, Kieffer and Stone (2005)) the most widely used in the literature. Here we make use of one implementation of the ROLO named as RIMO (ROLO Implementation for Moon's Observation; Barreto et al., 2019). The irradiance from these models is usually assumed as true for the AOD calculation, however different authors reported some uncertainties and biases in these models (e.g. Barreto et al. 2017; Geogdzhayev and Marshak|2018; Lacherade et al. 2014; Viticchie et al. 2013).

In this framework, the main objective of this work is to evaluate the RIMO accuracy from the differences between the expected AOD in a pristine environment (where AOD is assumed to be low and stable) and the AOD derived by the RIMO with the CE318-T in the same place. The purpose behind this evaluation is to find a correction of the RIMO model that provides an effective lunar extraterrestrial irradiance, which will be assumed as true, useful at least to derive accurate AOD values in the CE318-T bands using the operative SunMoon calibration transfer technique. In addition, this paper aims at studying the performance of the AOD obtained with Moon photometry using the proposed RIMO correction, through a comparison with the AOD from a star photometer.

This paper is structured as follows: Section 3.2.2.2 introduces the sites and instrumentation used in this paper; Section 3.2.2.3 presents the development of the proposed correction on the RIMO lunar irradiance model, while the comparison of the AOD derived using this correction and the one obtained by a star photometer is shown in Section 3.2.2.4. Finally, Section 3.2.2.5 summarizes the main conclusions of this work.

\subsubsection{Sites, Instrumentation and data}

\subsection{Sites}

The RIMO correction proposed in this paper is based on photometer data recorded at the Izaña Meteorological Observatory (IZO; $28.309^{\circ} \mathrm{N} ; 16.499^{\circ} \mathrm{W} ; 2401 \mathrm{~m}$ a.s.1.) in the Canary Islands (Tenerife, Spain), which is managed by the Spanish Meteorological Agency (AEMET). This high-mountain observatory is representative most of the time of the subtropical free troposphere over the North Atlantic, because of its location in the descending branch of the Hadley's cell (Cuevas et al., 2019; Rodríguez et al., 2009). Pristine skies, dry atmospheric conditions and atmospheric stability prevail throughout the year, as a consequence 


\subsection{Artículo 2: Correction of a lunar-irradiance model for aerosol optical depth retrieval and comparison with a star photometer}

of the quasi-permanent temperature inversion layer, normally located below the Izaña's altitude. This situation prevents the vertical transport of anthropogenic pollution from lower levels (Rodríguez et al., 2009).

In terms of AOD, pristine conditions are prevalent in this station, with AOD at $500 \mathrm{~nm}$ below 0.1 and AE above 0.6 (Guirado-Fuentes, 2015). Relatively high AOD conditions due to the Saharan dust transport from North Africa sources to the Atlantic Ocean above the trade wind inversion are prevalent in summer (Basart et al., 2009; Rodríguez et al., 2011), associated typically with the presence of coarse particles (AE below 0.25) and AOD at $500 \mathrm{~nm}$ above 0.1 (Basart et al., 2009, García et al., 2012, Guirado-Fuentes, 2015). These privileged conditions make Izaña Observatory a suitable place for calibration and validation activities (Toledano et al. . 2018). Notwithstanding, Izaña is a calibration site for the GAW-PFR (Global Atmosphere Watch precision-filter radiometer) and AERONET networks (Cuevas et al., 2019), holding a comprehensive measurement programme for atmospheric composition monitoring, being designated by the WMO (World Meteorological Organisation) as a CIMO (Commission for Instruments and Methods of Observation) testbed for aerosols and water vapour remote sensing instruments (WMO, 2014). More details about monitoring programmes at Izaña can be found in Cuevas et al. (2017).

The star photometer measurements of this paper were carried out at the University of Granada (UGR) experimental station, which is the main station of the three belonging to AGORA (Andalusian Global ObseRvatory of the Atmosphere). This station is located at the Andalusian Institute for Earth System Research/IISTA-CEAMA $\left(37.164^{\circ} \mathrm{N} ; 3.605^{\circ} \mathrm{W} ; 680\right.$ $m$ a.s.1.). The UGR station operates many remote sensing instruments in the framework of the ACTRIS (Aerosols, Clouds and Trace Gases, www.actris.eu) infrastructure, being the star photometry data at UGR the only available of this type in ACTRIS. The UGR experimental site is located in city of Granada (Spain), which is a medium-size city (535000 inhabitants in all metropolitan area) at south-eastern Spain. The region presents a continentalMediterranean climate and the city is located in a natural basin surrounded by Sierra Nevada mountains (up to $3500 \mathrm{~m}$ a.s.1.). The city experiences a seasonal evolution of columnar aerosol types, with larger AOD in summer and lower values in winter while the opposite occurs for AE (e.g., Alados-Arboledas et al., 2003; Pérez-Ramírez et al., 2012). The seasonal cycle in columnar aerosol properties is mostly associated with the airmass pattern (Pérez-Ramírez et al. 2016) dominated by the more frequent and intense arrival of Saharan dust during summer (e.g., Antón et al., 2012; Benavent-Oltra et al., 2017; Lyamani et al., 2006; Román et al. 2013; Valenzuela et al., 2012). Anthropogenic aerosol sources in the region are mainly domestic heating and traffic (Lyamani et al., 2010; Titos et al., 2012). Nevertheless, the region 


\section{RESULTADOS}

experiences in winter long periods of air masss stagnations that increase their pollution levels to values compared with other European megacities (e.g., Casquero-Vera et al., 2019).

\subsection{Instrumentation}

The Sun/sky/Moon CE318-T photometer (Cimel Electronique S.A.S.) is used in this work to derive AOD at day and night-time. This photometer is mounted on a two-axis robot and a tracking system allows measurements of direct solar and lunar irradiance, and diffuse sky radiance at different geometries. The photometer head is mainly formed by a collimator, a filter wheel (with narrow interference filters) and two detectors. The usual nominal wavelengths of the photometer filters are 340, 380, 440, 500, 675, 870, 935, 1020 and $1640 \mathrm{~nm}$. The detectors are a Silicon sensor to measure the wavelengths of $1020 \mathrm{~nm}$ and shorter, and an InGaAs sensor to measure the wavelengths equal or longer than $1020 \mathrm{~nm}$; hence $1020 \mathrm{~nm}$ is measured by both detectors. Sky radiance at solar aureole and direct Moon irradiance are measured with the same detectors used to measure direct solar irradiance, but with an electronic amplification factor (gain) of 128 and 4096, respectively; the sky measurements out of the solar aureole are recorded with the same gain than Moon observations.

The CE318-T photometer (and older versions without the capability to observe the Moon) is the standard instrument in AERONET. The photometers used in this paper belong to AERONET, being the \#933 a reference photometer operated at Izaña data, and the photometers \#918 (from 16 ${ }^{\text {th }}$ March 2016 to $25^{\text {th }}$ July 2016), \#751 (from 25 $5^{\text {th }}$ July 2016 to $26^{\text {th }}$ May 2017) and \#788 (from $25^{\text {th }}$ May 2017 to $11^{\text {st }}$ October 2017) the ones operated at UGR station. These photometers were regularly calibrated following the AERONET protocols (Giles et al., 2019; Holben et al., 1998).

The star photometer EXCALIBUR (EXtinction CAmera and LumInance BackgroUnd Register; Astronómica S.L.) operated at UGR station continuously from 2006 to 2011 and during special field campaigns since 2013. A detailed description of the star-photometer EXCALIBUR can be found in Pérez-Ramírez et al. (2008); Pérez-Ramírez et al. (2008). A brief overview is provided here. The star photometer EXCALIBUR largest innovation is the use of a CCD camera as detector attached to a commercial telescope of $30 \mathrm{~cm}$ diameter. A filter wheel permits the allocation of ten interference filters centered at 380, 436, 500, 532, 670,880 and $1020 \mathrm{~nm}$ for aerosol studies, and an additional filter at $940 \mathrm{~nm}$ for precipitable water vapor measurement. In this work the 380, 436, 500, 670 and $880 \mathrm{~nm}$ channels are used. The one at 1020 could not be used due to technical problems. AOD in these spectral bands will be compared to the AOD at 440, 500, 675 and $870 \mathrm{~nm}$ of the CE318-T photometer; the central wavelengths of these bands are close enough (below $10 \mathrm{~nm}$ difference) to allow a direct comparison of measured AOD and avoid interpolated data. If AOD of the CE318-T 


\subsection{Artículo 2: Correction of a lunar-irradiance model for aerosol optical depth retrieval and comparison with a star photometer}

is interpolated to match the star photometer bands, the comparison does not significantly change (in general AOD differences below 0.001). The AOD is computed from direct star irradiance using the one-star method, that is the same approach used for Sun photometry. The one-star method needs only a relative calibration of the instrument, but requires a first calibration for the entire set of stars used (Pérez-Ramírez et al., 2011). Nevertheless, a first calibration of the stars (isolated and stable stars) is enough as the recalibration of the instruments consists only of computing wavelength dependent calibration factors that are the same for all the stars. Star photometer EXCALIBUR is able to provide measurements for all filters in approximately 1-2 minutes, but to minimize the effects of atmospheric turbulence data were averaged every $30 \mathrm{~min}$ (Pérez-Ramírez et al., 2011). A procedure based on moving averages an outlier removal is used for cloud-screening and data quality check (Pérez-Ramírez et al. 2012). In addition, a visual inspection of data has been carried out to remove spurious data. Final uncertainties in AOD are 0.02 for wavelengths below 800 $\mathrm{nm}$ and 0.01 for wavelengths above $800 \mathrm{~nm}$ (Pérez-Ramírez et al., 2011). Other authors reported a higher uncertainty in AOD from star photometry, about 0.02-0.03 (Baibakov et al. 2015; Barreto et al., 2019). The analysed period in this work is for coincident measurements of star and Moon photometer, and can be divided in two periods, in the framework of the SLOPE (Sierra Nevada Lidar AerOsol Profiling Experiment) I and II field campaigns (Bedoya-Velásquez et al., 2018; Casquero-Vera et al., 2020; de Arruda Moreira et al., 2018): from May 25 $5^{\text {th }}, 2016$ to September 17 ${ }^{\text {th }}, 2016$; and from July $1^{\text {st }}, 2017$ to October $17^{\text {th }}$, 2017. Just before the second measurement period, EXCALIBUR was measuring at Izaña in the first multi-instrument nocturnal intercomparison campaign (Barreto et al., 2019).

\subsection{Data management}

The University of Valladolid (UVa; Spain) is in charge of one AERONET calibration center since 2006 and, in this framework, the UVa staff developed the CÆLIS software tool (Fuertes et al. 2018) with the aim of managing the data generated by AERONET photometers and for calibration and quality control purposes. This tool contains relevant information about the different photometers, like the spectral response of the filters or the signal temperature correction coefficients, and also includes climatology tables of different atmospheric variables (like pressure or the abundance of several absorption gases) useful to perform the atmospheric correction in the AOD calculation. An AOD calculation algorithm has recently been implemented in CÆLIS (González et al., 2020b). Therefore, the day and night-time AOD data from the CE318-T measurements used in this work have been obtained from CÆLIS. 


\section{RESULTADOS}

\subsubsection{AOD from Moon observations}

A main advantage of Sun photometry is that the measured irradiance is directly emitted by the Sun and then, the solar irradiance reaching the top of atmosphere (extraterrestrial irradiance) does not significantly change, at least along one day. The Earth-Sun distance is the main factor modulating this irradiance, causing variations about $\pm 3 \%$ along the year. Following the Beer-Bouguer-Lambert law, the extraterrestrial signal of the instrument (rather than irradiance in physical units) is needed for AOD calculation. This can be obtained by the Langley plot method (Shaw, 1976, 1983), in which direct Sun irradiance is observed at different solar elevations in order to extrapolate the top-of-the-atmosphere signal of the instrument. Side by side comparison with a reference instrument is the common practice in AERONET for calibration transfer in field instruments (Giles et al., 2019; González et al., 2020b; Holben et al., 1998; Toledano et al., 2018). However, the Moon is not a self-illuminating body. It reflects solar radiation with exceptional stability (Kieffer and Stone, 2005). Due to the changing positioning of Sun, Moon and Earth, lunar irradiance at the top of the Earth's atmosphere significantly changes with the Moon Phase Angle (MPA), even along one single night. This fact points out the need of accurate knowledge of the extraterrestrial lunar irradiance for Moon photometry purposes. In this framework, AOD from lunar irradiance observations can be calculated following the Beer-Bouguer-Lambert law, as follows (Barreto et al., 2013):

$$
\tau_{a}(\lambda)=\frac{\ln \left[\kappa^{M}(\lambda)\right]-\ln \left[V^{M}(\lambda) / E_{0}^{M}(\lambda)\right]-m_{g} \cdot \tau_{g}(\lambda)-m_{R} \cdot \tau_{R}(\lambda)}{m_{a}}
$$

where $\tau_{a}$ and $\kappa^{M}$ are the AOD and the Moon calibration coefficient, respectively, for a nominal $\lambda$-wavelength; $E_{0}^{M}$ and $V^{M}$ are the extraterrestrial lunar ${ }^{1}$ irradiance and the photometer lunar signal at the same nominal $\lambda$-wavelength, respectively; while $m_{a}, m_{R}$ and $m_{g}$ are the optical airmass for aerosols, Rayleigh scattering and gaseous absorption, respectively, using the Moon Zenith Angle (MZA) instead of Solar Zenith Angle (SZA). Finally, $\tau_{R}$ and $\tau_{g}$ represent the optical depth of Rayleigh scattering and gaseous absorption, respectively. More details about these calculation in CÆLIS can be found in González et al. (2020b).

\subsection{Extraterrestrial Lunar Irradiance}

As already mentioned, the knowledge of the extraterrestrial lunar irradiance is necessary in Moon photometry. To this end, the RIMO model has been implemented in CÆLIS. RIMO (http://testbed.aemet.es/rimoapp), which is described in detail in Barreto et al.

\footnotetext{
${ }^{1}$ hereafter the superscripts $M$ and $S$ will make reference to Moon or Sun respectively.
} 


\subsection{Artículo 2: Correction of a lunar-irradiance model for aerosol optical depth retrieval and comparison with a star photometer}

(2019), is an implemetation of the ROLO model (Kieffer and Stone, 2005), which is mainly based on empirical relationships between the lunar irradiance measured at 32 channels by two CCD devices, both mounted in a telescope, and the different geometrical factors of the Moon-observer positions. RIMO firstly calculates the reflectance of the Moon's disk following the next equation (Eq. (12) in Barreto et al., 2019):

$$
\begin{array}{r}
\ln [A(k)]=\sum_{i=0}^{3} a_{i}(k) g_{r}^{i}+\sum_{j=1}^{3} b_{i}(k) \Phi^{2 j-1}+c_{1} \phi+c_{2} \theta+c_{3} \Phi \phi+ \\
c_{4} \Phi \theta+d_{1}(k) \exp \left(-\frac{g_{d}}{p_{1}}\right)+d_{2}(k) \exp \left(-\frac{g_{d}}{p_{2}}\right)+d_{3}(k) \cos \left(\frac{g_{d}-p_{3}}{p_{4}}\right)
\end{array}
$$

where $A$ is the Moon's reflectance at one of the $32 k$-wavelengths of the ROLO model; the $a, b, c, d$ and $p$ values are the coefficients shown in Kieffer and Stone (2005); $g_{r}$ and $g_{d}$ are the absolute value of MPA in radians and in degrees, respectively; $\Phi$ is the selenographic longitude of Sun (in radians); $\theta$ and $\phi$ are the selenographic latitude and longitude of the observer, respectively, both in degrees (Barreto et al., 2019).

The Moon's reflectance $A$ is calculated by RIMO using equation (3.11) at the 32 ROLO wavelengths and, then, each one is multiplied by a correction factor which was previously calculated by the comparison between a composite spectrum ( $95 \%$ soil) of Moon's reflectance based on Apollo 16 samples (soil and breccia) and the reflectance obtained with the equation (3.11), assuming zero libration and $g=\Phi=7^{\circ}$ (see Barreto et al. 2019 for more details). The Moon's reflectance at any different wavelength is obtained by linear interpolation of the $A$ calculated values. Finally, in order to obtain the lunar irradiance from the Moon's reflectance, some geometric factors such as the distances between the Moon, the Sun and the observer must be taken into account, as follows:

$$
E_{0}^{M}(\lambda)=\frac{A(\lambda) \cdot \Omega_{M} \cdot E_{0}^{S}(\lambda)}{\pi}\left(\frac{1 A U}{D_{S-M}}\right)^{2}\left(\frac{384400 k m}{D_{O-M}}\right)^{2}
$$

where $E_{0}^{M}$ and $A$ are the extraterrestrial lunar irradiance and the Moon's reflectance, respectively, both at the $\lambda$-wavelength; $E_{0}^{S}$ is the extraterrestrial solar irradiance at the $\lambda$ wavelength being obtained from Wehrli (1985) smoothed by a Gaussian filter of $2 \mathrm{~nm}$ width; $\Omega_{M}$ is the solid angle of the Moon $(6.4177 \mathrm{E}-5 \mathrm{sr})$; and $D_{S-M}$ and $D_{O-M}$ are the distances between the Sun and the Moon (in AU) and between the observer and the Moon (in km), respectively. These distances, the MZA and all the geometrical angles involved in equation (3.11) are obtained from the SPICE Toolkit (http: / / naif .jpl . nasa.gov/naif /toolkit.html) (Acton et al., 2018; Acton, 1996) developed by the NASA's Navigation 


\section{RESULTADOS}

and Ancillary Information Facility (NAIF). SPICE is run using the planetary and lunar ephemeris DE421 (Folkner et al., 2008) in addition to planetary constants kernel for the Moon (moon_pa_de421_1900 - 2050.bpc), and lunar frames kernel (moon_080317.tp) (Seidelmann et al., 2007; Speyerer et al., 2016); the SPICE kernels pck00010.tpc and naif0011.tls are also used for other planetary and time parameters. The NAIF pinpoint tool is used to calculate the position of the observer in each station regarding the Mean Earth body-fixed reference system $\left(M O O N_{-} M E\right)$.

\subsection{Gain Calibration Method}

Once the extraterrestrial lunar irradiance is obtained from geographical and time inputs, the AOD can be calculated at night-time using equation (3.10) if the calibration coefficient $\kappa$ is known. Different methods are proposed in the literature for calibration purposes (calculation of $\kappa$ ) since the accuracy of the Langley-plot method could be affected by the fast variations of the Moon illumination. One way is the so-called Lunar Langley calibration method (Barreto et al., 2013, 2016), which is similar to a classic Langley-plot calibration but where the photometer signal is divided by the extraterrestrial lunar irradiance, as follows:

$$
\ln \left[\frac{V^{M}(\lambda)}{E_{0}^{M}(\lambda)}\right]=\ln \left[\kappa^{M}(\lambda)\right]-m_{a} \cdot\left(\tau_{a}(\lambda)+m_{R} \frac{\tau_{R}(\lambda)}{m_{a}}+m_{g} \frac{\tau_{g}(\lambda)}{m_{a}}\right)
$$

Under stable atmospheric conditions, $\kappa^{M}$ can be obtained from the y-intercept of a least square fit between $\ln \left(V^{M} / E_{0}^{M}\right)$ and the aerosol optical airmass. However, the possible errors and uncertainties in $E_{0}^{M}$ are propagated to the value of $\kappa$ obtained by this method, although these uncertainties are partially masked in the AOD retrieval (equation (3.10) because the $E_{0}^{M}$ values are also used in the calculation. Recently, Barreto et al. (2017) found a dependence on MPA and MZA of the AOD calculated by this Lunar Langley method.

Another way to calculate $\kappa^{M}$ without the use of $E_{0}^{M}$ is by the so called Gain calibration method (Barreto et al. 2016). This method, based on a vicarious calibration, consists of transferring the calibration of the solar channels to the respective Moon ones. Both CE318$\mathrm{T}$ detectors are the same for solar and lunar irradiance measurements. In order to reach a higher signal range, the Moon signal is amplified, being multiplied by a gain factor, $G$. In fact, this factor is formed by 2 amplification steps, being the first one the Sun to solar aureole gain $(\approx 128)$ and the second one the solar aureole to Moon gain $(\approx 32)$. The nominal value of $G$ is therefore equal to $4096\left(2^{12}\right)$. The values of $G$ were measured with an integrating sphere in the laboratory by Barreto et al. (2016) and Li et al. (2016). These authors found experimental values for $G$ differing less than $0.3 \%$ from the nominal value of 4096 ; hence, $G$ 


\subsection{Artículo 2: Correction of a lunar-irradiance model for aerosol optical depth retrieval and comparison with a star photometer}

is assumed in CÆLIS as wavelength independent and with a constant value of 4096. Taking into account that the only difference between Sun and Moon measurements is this Gain factor, the Sun calibration can be transferred to Moon as follows:

$$
\kappa^{M}(\lambda)=\frac{V_{0}^{S}(\lambda)}{E_{0}^{S}(\lambda)} \cdot G
$$

where $V_{0}^{S}$ is the Sun calibration coefficient and $E_{0}^{S}$ the extraterrestrial solar irradiance (Wehrli, 1985), both at the $\lambda$-wavelength. The Gain calibration is simpler than Lunar Langley method because it is not dependent on the RIMO (or other lunar irradiance model) and it only requires the daytime calibration, which provides more operational character to this method.

\subsection{RIMO Correction Factor}

In order to evaluate the AOD obtained by the Gain calibration, the method of Barreto et al. (2017) has been followed, who assumed as a reference AOD, $A O D_{r e f}$, the linear temporal interpolated values using the last daytime AOD value of the previous afternoon and the first AOD of the following morning, which make sense if stable and pristine conditions were found during the night. Hence, the AOD obtained by the Gain calibration, equation (3.14) and (3.12) in equation (3.10), has been calculated for several nights that satisfied pristine and stable conditions to be compared against $A O D_{\text {ref }}$. Data from the \#933 CE318-T photometer located at IZO have been selected for this purpose, since this high-elevation remote site usually presents unique atmospheric conditions with very low and stable AOD values. The morning and afternoon solar Langley-plots from this photometer have been calculated, and stable conditions have been assumed when these Langley-plots present more than 25 data, the AOD at $500 \mathrm{~nm}$ below 0.025 and the standard deviation below 0.006 (see Toledano et al., 2018). The nights for which both the previous afternoon and the next morning solar Langley-plots fulfill the mentioned criteria, have been selected as the 'stable and pristine' nights. The AOD has been calculated for these selected nights but discarding optical airmasses larger than 6 and data under MPA absolute values above $90^{\circ}$. Moreover, a total of 37 cloud contaminated nights have been manually discarded by visual inspection (nights without a smooth AOD time series) in order to warranty the AOD quality. As result, around 13500 AOD data points per wavelength, corresponding to 98 pristine and stable nights from June 2014 to March 2018 at IZO, have been selected.

The differences between the AOD obtained by the Gain calibration and the reference values $\left(\triangle A O D_{G-r}\right)$ have been calculated following the next equation:

$$
\Delta \tau_{G-r}(\lambda)=\tau_{\text {Gain }}(\lambda)-\tau_{\text {ref }}(\lambda)
$$




\section{RESULTADOS}

where $\Delta \tau_{G-r}, \tau_{\text {Gain }}$ and $\tau_{\text {ref }}$ are $\Delta A O D_{G-r}$, the AOD from the Gain calibration and the interpolated AOD used as reference $\left(A O D_{r e f}\right)$, respectively, for the $\lambda$-wavelength. Figure 3.10a shows the obtained $\triangle A O D_{G-r}$ values as a function of the MPA at IZO for the 98 chosen stable nights and for all photometer channels. These differences show negative values, which is because the calculated AOD with Gain method and RIMO model is mostly below zero. A fictitious nocturnal cycle, symmetrical with the optical airmass, appears in these differences, and hence in the calculated AOD with Gain method and RIMO; this kind of fictitious cycle are usually associated in Sun photometry to a deficient calibration (Cachorro et al., 2004, 2008; Guirado et al., 2014). However, in Moon photometry this cycle, as equation 3.10 evidences, could be also caused by inaccuracies in the used $E_{0}^{M}$ values. Barreto et al. (2017) found a similar behaviour in these differences but being close to zero for $\mathrm{MPA} \approx 0$ and increasing with the absolute phase, which could be explained because they used Lunar Langley calibration near to the full Moon and it masked the possible bias on RIMO at least close to MPA $\approx 0$. Assuming the Gain calibration and $A O D_{\text {ref }}$ are accurate, and all the differences between AOD and the reference are caused by RIMO inaccuracies, the $\triangle A O D_{G-r}$ can be expressed as 1 ;

$$
\Delta \tau_{G-r}(\lambda)=\frac{1}{m} \cdot \ln \left[\frac{E_{0-r e f}^{M}(\lambda)}{E_{0-R I M O}^{M}(\lambda)}\right]
$$

where $E_{0-R I M O}^{M}$ is the extraterrestrial lunar irradiance from RIMO (the one used in CÆlis) and $E_{0-r e f}^{M}$ is the extraterrestrial lunar irradiance that provides the $A O D_{\text {ref }}$ if the Gain calibration is applied, both for the $\lambda$-wavelength. A correction factor that transforms RIMO irradiance into the reference irradiance, named RIMO Correction Factor (RCF), is defined as the ratio between the extraterrestrial lunar irradiance assumed as reference and the obtained by RIMO. RCF can be derived for each $\lambda$-wavelength from equation (3.16) as:

$$
R C F(\lambda)=\frac{E_{0-r e f}^{M}(\lambda)}{E_{0-R I M O}^{M}(\lambda)}=\exp \left[m \cdot \Delta \tau_{G-r}(\lambda)\right]
$$

The RCF values have been calculated by equation (3.17) using the data of Figure 3.10a, and they are shown in Figure $3.10 \mathrm{~b}$. The UV channels present high dispersion, while the longer wavelengths point out a decay in RCF close to the full Moon. The other channels show less dependence on MPA and, excluding the UV channels, the extraterrestrial lunar irradiance from RIMO underestimates the assumed as reference between $1 \%$ and $14 \%$ (between $3 \%$ and $12 \%$ for MPA absolute values between $5^{\circ}$ and $70^{\circ}$ ). This last result is in agreement with the differences reported by Lacherade et al. (2014), who found that ROLO

\footnotetext{
${ }^{1}$ In order to simplify hereafter $\tau_{a}$ and $m_{a}$ are expressed as $\tau$ and $m$, respectively, without $a$ subscript.
} 


\subsection{Artículo 2: Correction of a lunar-irradiance model for aerosol optical depth retrieval and comparison with a star photometer}

underestimates around 6-12\% (in the same MPA range than in this paper) for wavelengths between 505 and $844 \mathrm{~nm}$, using as reference an imagery absolute calibrated system on board two PLEIADES satellites. Geogdzhayev and Marshak (2018) observed that ROLO underestimates, within 10\%, the irradiance at six wavelengths between 443 and $780 \mathrm{~nm}$ using EPIC (Earth Polychromatic Imaging Camera) images, calibrated using MODIS (Moderate Resolution Imaging Spectroradiometer) data. Viticchie et al. (2013) found also a positive bias around 15\% between Moon observations from SEVIRI (Spinning Enhanced Visible and Infrared Imager) on-board MSG2 satellite (Meteosat Second Generation) and the ROLO model at $1600 \mathrm{~nm}$, and a behaviour close to the full Moon similar to the observed in Figure $3.10 \mathrm{~b}$ for the longer wavelengths. These independent results point out that ROLO, and hence its implementation RIMO, underestimates the extraterrestrial lunar irradiance, which is in concordance with the obtained results and reinforces the hypothesis that the Gain calibration method is appropriate.

Viticchie et al. (2013) and Lacherade et al. (2014) observed a dependence of the differences between ROLO and satellite observations on MPA, and these dependencies on MPA are also observed in RIMO in Figure 3.10p. Uchiyama et al. (2019) used the Lunar Langley technique to observe an underestimation of the ROLO reflectance (given by equation (3.11)) with a MPA dependence fitted to a quadratic equation of the absolute value of the Moon phase angle $\left(C=A_{c} g^{2}+B_{c} ; g=\right.$ Moon phase angle) compared with the reflectance obtained with photometer measurements; however, these authors did not consider the use of the solar spectrum of Wehrli (1985), which was used by Kieffer and Stone (2005) to derive the Moon reflectance of ROLO, neither asymmetries on the phase angle dependence of ROLO reflectance correction. Considering the results reported in the literature, RCF values of Figure $3.10 \mathrm{p}$ have been fitted by a least square method to a 2 nd order polynomial as a function of MPA:

$$
R C F(\lambda)=a(\lambda)+b(\lambda) \cdot g+c(\lambda) \cdot g^{2}
$$

where $g$ is the MPA, and $a, b$ and $c$ the fitting coefficients at $\lambda$-wavelength. The obtained coefficients are shown in Table 3.2 for the different wavelengths. The uncertainty on the $a$ coefficient is $4 \mathrm{e}-3$ for $340 \mathrm{~nm}, 1.7 \mathrm{e}-3$ for $380 \mathrm{~nm}$ and $6 \mathrm{e}-4$ for the other channels; these uncertainty on $b$ is $1.2 \mathrm{e}-2 \mathrm{rad}^{-1}$ for $340 \mathrm{~nm}, 4 \mathrm{e}-3 \mathrm{rad}^{-1}$ for $380 \mathrm{~nm}, 7 \mathrm{e}-4 \mathrm{rad}^{-1}$ for 440,675 and 1020 (InGaAs) nm channels, and $6 \mathrm{e}-4 \mathrm{rad}^{-1}$ for the rest; in the case $c$ the uncertainty is 2e- $2 \mathrm{rad}^{-2}$ for $340 \mathrm{~nm}, 5 \mathrm{e}-3 \mathrm{rad}^{-2}$ for $380 \mathrm{~nm}, 8 \mathrm{e}-4 \mathrm{rad}^{-2}$ for $440 \mathrm{~nm}$ and 1020 (InGaAs), and $7 \mathrm{e}-4 \mathrm{rad}^{-2}$ for the other channels. This uncertainty has been calculated by the propagation of the uncertainty on $\tau_{\text {Gain }}$ (assumed as 0.02 as conservative value (Barreto et al., 2016) ) and $\tau_{\text {ref }}$ (assumed as 0.02 for the UV channels and 0.01 for the others) of Eq. 3.15 


\section{RESULTADOS}
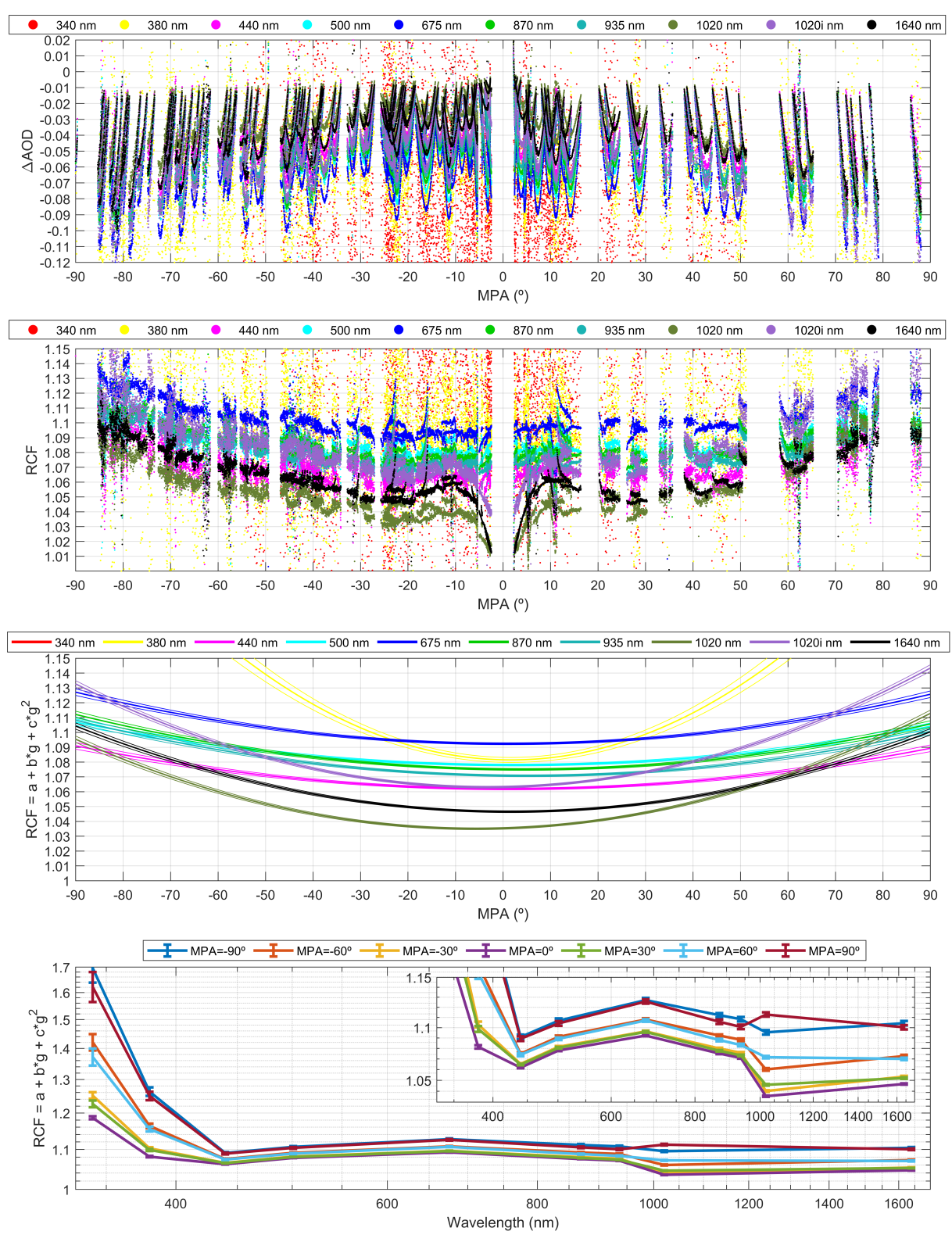

Figure 3.10: a) Differences between AOD from Gain calibration and the reference values at night as function of Moon Phase Angle (MPA) for different wavelengths; b) RIMO Correction Factor (RCF) against MPA for different wavelengths; c) Fitted RCF and \pm its propagated uncertainty vs. MPA for different wavelengths (340 $\mathrm{nm}$ values are not shown because they are out of the axis limits); and d) Fitted RCF and \pm its propagated uncertainty (error bars) against the nominal wavelength of each CE318-T channel, for different MPA values. 


\subsection{Artículo 2: Correction of a lunar-irradiance model for aerosol optical depth retrieval and comparison with a star photometer}

the RCF values produced by the retrieved coefficients are also shown in Figure 3.10k, indicating RCF values between 1.03-1.14 for all MPA range except for the UV channel, for which the fit indicates much larger dependence on MPA. The coefficients for $340 \mathrm{~nm}$ channel have been calculated only using data with MPA absolute values lower or equal to $55^{\circ}$ since the AOD at $340 \mathrm{~nm}$ is too noisy due to the low lunar signal, especially far from the full Moon. The discrepancies in the RCF value for $1020 \mathrm{~nm}$ between Silicon and InGaAs (1020i) channels (see Figure $3.10 \mathrm{p}$ ) are also marked in the fitting coefficients which point out a RCF overestimation of InGaAs over Silicon around 0.03. The median (MD) and standard deviation $(S D)$ of the RCF fitting residuals $\left(R C F_{\text {resid }}\right)$ are also in Table 3.2, showing the worst fit for UV channels followed by $440 \mathrm{~nm}$ and the InGaAs channels; the InGaAs channels present a median and standard deviation in the RCF residuals around -0.001 and 0.013 , respectively, which could explain part of the mentioned discrepancies between the RCF values at 1020 $\mathrm{nm}$ in both Silicon and InGaAs channels. On the other hand, the lowest deviation (around 0.01 ) is reached for the 675,870 and $935 \mathrm{~nm}$. The uncertainty on RCF caused by the uncertainty on the coefficients is also shown in Figure 3.10k. This uncertainty increases with MPA and is in general low except for the UV channels. Figure $3.10 \mathrm{~d}$ shows the RCF values as a function of the nominal wavelengths of the photometer channels and for a set of MPA values. The uncertainty of the RCF increases with MPA as observed in Figure 3.10k. About the variation of RCF with wavelength, it is similar for the different MPA values, being always larger for negative MPA values than for positive ones, except for 1020 channel. The RCF strongly decreases from 340 to $440 \mathrm{~nm}$, while from 440 to $935 \mathrm{~nm}$ the variation is smoother, increasing from 440 to $675 \mathrm{~nm}$ and decreasing from 675 to $935 \mathrm{~nm}$. This result could lead us to think that RCF can be calculated for other wavelengths by interpolation. However, the spectral variation of RCF is unknown and smooth or linear behaviour cannot be assumed. RIMO lunar reflectance values are calculated at 32 spectral bands which are interpolated to the other wavelengths, the accuracy of RIMO could drastically vary between two different RIMO bands. Therefore, the interpolation of RCF to other bands is not recommended or at least must be taken with care. The spectral uncertainty and accuracy of RCF is not known out of the CE318-T spectral bands.

Unifying equation (3.10), 3.12), (3.14) and (3.18) with the coefficients of Table 3.2 the AOD can be calculated using the Gain calibration method as:

$$
\begin{array}{r}
\tau(\lambda)=\frac{1}{m} \cdot \ln \left[\frac{V_{0}^{S}(\lambda)}{V^{M}(\lambda)} \cdot \frac{R C F(\lambda) \cdot A(\lambda)}{\left(D_{O-M} \cdot D_{S-M}\right)^{2}} \cdot \frac{384400^{2} \cdot \Omega_{M} \cdot G}{\pi}\right]- \\
\frac{1}{m} \cdot\left[m_{R} \cdot \tau_{R}(\lambda)+m_{g} \cdot \tau_{g}(\lambda)\right]
\end{array}
$$




\section{RESULTADOS}

Table 3.2: Fitting coefficients of the RIMO Correction Factor (equation 3.17 ), the number of used data $(N)$, and median $(M d)$ and standard deviation $(S D)$ of the residuals in RIMO Correction Factor (RCF) and aerosol optical depth (AOD) for different photometer wavelengths. The fitting values at $340 \mathrm{~nm}$ has been obtained without MPA absolute values above $55^{\circ}$.

\begin{tabular}{ccccccccc}
\hline \hline$\lambda(n m)$ & $\mathrm{N}$ & $\mathrm{a}$ & $\mathrm{b}\left(\right.$ rad $\left.^{-1}\right)$ & $\mathrm{c}\left(\right.$ rad $\left.^{-2}\right)$ & $M d\left(R C F_{\text {resid }}\right)$ & $S D\left(R C F_{\text {resid }}\right)$ & $M d\left(A O D_{\text {resid }}\right)$ & $S D\left(A O D_{\text {resid }}\right)$ \\
\hline \hline 340 & 8895 & 1.186 & $-2.35 \mathrm{e}-02$ & $1.92 \mathrm{e}-01$ & $6.15 \mathrm{e}-02$ & $4.89 \mathrm{e}-01$ & $3.42 \mathrm{e}-02$ & $1.21 \mathrm{e}-01$ \\
\hline 380 & 13447 & 1.082 & $-4.17 \mathrm{e}-03$ & $7.10 \mathrm{e}-02$ & $4.41 \mathrm{e}-03$ & $1.70 \mathrm{e}-01$ & $2.46 \mathrm{e}-03$ & $5.37 \mathrm{e}-02$ \\
\hline 440 & 13496 & 1.062 & $-5.35 \mathrm{e}-04$ & $1.14 \mathrm{e}-02$ & $-4.71 \mathrm{e}-04$ & $1.59 \mathrm{e}-02$ & $-2.41 \mathrm{e}-04$ & $8.23 \mathrm{e}-03$ \\
\hline 500 & 13496 & 1.078 & $-8.93 \mathrm{e}-04$ & $1.11 \mathrm{e}-02$ & $-2.71 \mathrm{e}-04$ & $1.28 \mathrm{e}-02$ & $-1.38 \mathrm{e}-04$ & $6.88 \mathrm{e}-03$ \\
\hline 675 & 13496 & 1.092 & $-4.50 \mathrm{e}-04$ & $1.38 \mathrm{e}-02$ & $-1.77 \mathrm{e}-04$ & $1.13 \mathrm{e}-02$ & $-8.77 \mathrm{e}-05$ & $6.06 \mathrm{e}-03$ \\
\hline 870 & 13496 & 1.075 & $-2.05 \mathrm{e}-03$ & $1.37 \mathrm{e}-02$ & $-3.00 \mathrm{e}-04$ & $1.12 \mathrm{e}-02$ & $-1.53 \mathrm{e}-04$ & $6.17 \mathrm{e}-03$ \\
\hline 935 & 13494 & 1.071 & $-2.41 \mathrm{e}-03$ & $1.36 \mathrm{e}-02$ & $-2.29 \mathrm{e}-04$ & $1.12 \mathrm{e}-02$ & $-1.21 \mathrm{e}-04$ & $6.24 \mathrm{e}-03$ \\
\hline 1020 & 13495 & 1.035 & $5.55 \mathrm{e}-03$ & $2.79 \mathrm{e}-02$ & $-2.36 \mathrm{e}-04$ & $1.32 \mathrm{e}-02$ & $-1.18 \mathrm{e}-04$ & $7.78 \mathrm{e}-03$ \\
\hline $1020 \mathrm{i}$ & 13495 & 1.063 & $3.40 \mathrm{e}-03$ & $3.04 \mathrm{e}-02$ & $-7.35 \mathrm{e}-04$ & $1.35 \mathrm{e}-02$ & $-3.63 \mathrm{e}-04$ & $8.09 \mathrm{e}-03$ \\
\hline 1640 & 13495 & 1.047 & $-1.25 \mathrm{e}-03$ & $2.26 \mathrm{e}-02$ & $-4.38 \mathrm{e}-04$ & $1.27 \mathrm{e}-02$ & $-2.25 \mathrm{e}-04$ & $8.09 \mathrm{e}-03$ \\
\hline \hline
\end{tabular}

which is the final way used by CÆLIS to derive AOD at night-time, adding the RCF values and using the Gain method to transfer Sun to Moon calibration. It is important to remark that this AOD retrieval is based on the assumption of linear behaviour of the instrument with respect to the measured irradiance, but this assumption is reasonable as it was observed by Taylor et al. (2018), who found that nonlinearity can be considered negligible for the CE318-T instrument at Moon irradiance levels.

Finally, in order to see how the residuals in the RCF fitting are propagated to the AOD, the median and standard deviation of the residuals between the AOD from equation (3.19) and the $A O D_{\text {ref }}$ in the 98 chosen stable nights (used in the RCF fitting) are calculated and shown in Table 3.2. The highest AOD deviation appears for the UV channels, especially for $340 \mathrm{~nm}$ (even taking into account that MPA absolute values above $55^{\circ}$ has been discarded), being about 0.12 . The AOD deviations are below 0.01 for all channels above $400 \mathrm{~nm}$, being the highest for $440 \mathrm{~nm}$ and the InGaAs channels (1020i and 1640nm). As in RCF residuals, the lowest deviations are found in 675, 870 and $935 \mathrm{~nm}$ channels. These results point out that the $340 \mathrm{~nm}$ channel (at least for MPA absolute values above $55^{\circ}$ ), and possibly 380 $\mathrm{nm}$, should not be used due to the high dispersion, which caused by the low signal to noise ratio of these channels. In addition, the AOD from InGaAs channels should be carefully used since they present the highest deviation (apart from the UV channels). An example of the AOD at night-time obtained by the proposed method using CÆLIS is shown in the Figure 8 of González et al. (2020b), where the AOD continuity from day to night-time can be appreciated for different sites and MPA values. 


\subsection{Artículo 2: Correction of a lunar-irradiance model for aerosol optical depth retrieval and comparison with a star photometer}

\subsubsection{Moon vs star photometer}

In order to evaluate the performance of the AOD calculated by the method developed in section 3.2.2.3, the AOD from a Moon photometer has been compared with the AOD measured by a star photometer. To this end, the AOD from the different Moon photometers at UGR station in 2016-2017 has been obtained from CÆLLIS. These AOD data have been previously cloud-screened using the criteria explained in González et al. (2020b), which is similar to the one used at daytime by Giles et al. (2019). The applied criteria are mainly based on: the recorded signal must be higher than a threshold value in some infrared channel (to warranty the correct pointing at the Moon); the AOD variation in a triplet observation must be below a threshold; the temporal variation of AOD at $500 \mathrm{~nm}$ must be smooth (below 0.01 per minute); among others. The AOD negative values, or below a established threshold, have been not discarded in this work, since this kind of criteria are usually based on a threshold marked by the AOD uncertainty, but in this case the uncertainty is still not well known. Finally the cloud-free AOD values from Moon photometer have been averaged in 30 minutes intervals, for comparison purposes with the star photometer outputs, that are $30 \mathrm{~min}$ averaged values (see Section 3.2.2.2.2).

Figure 3.11 shows AODs and AEs for day and night time for the Moon cycle (first to third quarter) in July 2016. Data presented are from Sun photometry (daytime) and Moon and star photometry (night-time). Moon phase angle values are also provided. Generally good day-to-night continuity is observed for different aerosol loads and MPA values. However $\mathrm{AOD}$ at $380 \mathrm{~nm}$ from Moon observations looks noisier, reaching high/low values at the beginning/end of the night (similar to a daytime calibration problem) for the lowest MPA values. The showed data period includes different aerosol episodes, such as Saharan desert dust outbreaks during 18-19 th and 20-21 ${ }^{\text {st }}$ (both events studied by Benavent-Oltra et al. 2019 and Román et al. 2018); the presence of these coarse particles lead to a reduction in the $\mathrm{AE}$ values (calculated only if the 4 wavelengths between 440 and 870 are available), which is also shown in Figure 3.11. The AE from Moon observations fits well between day and night-time even near the Moon quarters, but AE from star measurements presents more fluctuation especially from $22^{\text {nd }}$ to $24^{\text {th }}$ July 2016. These results point out the goodness of the AOD from Moon observations, except at $380 \mathrm{~nm}$ which is not used for AE calculations; however, the fluctuations in AE from star photometer could indicate some extra uncertainties or measurement issues in some channels.

Figure 3.12 shows 1:1 comparisons of Moon photometer AODs and AE versus star photometer values for all data acquired during the intensive field campaigns. All channels show correlation between both AOD data sources, being the correlation coefficient, shown in Table 3.3, higher than 0.96 (0.97 if only 2016 is considered) except for $380 \mathrm{~nm}$, which presents 


\section{RESULTADOS}
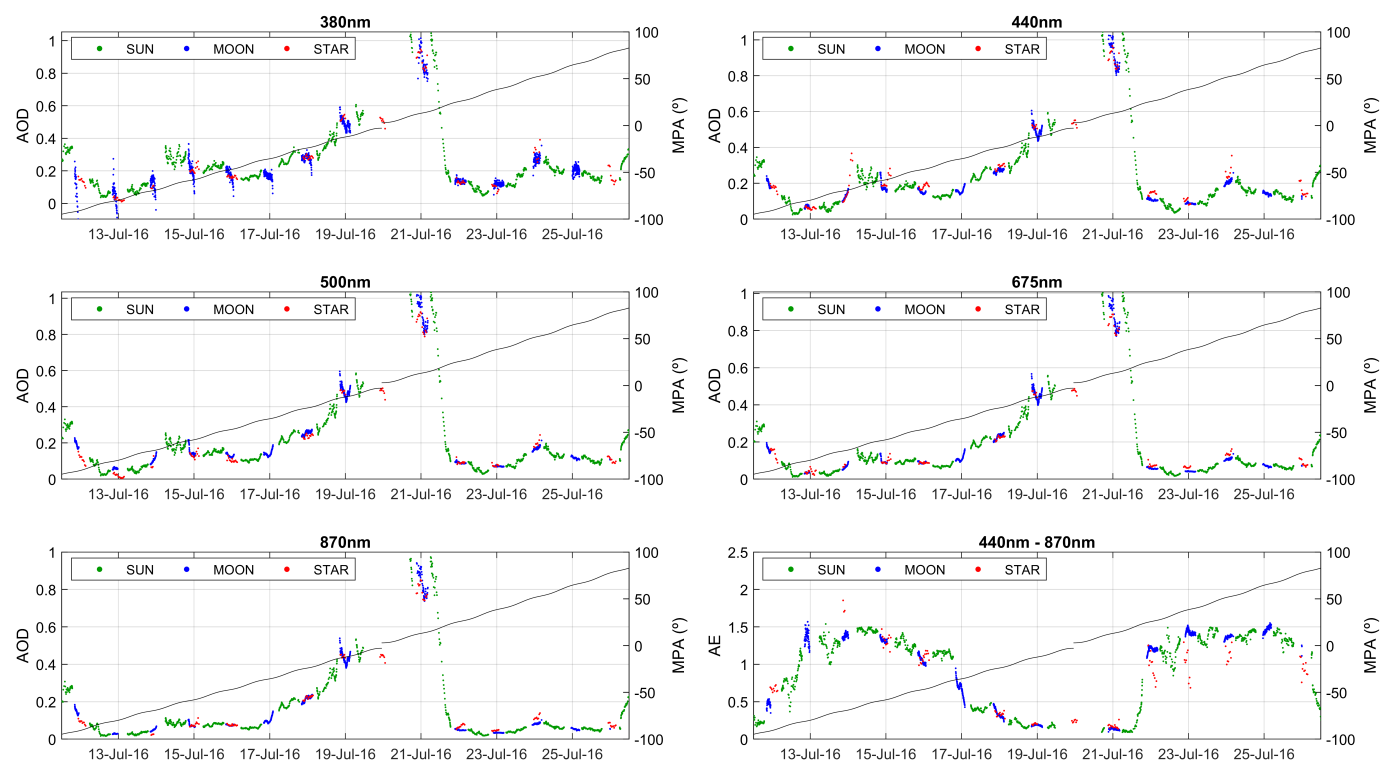

Figure 3.11: Aerosol optical depth (AOD) values from Sun, Moon and star photometer at Granada (Spain) from the first to third Moon quarter in July 2016. Bottom panel at right shows the Ångström Exponent (AE) calculated with the wavelengths of 440, 500 and 675 and $870 \mathrm{~nm}$ (436, 500, 670 and $880 \mathrm{~nm}$ for star photometer). Moon phase angle (MPA) is represented with a black line in each panel.

a lower value around 0.71 . Table 3.3 also shows the slope and y-intercept of the linear fits shown in Figure 3.12, both ranging from $0.975(440 \mathrm{~nm})$ to $1.038(870 \mathrm{~nm})$ and from -0.012 $(870 \mathrm{~nm})$ to $-0.004(500 \mathrm{~nm})$, respectively, for the wavelengths between 440 and $870 \mathrm{~nm}$; these results reveal that the obtained fitted lines are close to the 1:1 line. Table 3.3 also shows the mentioned statistical estimators calculated using only data of 2016 or 2017, separately. For the wavelengths between 440 and $870 \mathrm{~nm}$, the correlation decreases to about 0.94 and the linear fits are farther than the 1:1 line for 2017. This worse relationship between both instruments in 2017 could be caused by some technical problems observed in the star photometer in 2017 after the participation of the instrument in the first multi-instrument nocturnal intercomparison campaign (Barreto et al. 2019) at Izaña, likely linked to the transport of the instrument from Granada to Izaña and vice versa. In the case of the $380 \mathrm{~nm}$, this channel presents higher agreement in 2017 than in 2016 due the large number of negative values of AOD from Moon observations registered in August and September 2016, especially during periods close to the Moon quarters. The AOD data these both months were derived from measurements recorded by the \#751 photometer; AOD from this photometer also showed this behaviour for $380 \mathrm{~nm}$ for all the period of measurements at Granada in 2016 and 2017 (even out of SLOPE campaigns). These values are not cloud-screened because the removal 


\subsection{Artículo 2: Correction of a lunar-irradiance model for aerosol optical depth retrieval and comparison with a star photometer}

of negative AOD values is not included in the screening algorithm. These negative values are the main cause of the shifted linear fit shown in 3.12 for $380 \mathrm{~nm}$. This plot, however, shows that there are many data points of AOD $(380 \mathrm{nnm})$ close to the 1:1 line. In fact, if the agreement in the $380 \mathrm{~nm}$ channel is recalculated without the two mentioned months, the $r$ coefficient, y-intercept and slope are 0.94, -0.03 and 0.97, respectively, using 309 data totally. The behaviour in the agreement of the other channels also shows a little improvement, but in this case it is due to some negative AOD values from star photometer (although within the uncertainties) acquired in August 2016. The same statistical analysis has been done for the AE, showing worse agreement than the AOD. The AE agreement improves if the two troublesome months in 2016 are not included in the analyses. Actually, the improved analysis presents correlation coefficient of 0.79 , slope of 0.85 , and y-intercept of 0.20 . However, removing the most problematic periods, the AE values do not show as good agreement between both instruments as for the AOD, probably because individual deviations in AOD affects AE computations, which is particularly critical for low AOD (Cachorro et al., 2008).

In order to quantify the discrepancies between the AOD retrieved by Moon and star photometers, Figure 3.13 shows frequency histograms of relative differences in AOD, assuming the star photometer as reference. Figure 3.13 reveals that in general the differences are centred around zero and normally distributed. The influence of the negative AOD at 380 from Moon observations can be observed in the negative tail showed by the differences in this channel distribution. The percentage of AOD absolute difference values below 0.02 are $27 \%, 47 \%, 45 \%, 57 \%$ and $63 \%$ for $380,440,500,675$ and $870 \mathrm{~nm}$, respectively; these percentages rise up to $46 \%, 65 \%, 63 \%, 69 \%$ and $75 \%$ for differences below 0.03 . Table 3.3 shows the mean, median and standard deviation of the differences given in Figure 3.13 . For the wavelengths between 440 and $870 \mathrm{~nm}$, the mean and median of the differences are close to zero, being the absolute value below 0.01 except for $440 \mathrm{~nm}$ where the median in all measurement period is -0.012 . These results point out that, for these wavelengths, there is no significant under or overestimation of AOD from Moon to from star photometer, except a very small underestimation about 0.01 at $440 \mathrm{~nm}$ (within the uncertainty). The standard deviation, associated to the uncertainty, shows values about 0.04 for 440 to $675 \mathrm{~nm}$ and 0.03 for $870 \mathrm{~nm}$; these values are reduced around 0.01 if they are calculated only with data from 2017, which can be due to the influence of the mentioned AOD values at August'16. If this month is removed from the dataset, then all the mentioned standard deviations go down to 0.03. The mean, median and standard deviation of the differences in the $380 \mathrm{~nm}$ channel are high, but significantly lower for 2017 likely due to the impact of negative AOD values from Moon observations obtained in the period August-September'16. The median and standard deviation are -0.03 and 0.06 when this period is removed. Regarding AE differences, the 
Table 3.3: Statistical estimators of the differences between the aerosol optical depth (AOD) from Moon and star photometers for different wavelengths and periods. $N$ is the number of used data; $M, M d$ and $S D$ represents the mean, median and standard deviation of these differences, respectively; $y_{0}$, slp and $r$ are the y-intercept, slope and correlation coefficient from the linear fit between the AOD from Moon and star photometers. These estimators are also presented for the Ångström Exponent (AE) in the 440-870 nm range.

\begin{tabular}{ccccccccc}
\hline \hline$\lambda(n m)$ & Period & $N$ & $M$ & $M d$ & $S D$ & $y_{0}$ & $s l p$ & $r$ \\
\hline \hline \multirow{5}{*}{380} & 2016 & 265 & -0.122 & -0.048 & 0.181 & -0.114 & 0.959 & 0.714 \\
& 2017 & 183 & -0.051 & -0.040 & 0.062 & -0.001 & 0.762 & 0.787 \\
& All & 448 & -0.093 & -0.044 & 0.149 & -0.080 & 0.934 & 0.710 \\
\hline \multirow{4}{*}{440} & 2016 & 336 & -0.013 & -0.009 & 0.043 & -0.010 & 0.979 & 0.974 \\
& 2017 & 166 & -0.019 & -0.014 & 0.027 & -0.008 & 0.938 & 0.946 \\
& All & 502 & -0.015 & -0.012 & 0.038 & -0.011 & 0.975 & 0.971 \\
\hline \multirow{5}{*}{500} & 2016 & 304 & 0.006 & 0.008 & 0.040 & 0.005 & 1.007 & 0.978 \\
& 2017 & 162 & -0.025 & -0.024 & 0.031 & -0.013 & 0.926 & 0.918 \\
& All & 466 & -0.005 & -0.003 & 0.040 & -0.004 & 0.997 & 0.969 \\
\hline \multirow{5}{*}{675} & 2016 & 315 & -0.001 & 0.002 & 0.039 & -0.004 & 1.020 & 0.979 \\
& 2017 & 68 & -0.021 & -0.020 & 0.032 & -0.031 & 1.061 & 0.934 \\
& All & 383 & -0.005 & -0.001 & 0.038 & -0.007 & 1.018 & 0.976 \\
\hline \multirow{5}{*}{870} & 2016 & 264 & -0.006 & -0.003 & 0.034 & -0.011 & 1.038 & 0.986 \\
& 2017 & 137 & -0.009 & -0.008 & 0.024 & -0.012 & 1.027 & 0.939 \\
& All & 401 & -0.007 & -0.005 & 0.031 & -0.012 & 1.038 & 0.983 \\
\hline \multirow{4}{*}{ AE(440-870) } & 2016 & 221 & 0.06 & 0.01 & 0.45 & 0.52 & 0.51 & 0.683 \\
& 2017 & 63 & 0.15 & 0.11 & 0.28 & 0.11 & 1.06 & 0.656 \\
& All & 284 & 0.08 & 0.04 & 0.42 & 0.46 & 0.56 & 0.693 \\
\hline \hline
\end{tabular}



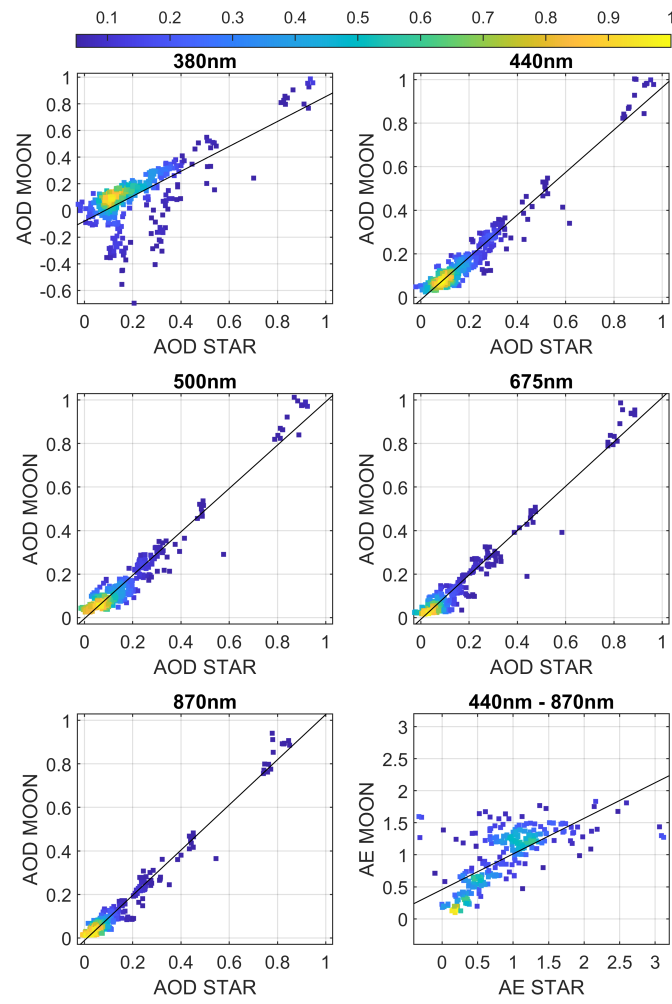

Figure 3.12: Aerosol optical depth (AOD) and Ångström Exponent (AE) from Moon photometer versus the AOD and AE from star photometer for 2016-2017 period and for different wavelengths. Colour legend represents the relative density of data points. Black lines indicate linear fit to the data. 


\section{RESULTADOS}

mean and median are below 0.10 for all data, indicating a lack of significant over or underestimation, but the standard deviation is around 0.4 , revealing a high dispersion.
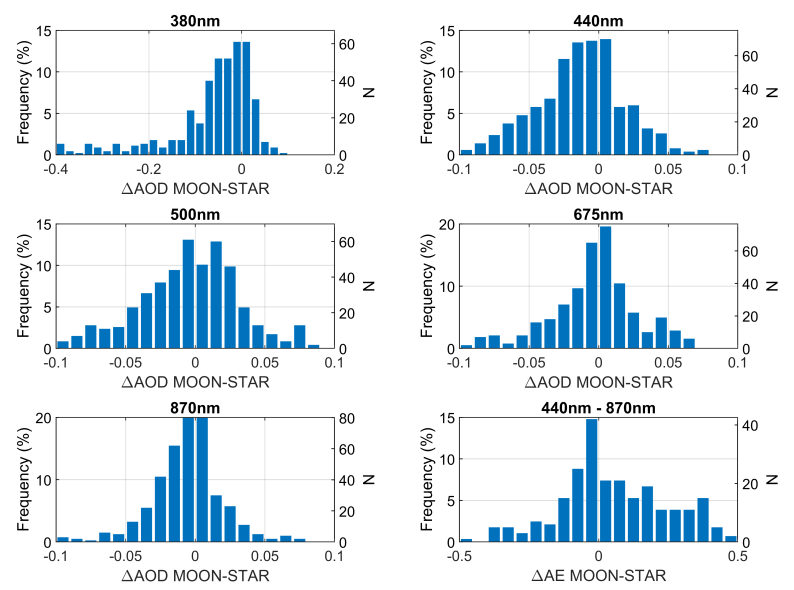

Figure 3.13: Frequency of the aerosol optical depth (AOD) differences between the Moon and star photometers for different wavelengths. Bottom-right panel shows the frequency of these differences for the Ångström Exponent (AE) in the 440-870 nm range.

We have also investigated whether the performance of the AOD depends on the MPA, due to the influence of this parameter on the incoming lunar irradiance and in the RCF values (see Section 3.2.2.3.3). Figure 3.14 shows the Moon-star AOD differences as a function of MPA for the different wavelengths. No dependence of the relative differences on MPA is observed, neither for the median values nor for the standard deviations. A high reduction in the differences can be observed for the $380 \mathrm{~nm}$ in the $70-80^{\circ}$ MPA bin, which surely is the MPA bin with more negative AOD values from Moon observations at this wavelength as mentioned above. Finally, the AE differences do not show any clear pattern with MPA, but the high dispersion observed before can be also appreciated.

\subsubsection{Conclusions}

Moon photometry needs accurate knowledge of the extraterrestrial lunar irradiance in order to calculate the aerosol optical depth (AOD). This paper uses the RIMO model (an implementation of the ROLO model) to calculate this irradiance, and a Sun/sky/Moon photometer (CE318-T) located at the high-altitude station of Izaña to take measurements of the lunar irradiance at ground to derive the AOD. However, the AOD values obtained using these measurements and the RIMO model are not in agreement with the expected values even under pristine and clear conditions. The discrepancies between the obtained and the expected 

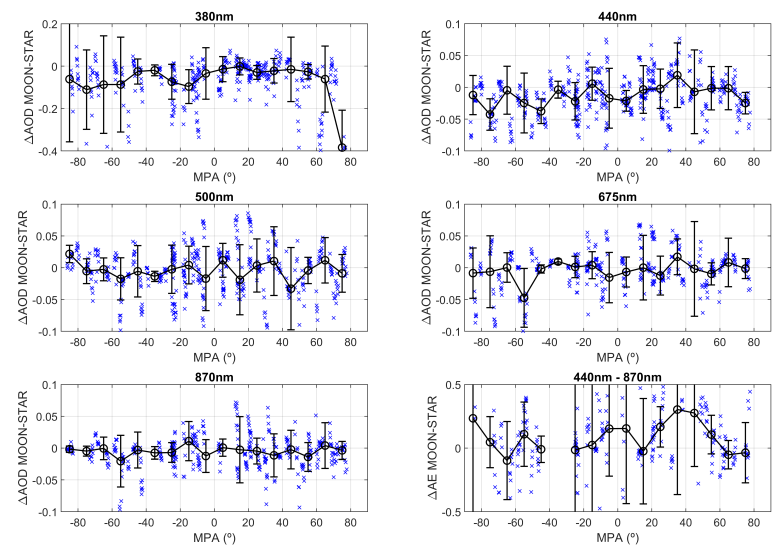

Figure 3.14: Aerosol optical depth (AOD) differences between the Moon and star photometers as a function of Moon phase angle (MPA) for different wavelengths. Bottom-right panel shows these differences for Ångström Exponent (AE) in the 440-870 nm range. Black circles represent the median of all differences in a $\pm 5^{\circ}$ MPA interval, while error bars indicate \pm standard deviation of the data in the same interval.

AOD can be mainly caused by two issues: 1) bad calibration coefficients of the photometer or 2) lack of accuracy in the RIMO values. The calibration used in this work has been based on transferring the calibration of the solar channels (well established) to the Moon channel by a vicarious method, based on the fact that the photometer takes the Moon observations with the same sensor than Sun measurements but with a two-step electronic amplification of 4096 in the signal. In principle, nothing suggests that AOD errors could come from the calibration, while other works in the literature pointed out discrepancies in the ROLO model. This fact has motivated us to assume the lack of accuracy on RIMO as the responsible of the observed differences, and these differences have been used to determine the RIMO accuracy.

Detailed analyses of the differences between expected AOD and the AOD derived by RIMO have shown a bias revealing an underestimation of RIMO to the real extraterrestrial lunar irradiance about $1-14 \%$ for visible and IR channels, which in addition depends on the Moon phase angle (MPA); this result agrees with other works in the literature. The mentioned bias has been modeled as a function of MPA by a 2 nd order polynomial (for each wavelength). These proposed polynomials represent the named RIMO correction factor (RCF), since if a RIMO irradiance output is multiplied by this factor, then the derived AOD from the corrected irradiance will be closer to the expected AOD. The obtained RCF values are at least useful for the retrieval of AOD from Moon observations. Differences around 0.03 in the RCF values has been found for the same wavelength $(1020 \mathrm{~nm})$ using two different detectors (Silicon and InGaAs); this result has apparently no physical sense, since the lunar 


\section{RESULTADOS}

irradiance cannot take two different values for one single wavelength. Consequently, this result must be caused by the uncertainty of the measurements and the method itself, indicating that the uncertainty of the estimated extraterrestrial lunar irradiance with RCF might be about $3 \%$, at least for $1020 \mathrm{~nm}$. The obtained results at $340 \mathrm{~nm}$ have been too noisy hence the use of this channel is not recommended. This new methodology based on the modeled RCF to correct RIMO for AOD calculation has been implemented in CÆLIS, achieving a night-time AOD calculation in near-real time for all photometers managed by this tool in an operational way. This is possible because the used calibration only needs from the routine Sun calibration (the so called Gain calibration method).

The RIMO-corrected AODs have been evaluated versus alternative and independent measurements from a star photometer. This instrument was deployed at Granada, a different location than the one used for the proposed RCF calculation. To our knowledge this is the first long-term AOD comparison between Moon and star observations. The obtained results for wavelengths between 440 and $870 \mathrm{~nm}$ have pointed out a good agreement between both databases, being the absolute mean difference below 0.01 , except for $440 \mathrm{~nm}$ which is below 0.02 . This indicates only a slight underestimation of AOD from Moon to star observations (used as reference) at $440 \mathrm{~nm}$, but within the uncertainty of the star photometer (about 0.02-0.03). The standard deviation of the Moon-star AOD differences for the mentioned wavelengths is about $0.03-0.04$, but if some problematic periods in the star photometer data are neglected, these values are reduced approximately to 0.01 , which leads to an uncertainty in AOD from Moon observations between $0.019(870 \mathrm{~nm})$ and $0.028(500 \mathrm{~nm})$. However, these uncertainties could be lower because part of the observed differences could be caused by: detected technical problems in star photometer filter wheel; the differences in the effective wavelengths used in both instruments and in the way to correct atmospheric gaseous scattering and absorption at these wavelengths; the inhomogeneity of aerosol spatial distribution, since both instruments point to different targets, which also affects to the time interval used to the averages (clouds can block the Moon but not the pointed star, and vice versa). The differences at $380 \mathrm{~nm}$ are higher, showing in the best case an underestimation around 0.03 and an uncertainty about 0.06 . These results suggest current limitations in using this channel, mainly caused by the low signal at this wavelength, which usually produces high dispersion and noisy AOD values close to the Moon quarters. Further improvements and analyses need to be done in order to guarantee AOD quality in the UV region. The analyzed wavelengths have not shown any dependence on MPA in the Moon-star AOD comparison. This is an important result because it indicates that the proposed correction is able to remove any influence of the Moon cycle on the AOD. 


\subsection{Artículo 2: Correction of a lunar-irradiance model for aerosol optical depth retrieval and comparison with a star photometer}

The used night-time cloud-screening is in general the same that is used for daytime but without rejecting AOD values below a given threshold. In spite of providing apparently good results, the night-time cloud-screening is still in development and it could change or add other specific criteria in the future due to the particularities of night-time measurements. The development of new cloud-screening criteria is out of the scope of this paper but, in the future, it could be based on the consideration of temporal smoothness in individual wavelengths or in the addition of a threshold value for the minimum acceptable AOD and for the minimum acceptable recorded signal per channel; this could help to warranty the AOD quality, especially in the noisier channels like $380 \mathrm{~nm}$. Recently, AERONET is also providing AOD values from Sun/sky/Moon photometers with its own method ${ }^{1}$, but this product is still labeled as provisional at present, hence a direct comparison between the AOD from the proposed and the AERONET methods has not been considered.

To sum up, this work provides more evidences about the reported underestimation of RIMO/ROLO model to the real extraterrestrial lunar irradiance and points to the need for a correction of this model or the development of a new extraterrestrial lunar irradiance model, at least for accurate AOD calculation purposes. Meanwhile, at least until a more accurate lunar irradiance model is available, the proposed correction can help in providing AOD retrievals with the Moon. Moreover, additional studies using different Moon photometer/spectroradiometer models or using alternative and independent night-time instrumentation, like lidar or star photometers, are highly recommended to characterize the AOD uncertainty, the accuracy of the proposed method and the feasibility of its use with other instrumentation.

Data availability. The used data are available from the authors upon request

Author contributions. RR, RG and CT designed and developed the main concepts and ideas behind this work and wrote the paper with input from all authors. RG, AB and RR implemented the RIMO model in CÆLIS. RR, JABO and DPR carried out the routine and calibration measurements of the star photometer. DPR computed and processed the AOD data from the star photometer. VEC, FJO, LAA and AMdF aided in interpreting the results and worked on the manuscript. All authors were involved in helpful discussions and contributed to the manuscript.

Competing interests. The authors declare that they have no conflict of interest.

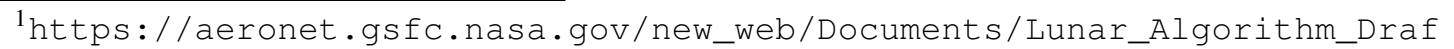
t_2019.pdf|https://aeronet.gsfc.nasa.gov/new_web/Documents/Lunar_Algorith m_Draft_2019.pdf 


\section{RESULTADOS}

Acknowledgements. The authors are grateful to the Spanish Ministry of Science, Innovation and Universities for the support through the ePOLAAR project (RTI2018-097864-BI00). This work was also supported by the Spanish Ministry of Economy and Competitiveness through projects CGL2016-81092-R, and CGL2017-90884-REDT; by the Andalusia Regional Government through project P18-RT-3820; and by the European Union's Horizon 2020 research and innovation program through ACTRIS-IMP (grant agreement No 871115). We thank Emilio Cuevas and their staff for establishing and maintaining the Izaña station used in this investigation.

\section{References}

See references section of the $\mathrm{PhD}$ Thesis. 


\subsection{Artículo 3: Characterization of stratospheric smoke par- ticles over the Antarctica by remote sensing instruments}

\subsubsection{Resumen y comentarios}

Durante los días del 7 al 10 de enero de 2020 se observaron valores extraordinariamente elevados de espesor óptico de aerosoles (AOD) en la estación de medida de Marambio, en la Antártida Argentina. El AOD en 500 nm llegó a alcanzar valores en torno a 0.3 el día 9 de enero y, en general, los valores de AOD fueron mucho más altos en el el periodo señalado que los valores medidos en la misma estación desde que se dispone de medidas; nunca se había superado un valor diario de AOD en $500 \mathrm{~nm}$ de 0.1 .

Una vez detectados estos valores se procedió a identificar el tipo de aerosol que llegó a Marambio, así como su origen. Para ello se han utilizado diferentes técnicas. La altura a la que se encontraba el aerosol detectado ha sido determinada gracias a los datos de CALIOP/CALIPSO, los cuales indican que esta altura estuvo alrededor de $13 \mathrm{~km} \mathrm{snm}$. Con esta información se han calculado las retrotrayectorias de las masas de aire a $13 \mathrm{~km}$ snm sobre Marambio utilizando el modelo HYSPLIT, las cuales revelan que el aerosol venía del sureste de Australia. Este resultado parece indicar que el aerosol que se detectó en Marambio tuvo su origen en la intensa quema forestal que se produjo durante los incendios ocasionados al este de Australia a finales de 2019. El origen en estos incendios ha sido confirmado por los datos de "Aerosol Index" del satélite Suomi-NPP, los cuales revelan que los incendios al sur de Australia inyectaron una fuerte cantidad de partículas de humo en la estatosfera a través de pirocumulonimbos; este humo cruzo el océano Pacífico hasta alcanzar la Antártida varios días después.

Una vez identificada la fuente de arosoles, así como su transporte, se ha realizado un análisis de la variación de las propiedades del aerosol desde su origen, utilizando datos de una estación en Australia, hasta su llegada a Marambio. Los resultados indican que el aerosol que llegó a Marambio fue humo "envejecido", el cual difiere ligeramente del aerosol que salió de Autralia que puede catalogarse como humo "fresco". Los valores diarios de AOD en $500 \mathrm{~nm}$ obtenidos los meses después del evento descrito fueron ligeramente más altos que los observados los años anteriores; esto parece indicar que partículas de humo estuvieron todavía presentes sobre la Antártida incluso durante mucho tiempo después del evento mencionado.

Esté trabajo arroja la evidencia de lo importante que es tener algoritmos como el que calcula el AOD corriendo de forma rutinaria para poder detectar estos eventos en tiempo cuasi-real. 


\title{
3. RESULTADOS
}

A continuación, se puede ver en detalle todo el proceso de identificación y caracterización del aerosol.

\subsubsection{Characterization of stratospheric smoke particles over the Antarc- tica by remote sensing instruments}

Ramiro González ${ }^{1 *}$, Carlos Toledano ${ }^{1}$, Roberto román ${ }^{1}$, David MAteos ${ }^{1}$, Eija Asmi ${ }^{2,3}$, Edith Rodríguez $^{2}$, Ian C. Lau ${ }^{5}$, Jonathan Ferrara ${ }^{3}$, Raúl D’elia ${ }^{5}$, Juan Carlos Antuña-Sánchez ${ }^{1}$, Victoria E. Cachorro ${ }^{1}$, Abel Calle ${ }^{1}$, and Ángel M. de Frutos ${ }^{1}$

${ }^{1}$ Group of Atmospheric Optics, University of Valladolid (GOA-UVa), Valladolid, Spain;

${ }^{2}$ Finnish Meteorological Institute, Helsinki, Finland;

${ }^{3}$ National Meteorological Service, Buenos Aires, Argentina;

${ }^{4}$ Commonwealth Scientific and Industrial Research Organisation (CSIRO) Mineral Resources, Kensington, Australia;

${ }^{5}$ CEILAP - UNIDEF (CITEDEF-CONICET), Villa Martelli, B1603ALO, Buenos Aires, Argentina ;

*Correspondence: ramiro@goa.uva.es

\begin{abstract}
Australian smoke from the extraordinary biomass burning in December 2019 has been observed over Marambio, Antarctica, on 7th-10th January, 2020. The smoke plume was transported thousands of kilometers over the Pacific Ocean, and reached the Antarctic Peninsula at $13 \mathrm{~km}$ height, as determined by satellite lidar observations. The proposed origin and trajectory of the aerosol are supported by back-trajectory model analyses. Groundbased Sun-Sky-Moon photometer belonging to the Aerosol Robotic Network (AERONET) measured aerosol optical depth (500 $\mathrm{nm}$ wavelength) above 0.3 , which is unprecedented for the site. Inversion of sky radiances provide the optical and microphysical properties of the smoke over Marambio. The AERONET data near the fire origin in Tumbarumba, Australia, was used to investigate the changes in the measured aerosol properties after transport and ageing. The analysis shows an increase in the fine mode particle radius and a reduction in absorption (increase in the single scattering albedo). The available long-term AOD data series at Marambio suggests that smoke particles could have remained over Antarctica for several weeks after the analyzed event.
\end{abstract}

Keywords: Antarctica; aerosol; optical properties; biomass burning, Australian fires, smoke ageing 


\subsubsection{Introduction}

Antarctica is the most isolated and pristine continent. Studies about Antarctic aerosols started in the 1960's, both with remote sensing and in situ techniques Kuhn (1972); Voskresenskii (1968). Those first measurements indicated the presence of sulfate, sea salt and crustal aerosols. Despite the very low concentrations, the presence of extraneous particles proves that aerosol transport takes place on a global scale Shaw (1988). Coarse sea salt particles dominate the aerosol mass over Antarctica, especially in coastal areas. The main sources of secondary aerosol (fine mode) over Antarctica are the marine sulphur and organic aerosol precursors Asmi et al. (2010). A significant fraction of fine mode of Antarctic aerosol might originate from a source not yet identified Giordano et al. (2017). The absorption is a key parameter to determine the aerosol radiative effect Myhre (2009). Significant black carbon concentrations were measured in Antarctica, with the main sources suggested to be biomass burning aerosols transported from South-America, Africa and Australia Asmi et al. (2018); Fiebig et al. (2009).

In the Antarctic Peninsula, severe environmental changes in the past decades are likely linked to natural variability (changes in atmospheric circulation, local sea-ice loss), although other processes with anthropogenic origin like the ozone depletion may have played a role too. As a result, some of the largest increases in near-surface air temperature in the Southern Hemisphere in the $20^{\text {th }}$ century were registered in the Antarctic Peninsula Turner et al. (2016). Long-term observations are needed to establish whether and how these changes can affect the aerosol amount and properties in the region Asmi et al. (2018).

Long range transported aerosol from biomass burning affects polar regions, especially the Arctic Graß 1 and Ritter (2019); Ranjbar et al. (2019); Ritter et al. (2018); Saha et al. (2010); Tomasi et al. (2007); Zielinski et al. (2020), but also Antarctica Fiebig et al. (2009); Stohl and Sodemann (2010); Weller et al. (2013). The occurrence of bushfires is likely to increase due to climate change Dowdy et al. (2019); IPCC (2014) and thus the occurrence of aerosol events caused by long-range transported smoke over polar regions. The aerosol optical properties of the transported aerosol, thus its radiative effects, are largely uncertain. Ageing processes during transport affect the size, shape and absorption properties of the smoke particles Baars et al. (2019); Eck et al. (2003); Reid et al. (2005). Other important aerosol effects are the deposition on snow and ice, and the interaction with clouds Asmi et al. (2018); Shaw (1988).

In January 2020, bushfires in Australia burned over 20,000 ha $\left(2 \times 10^{8} \mathrm{~m}^{2}\right)$ of land and injected large amounts of smoke into the atmosphere Boer et al. (2020). The MetService at New Zealand reported a huge smoke plume that was transported 2,000 km across the Tasman Sea and reached the lower South Island, which reduced visibility and produced red skies. 


\section{RESULTADOS}

Satellite imagery revealed the plume extension, and the World Meteorological Organization reported the transport of the smoke across the Pacific Ocean to South America, and that smoke had 'probably' reached Antarctica (https://public.wmo.int/en/media/ news/australia-suffers-devastating-fires-after-hottest-driestyear-record). The Australian Bureau of Meteorology reported in spring 2019 the highest fire weather danger that was measured by the Forest Fire Danger Index across the whole Australia Bureau of Meteorology (2019). A detailed and qualitative satellite analysis about bushfires in Australia from September 2019 to January 2020 can be found at https : / / worldv iew.earthdata.nasa.gov/?tr=australia_fires_2019_2020 and https: //asdc.larc.nasa.gov/news/new-storymap-studying-the-2019-2020australian-bushfires-using-nasa-data.

Recent studies have thoroughly described this smoke event Kablick III et al. (2020); Khaykin et al. (2020). The smoke generated Pyro-cumulonimbus (pyroCb) clouds that caused unprecedented stratospheric perturbations, similar to those caused by moderate volcanic eruptions Khaykin et al. (2020). In particular, it was observed the generation of potential vorticity and anticyclonic circulations caused by absorptive aerosol heating Kablick III et al. (2020). The paths and extension of several stratospheric smoke plumes are described in detail. The main plume generated a self-maintained anticyclonic vortex measuring 1000 $\mathrm{km}$ in diameter, that ascended during three months until it reached $35 \mathrm{~km}$ height; it lofted a confined bubble of carbonaceous aerosols and water vapour that travelled westbound roundthe-world over $66,000 \mathrm{~km}$, until the beginning of April 2020 Khaykin et al. (2020). Both works explicitly indicate that a smoke patch was transported over Antarctica and remained there for several weeks. The smoke over Antarctica generated a weaker vortex but was subject to strong aerosol heating due to the permanent daylight and rose up to $27 \mathrm{~km}$ Kablick III et al. (2020); Khaykin et al. (2020). Another recent study based on LIDAR observations at Punta Arenas, Chile, confirms the transport of the smoke at stratospheric levels over South America, and provides optical properties such as optical depth, lidar ratio and depolarization ratio Ohneiser et al. (2020).

Ground based remote sensing instruments like the AErosol RObotic NETwork (AERONET) photometers Holben et al. (1998) are globally deployed in order to assess aerosol properties. The Group of Atmospheric Optics at the University of Valladolid (GOA-UVa), in collaboration with the Finnish Meteorological Institute and the National Weather Service in Argentina, installed in 2018 an AERONET Sun/sky/Moon photometer at Marambio station, located in the Antarctic Peninsula. This instrument detected an extraordinary and unprecedented aerosol event over Marambio on 7th-10th January 2020, with record values of aerosol optical depth (AOD), and optical properties that indicate the presence of aged smoke aerosol 
particles. The aim of this paper is to assess the origin of this aerosol event and characterize the optical and microphysical properties of the aerosols.

\subsubsection{Sites and instrumentation}

\subsection{Measurement stations}

Marambio is an Argentinian Antarctic station located in the ice-free Seymour-Marambio island, at the north-east tip of the Antarctic Peninsula $\left(64.240^{\circ} \mathrm{S}, 56.625^{\circ} \mathrm{W}\right.$ and $200 \mathrm{~m}$ a.s.1., see Figure 3.15). Marambio is characterized by a permafrost ecosystem. The Antarctic region has no permanent human habitation but Marambio station operates all-year round and acts as a logistic center for the scientific projects and also for other Argentinian Antarctic stations. There are around 40-70 persons in Marambio even in austral winter Asmi et al. (2018). The temperature at Marambio varies between $+10^{\circ} \mathrm{C}$ in summer and $-30^{\circ} \mathrm{C}$ during winter. However the wind speed can reach $100 \mathrm{~km} / \mathrm{h}$ decreasing the apparent temperature to $-60^{\circ} \mathrm{C}$. The strong winds can blow snow and dust (in winter or summer) into the air. The prevailing wind directions are southwest and northwest (Asmi et al., 2018).

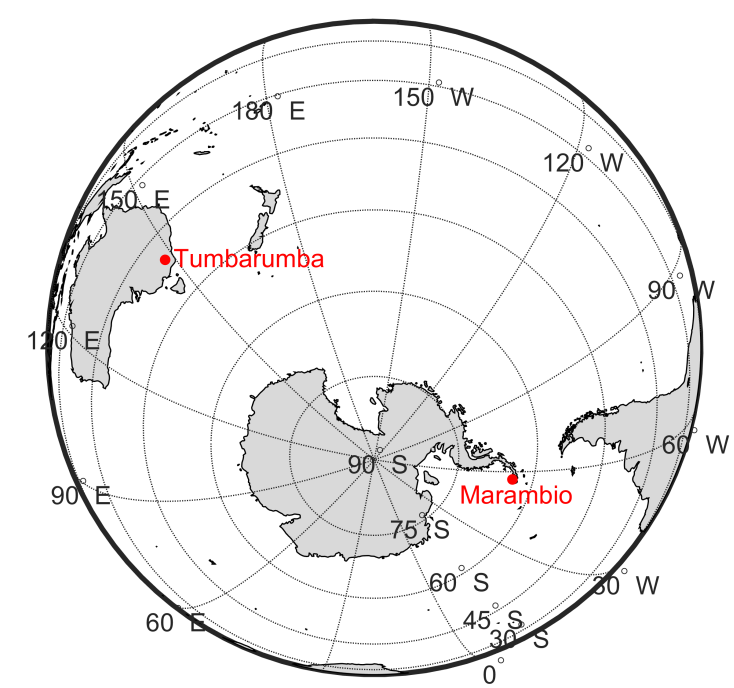

Figure 3.15: Location of the Marambio station (Antarctica) and Tumbarumba AERONET station (Australia).

In January 2018 the GOA-UVa installed a Sun/sky/Moon photometer CE318-T (Cimel Electronique S.A.S.) and an OMEA 3C all-sky camera (Alcor System) in Marambio station. This instrumentation is installed on the rooftop of the Scientific Laboratory, which is located 


\section{RESULTADOS}

in the middle of the station, between the the airfield and station buildings. This laboratory belongs to the Argentinian National Meteorological Service (Servicio Meteorológico Nacional) and is shared with the Argentinian National Direction of the Antarctic (Dirección Nacional del Antártico). The laboratory's rooftop is also equipped with instrumentation focused on atmospheric studies by different techniques, e.g. a Precision Filter Radiometer (PFR), a Vaisala Ceilometer, Brewer spectroradiometer, MAX-DOAS, to cite some. In addition, several aerosol in-situ instruments, which belong to the Finnish Meteorological Institute (FMI), installed since January 2013, are located in a container $300 \mathrm{~m}$ away from the main site (Asmi et al., 2018).

In order to identify the bushfire aerosol properties near its source, we used an AERONET station located in the vicinity of the bushfires in Australia. The Tumbarumba AERONET site $\left(35.708^{\circ} \mathrm{S}, 147.950^{\circ} \mathrm{E}\right.$ and $776 \mathrm{~m}$ a.s.1.), located at the south-east of Australia (see Figure 3.15), is equipped also with a Sun/sky/Moon photometer CE318-T photometer since July 2019. The Sun photometer is located on top of a rounded hill in cleared land used for grazing of cattle. Native eucalypt woodland is located to the west and south east. The area suffered a large bush fire in December 2019-January 2020, known as the Dunns Road Bushfire. Native forest and grazing paddocks burnt within $10 \mathrm{~km}$ of the site. A flux tower, with CSIRO instrumentation located $20 \mathrm{~km}$ to the north east in the Bago State Forest was damaged when the ground infrastructure was burnt. At this site, persistent high values of aerosol optical depth were detected for several weeks (data are available in the AERONET website).

\subsection{Instruments and data}

The Cimel CE318-T is designed to measure at filter-selected wavelengths the direct Sun and Moon irradiance, and the diffuse sky radiance. These measurements are useful to retrieve different aerosol properties (Barreto et al., 2016; Dubovik and King, 2000; Shaw, 1983). The Cimel radiometer is the reference instrument of AERONET. See Giles et al. (2019); Holben et al. (1998) for details about the instrument, data processing and calibration. The generated data are public and can be freely downloaded from the AERONET website (ht tps://aeronet.gsfc.nasa.gov). The GOA-UVa is responsible of an AERONET calibration center located in Valladolid, Spain, in cooperation with NASA, the University of Lille and the Spanish Meteorological Agency. The CÆLIS software tool was developed for the management of this calibration center and instrument monitoring (Fuertes et al., 2018, González et al., 2020b; Román et al., 2020). This tool allowed for quick detection of the event as well as assisted in the routine monitoring of the CE318-T instrument performance at Marambio. This operational aspect is crucial in polar regions. 
In this paper we have used the AERONET version 3 level 1.5 (cloud-screened) aerosol products of: AOD at 340, 380, 440, 500, 675, 870, 1020 and $1640 \mathrm{~nm}$ (Giles et al., 2019), which is derived from Sun/Moon direct irradiance measurements; aerosol particle size distribution and single scattering albedo (SSA) at 440, 675, 870 and $1020 \mathrm{~nm}$, both retrieved by the AERONET operational inversion code using as input the multi-wavelength AOD and sky radiance measurements taken at almucantar and hybrid geometry (Dubovik and King, 2000; Sinyuk et al. 2020); and the AOD fine mode fraction at $500 \mathrm{~nm}$, which was calculated by the spectral deconvolution algorithm (SDA) (ONeill et al. 2003). A set of quality criteria was applied to ensure the reliability of the inversion data, i.e. solar zenith angle $>50^{\circ}$ (for almucantar scans), minimum number of symmetrical angles and retrieval error between 5\% and 8\% depending on AOD Toledano et al. (2019). The Ångström exponent (AE), which represents the AOD spectral variation and contains information about the aerosol size predominance, has been calculated by a least square fit of the AERONET AOD values in the spectral range from 440 to $870 \mathrm{~nm}$. Concerning the inversion products, the fine and coarse modes are separated at the inflection point within the radius interval 0.439-0.992 $\mu m$. The size distribution parameters (median and effective radius, volume concentration) are provided for each mode.

In order to identify the height of the aerosol layers, vertical profiles of total attenuated backscatter at $532 \mathrm{~nm}$ have been obtained from CALIOP (Cloud-Aerosol Lidar with Orthogonal Polarization) for the Antarctica overpass of the CALIPSO (Cloud-Aerosol Lidar and Infrared Pathfinder Satellite Observations) satellite (Winker et al., 2009). These data belong to the CALIPSO Lidar Level 1 V4.10 product (CAL_LID_L1-Standard-V4-101).

The Aerosol Index -PyroCumuloNimbus- (AI-PCN) product (Torres, 2019), from the Ozone Mapping Profiler Suite (OMPS) instrument on board the joint NASA/NOAA Suomi National Polar-orbiting Partnership (NPP) satellite (Flynn et al., 2014), has been used to track the spread of high aerosol concentrations in the atmosphere. This satellite product is based on the detection of absorbing particles in the ultraviolet region. The aerosol index is derived from normalized radiances using 2 wavelength pairs at 340 and $378.5 \mathrm{~nm}$. This product is linked to both the thickness and the height of the aerosol layer located in the atmosphere.

In addition, airmass back-trajectories at Marambio have been obtained from the National Oceanic and Atmospheric Administration (NOAA) Air Resources Laboratory's (ARL) Hybrid Single-Particle Lagrangian Integrated Trajectory (HYSPLIT) model (Stein et al., 2016).

1 https://www-calipso.larc.nasa.gov/products/lidar/browse_images/std_v 4_index.php 


\section{RESULTADOS}

HYSPLIT has been run with the trajectory ensemble option; this option starts multiple trajectories from the starting location. Each member of the trajectory ensemble is calculated by offsetting the meteorological data by a fixed grid factor, resulting in 27 members for all-possible offsets in $\mathrm{X}, \mathrm{Y}$, and $\mathrm{Z}^{1}$

\subsubsection{Smoke event detection over Marambio}

On 7th January, 2020 the aerosol optical depth at Marambio raised from values below 0.05 to higher than 0.2 (at $500 \mathrm{~nm}$ ), as can be observed in Figure 3.16a. The AOD on 8th Janaury is not available due to cloudiness, but the AOD on the 9th was even higher, about 0.3 at 500 $\mathrm{nm}$. The AOD decreased on 10th January to AOD values below 0.05 at $500 \mathrm{~nm}$ at the end of the day. The AE values from 7th to 10th January were about 1.3, i.e. it was lower than the AE observed before and after the event (about 1.6). However the fine mode AOD shown in Figure 3.16b considerably increased during the mentioned event, indicating fine particle predominance, especially on 9th January, whereas the coarse mode AOD was constant and stable for all the shown days. Figure 3.16 shows that the fine mode fraction of the AOD $(500 \mathrm{~nm})$ was larger than $90 \%$ from 7 th to 10th January and nearly $100 \%$ on 9th January. The fine mode fraction is still above $85 \%$ on the 6th and 11 st January, but below $85 \%$ on 5 th and 12nd January. These results indicate the presence of a fine particle event over Marambio from 7 th to 10 th January.

The height of the aerosol layer over Marambio could provide additional information about its origin. Figure 3.17 shows the vertical attenuated backscatter profiles at $532 \mathrm{~nm}$ for selected CALIOP/CALIPSO overpasses close to Marambio during the analysed event. A weak layer around $13 \mathrm{~km}$ asl was detected over Marambio at the beginning of 7th January 2020. A stronger layer can be seen over Marambio on the 8th, 9th and 10th January 2020 at the same height. Another layer around $15 \mathrm{~km}$ asl is frequently visible on those days. All these observed high altitude layers over Marambio presented lower total attenuated backscatter at $1064 \mathrm{~nm}$ compared to $532 \mathrm{~nm}$ (not shown), and an attenuated color ratio (backscatter at $1064 \mathrm{~nm} /$ backscatter at $532 \mathrm{~nm}$ ) in general about 0.4-0.6.The depolarization ratio at 532 nm CALIOP product was mostly between 0.0 and 0.2 for the marked layers. They were generally classified as 'stratospheric aerosol' by the CALIOP vertical feature mask product (Version 4.20). The aerosol subtype CALIOP product (Version 4.20) identifies these layers mostly as 'elevated smoke'.

In order to detect the origin of the analyzed aerosol event, ensemble HYSPLIT trajectories running for 240 hours backwards and ending at $13 \mathrm{~km}$ asl over Marambio (the observed height of the aerosol layer) have been computed. These backtrajectories are shown in Figure

\footnotetext{
${ }^{1}$ https://www.ready.noaa.gov/hypub-bin/trajtype.pl
} 


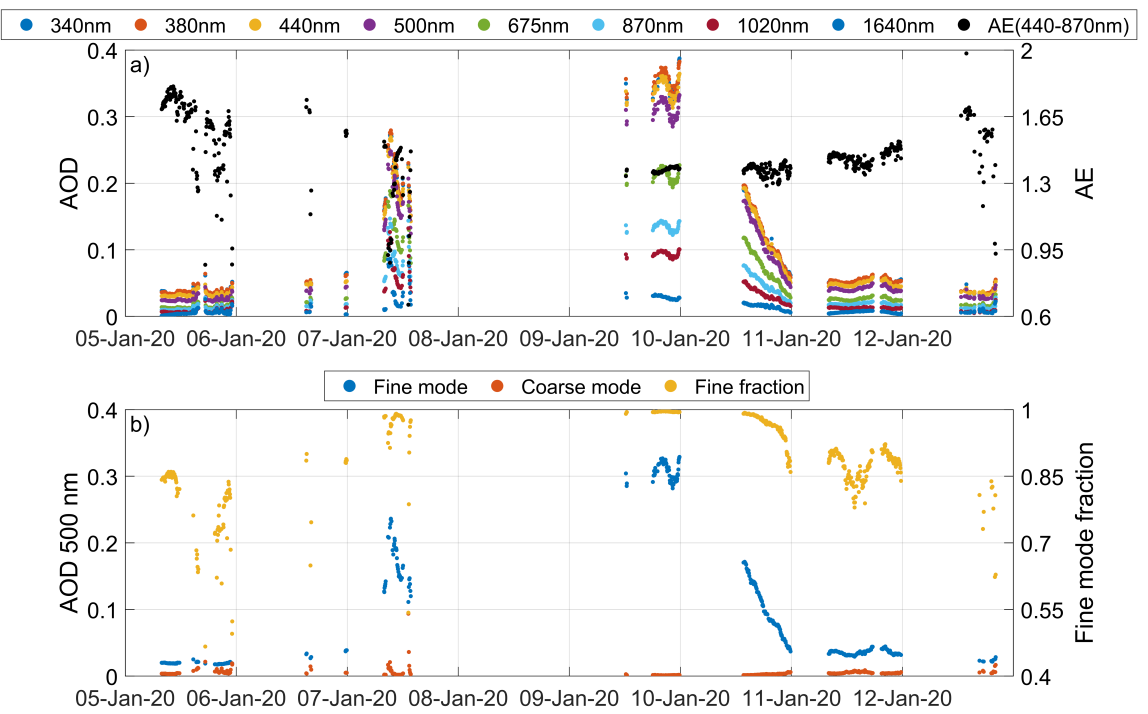

Figure 3.16: (a) Aerosol optical depth (AOD) for different wavelengths and Ångström exponent (AE) at Marambio on 5-12th January 2020. (b) Fine and coarse mode aerosol optical depth at $500 \mathrm{~nm}$ and the fine mode fraction at Marambio on 5-12th January 2020.

3.18 for the days from 6th to 11th January, at 12:00 UTC. The air masses at $13 \mathrm{~km}$ altitude over Marambio came mainly from the middle of South Pacific ocean area (origin at about $15 \mathrm{~km}$ asl) for the aerosol event days (7th-10th January 2020), with some of the ensemble computations originating in Southeastern Australia. This supports our hypothesis that the detected aerosol could be smoke that originated in the bushfires of Australia austral summer 2020. Similar layer structure and heights were found by Ohneiser et al. (2020) over Punta Arenas, Chile, where the smoke plume was detected by means of a ground-based lidar, and HYSPLIT backtrajectories indicate that it originated in the Australian bushfires. The backtrajectories on 6th and 11th January have a different origin than they show during the event, crossing the Southern Ocean and Antarctic Peninsula areas.

The AI-PCN from OMPS/NPP satellite is shown in Figure 3.19 for several days between 28 December 2019 and 11th January 2020 over the South Pacific Ocean. This product, as well as True Color corrected reflectance for all days from 10th December 2019 to 13th January 2020 and corresponding animations, can be found as supplementary material to this paper. The AI-PCN in Figure 3.19 shows aerosol load appearing over southeastern Australia on 28th (and 29th, not shown) December, 2019, as a consequence of massive bushfires. CALIOP/CALIPSO data on 31st December (not shown) reveal that this aerosol was injected up into the stratosphere to $13-15 \mathrm{~km}$ height Kablick III et al. (2020), similar to the case reported by Peterson et al. (2018) for wildfire-driven thunderstorms (pyro-cumulonimbus). 


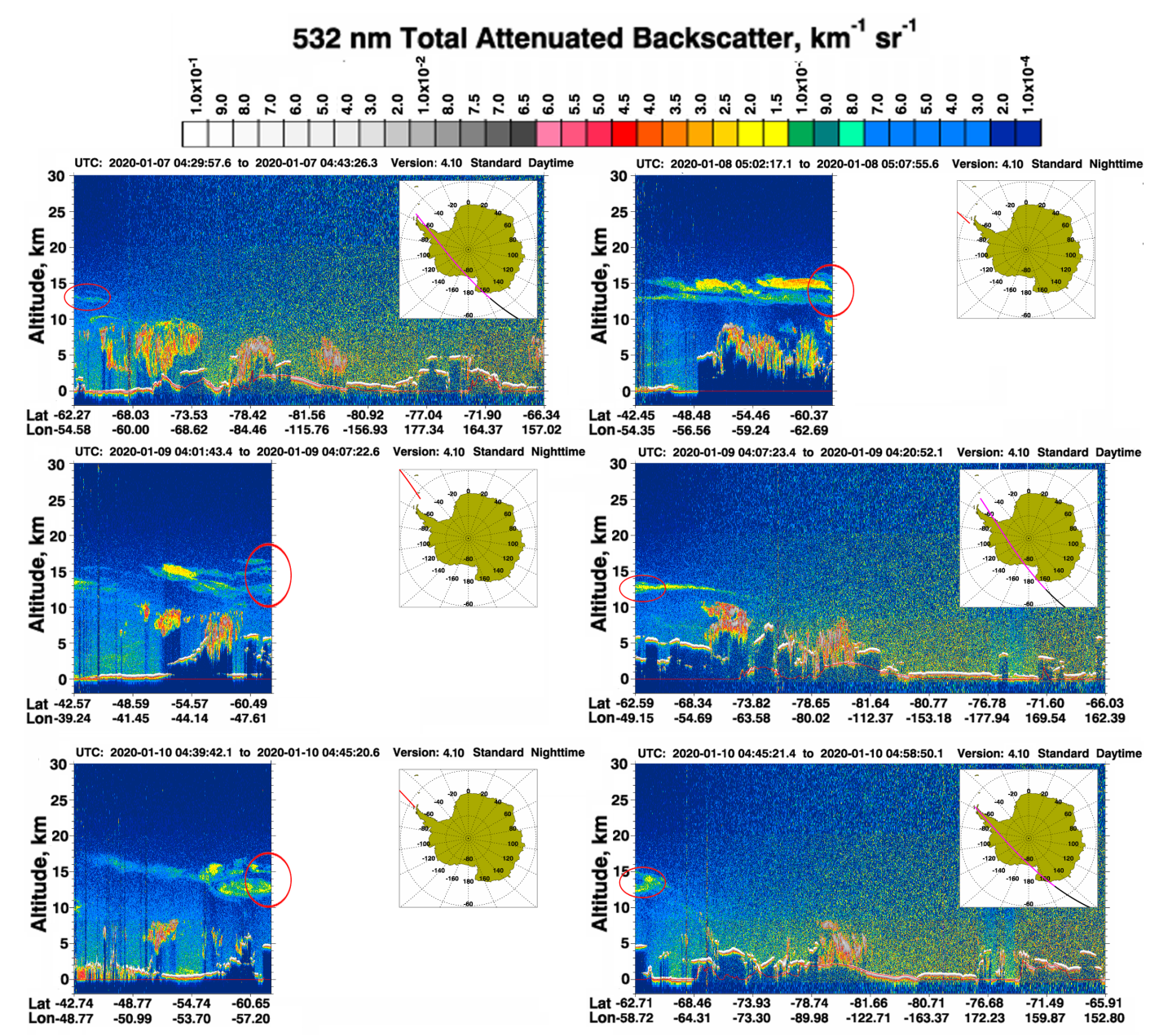

Figure 3.17: Vertical profiles of total attenuated backscatter at $532 \mathrm{~nm}$ from CALIOP/CALIPSO overpasses. The profiles are shown for six different overpasses from 7th to 10th January 2020. The highest aerosol layers close to Marambio location are marked with a red circle. 

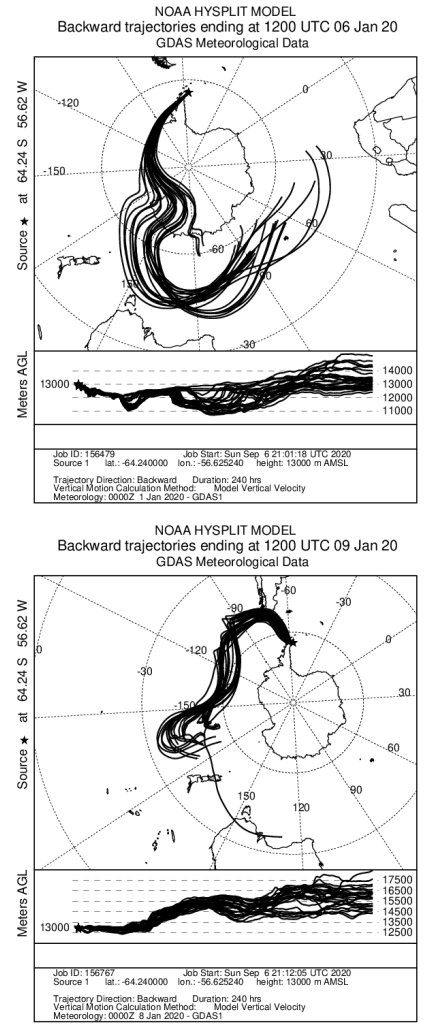
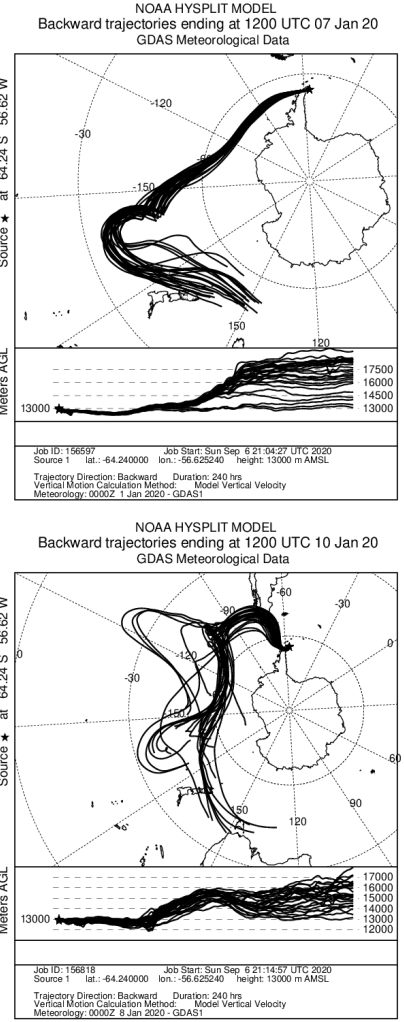

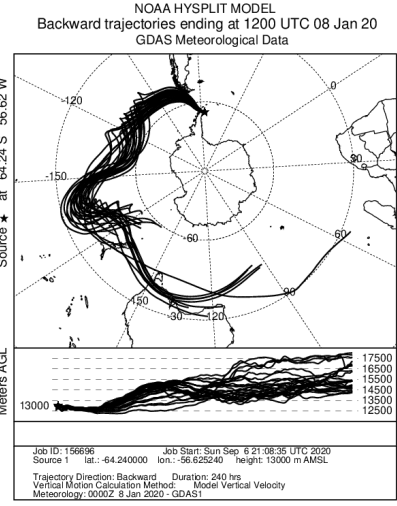

NOAA HYSPLIT MODEL
Backward trajectories ending at 1200 UTC 11 Jan 20

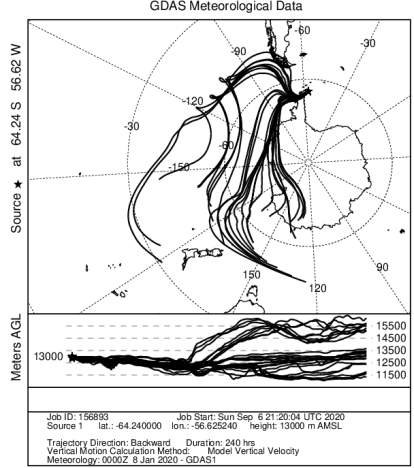

Figure 3.18: Ensemble HYSPLIT 10-days back-trajectories computed from Marambio at $13 \mathrm{~km}$ asl from 6th to 11st January 2020. 


\section{RESULTADOS}

From 30th December 2019 to 1st January 2020 the aerosol plume was transported eastwards, crossing over New Zealand (see Figure 3.19) at around $15 \mathrm{~km}$ asl as indicated by CALIOP (not shown). The following days the plume was transported over the Pacific Ocean. A detailed description of this smoke plume as well as subsequent plumes is provided by Kablick III et al. (2020); Khaykin et al. (2020). Some smoke patches escaped from the vortex and moved eastwards. For instance, two plumes travelled to the south and the center of South-America on 5th January 2020. The first one reached southern Argentina and Chile on 6th January, and approached to Marambio on 7th January. The aerosol plume stayed over Marambio area from 8th to 10th January and moved towards Northeast on 11th January. For details, see Aerosol Index animation provided as supplementary material to this paper, as well as the supplementary information to (Kablick III et al., 2020, S2 animation). This aerosol transport from Australia to Marambio was additionally confirmed by the MODIS (Moderate Resolution Imaging Spectroradiometer) AOD data and NAAPS (Navy Aerosol Analysis and Prediction System) model (see supplementary material), providing further evidence that the aerosol plume detected over Marambio originated in the bushfires in Australia, and was transported more than 10,000 km over the Pacific Ocean.

\subsubsection{Aerosol properties}

The scatter plot between Ångström exponent and aerosol optical depth can be used to classify the aerosol (e.g. Holben et al., 2001; Toledano et al., 2007). In this plot, the horizontal axis indicates the daily AOD whereas the vertical axis indicates the AE, related to the size predominance (larger size for lower AE). The AERONET data collected at Marambio until now, are depicted in Figure 3.20. They include summer campaigns in 2008 and 2009 performed by CEILAP-UNIDEF (National Scientific and Technical Research Council, Argentina) and routine measurements since January 2018. These data indicate very low AOD with average of 0.038 at $500 \mathrm{~nm}$, and relatively high and variable AE $(440-870 \mathrm{~nm})$ in the range 1.0 to 2.5 , with overall mean of 1.38 (median 1.33). This can be considered the background aerosol at the site. Only occasionally ( $11 \%$ of the days) the AE is below 1.0, indicating in these cases the predominance of coarser (possibly marine) particles. Similar AOD values are reported by Tomasi et al. (2015) for the GAW-PFR observations at Marambio in 2011-2013.

The three investigated days (7th, 9th and 10th January 2020) have the highest AOD daily means of the entire data set. Until this episode, AOD had not exceeded 0.1 (at $500 \mathrm{~nm}$ wavelength), clearly showing that this event was extraordinary at the site. Moreover, the AOD daily mean values of AOD after the event (until April 2020), marked in red color in Figure 3.20, are consistently above the background values, suggesting that some residual aerosol could be present in the atmospheric column for some weeks after the 7-10th January 


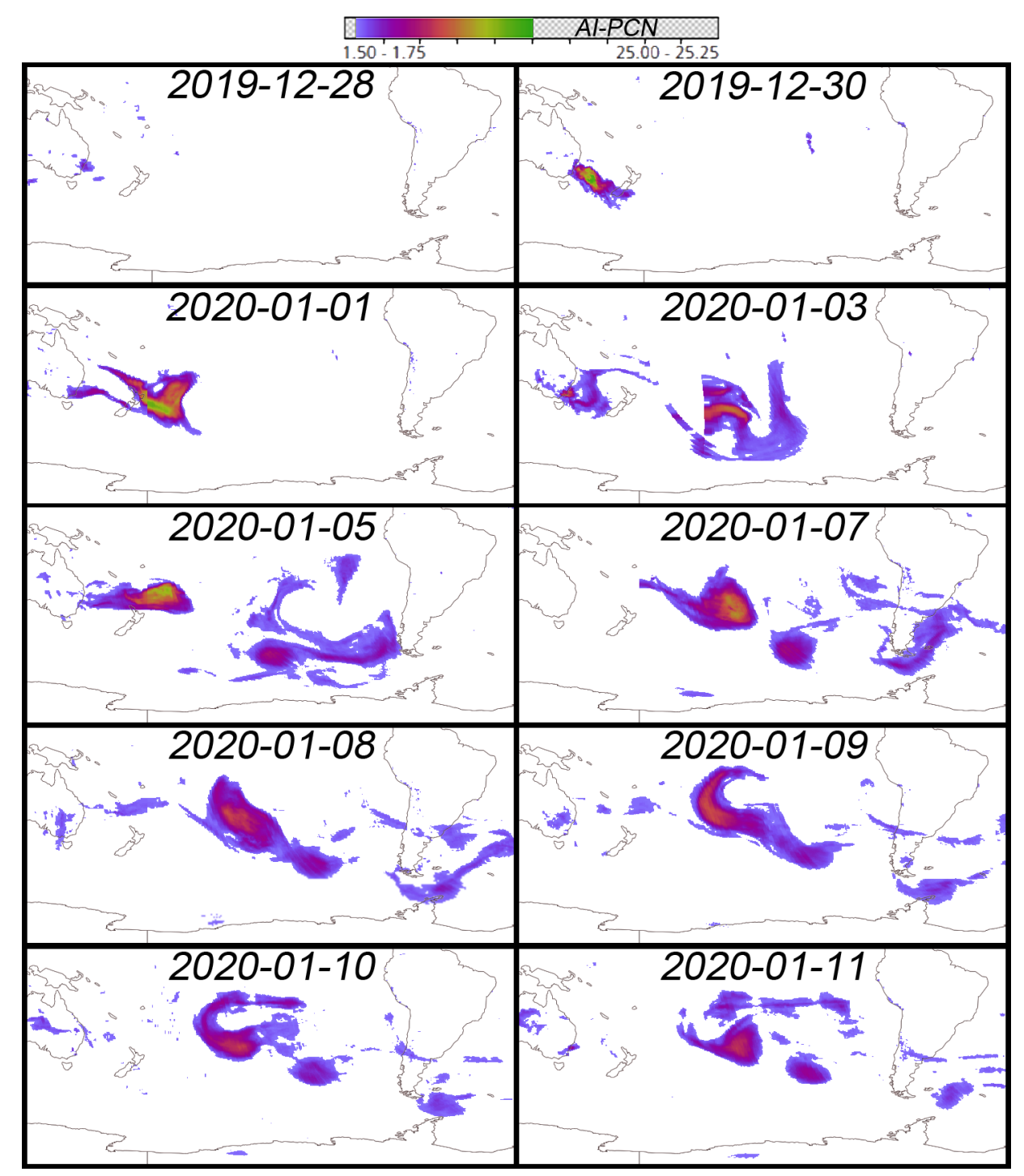

Figure 3.19: Aerosol Index PyroCumuloNimbus (AI-PCN) maps over Pacific ocean for 10 different days during the smoke transport from Australia to Marambio station. These maps have been extracted from NASA's Earth Observing System Data and Information System (EOSDIS) worldview tool (https://worldview.earthdata.nasa.gov) 


\section{RESULTADOS}

event. The analysis by Kablick III et al. (2020) also indicates that smoke could be present at Antarctic latitudes until mid-February. The AE, in the range 1.3 to 1.4 (also observed in Figure 3.16a), shows intermediate values which would indicate a certain contribution of coarse mode particles. However the fine/coarse mode separation of the AOD indicated that the coarse mode had a minor contribution to the AOD. The analysis of the particle size distribution is necessary to tackle this apparent contradiction.

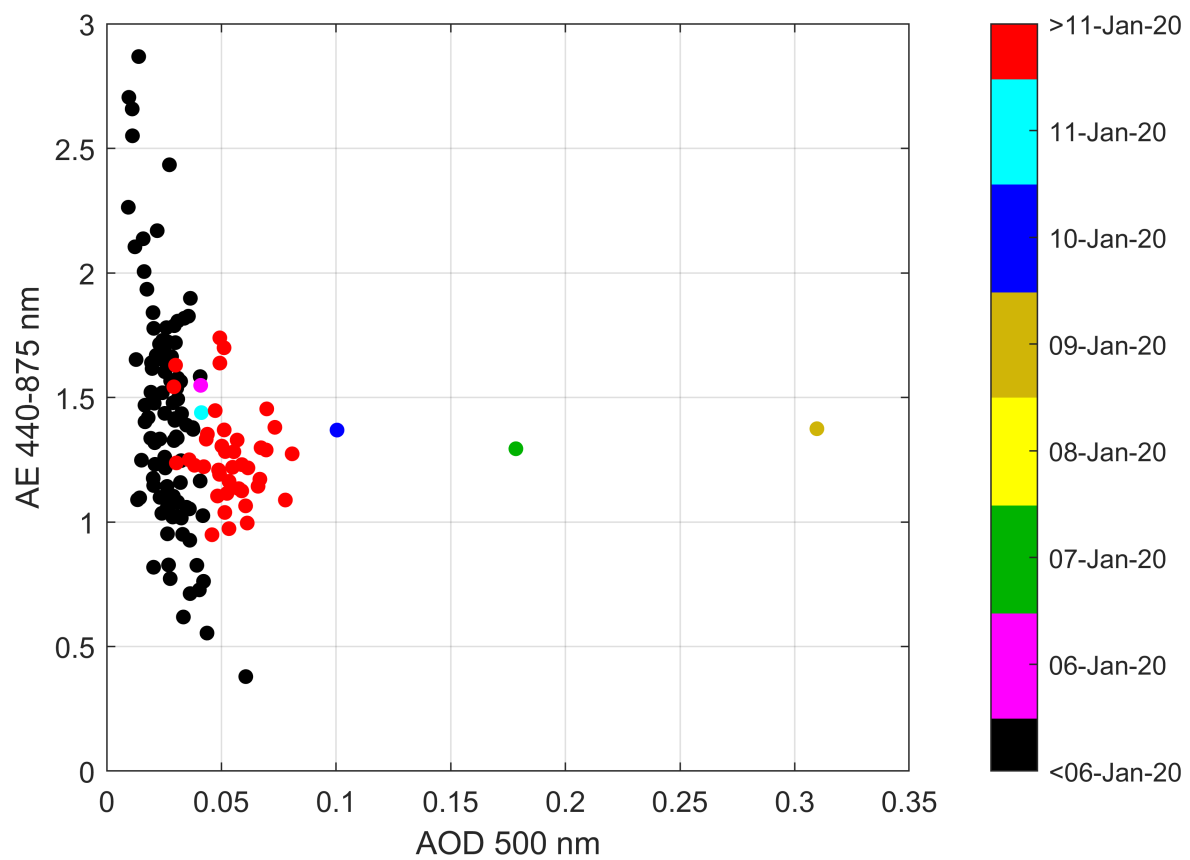

Figure 3.20: Daily mean of Ångström exponent (AE) vs. aerosol optical depth (AOD) at 500 $\mathrm{nm}$ at Marambio (until April 2020). Colorbar indicates the date of each data point highlighting the analyzed days of the event.

The favorable sky conditions during the event on 9th and 10th January (clouds are very frequent in this region), allowed sky radiance scans (almucantar and hybrid geometries) which could be inverted to retrieve the optical and microphysical properties of the aerosol. Given that the AOD during the event was much larger than the background values $(0.3$ on Jan. 9th vs. 0.025 on the 5th), we can assume that the inverted properties mainly correspond to those of the elevated smoke layer. We calculated the daily mean aerosol size distribution on the 9th and the 10th January, based on 6 and 9 inversions respectively. The result is shown in Figure 3.21, together with the average aerosol size distribution measured near the smoke plume origin, at the Tumbarumba site in Australia. The latter corresponds to the mean of the daily averages in the period 25-30th December 2019, during which high 
AOD was persistently measured due to active fires.

The size distribution at Tumbarumba was bimodal, with predominant fine mode. The average fine mode fraction was 0.64 in particle volume. However the coarse mode played a minor role in terms of AOD, with fine mode fraction of the AOD (500 nm) above 0.94 , as derived from the spectral deconvolution algorithm data. This minor role of the coarse mode was also noted in other studies about biomass burning Eck et al. (2001); Schafer et al. (2008). The lack of optically significant coarse mode is typical of biomass burning aerosols of several source regions Eck et al. (2009). The mean AOD (500 nm) derived here for the fresh biomass burning aerosol at Tumbarumba was 0.56 , indicating a significant aerosol load, that peaked on 1-3 January, with AOD (500 nm) above 5.0.

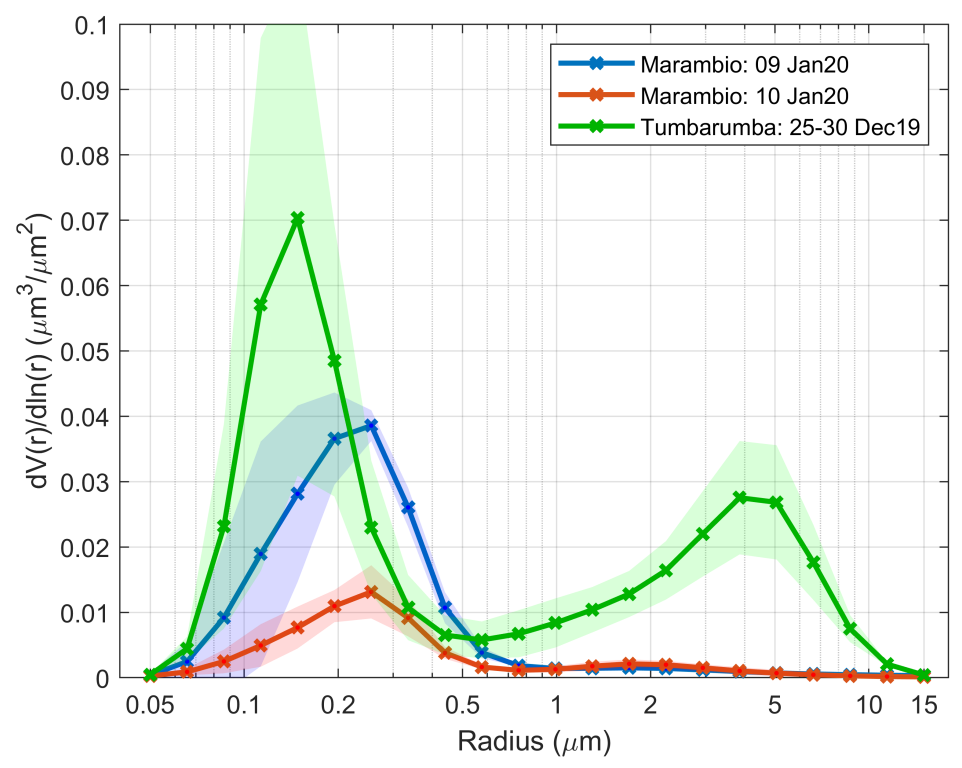

Figure 3.21: Volume particle size distribution over Marambio, Antarctica, on 9th and 10th January 2020 (daily averages), as well as the mean of the daily averaged size distribution over Tumbarumba, Australia, for the period 25-30 December 2019. Color shaded areas represent \pm 1 standard deviation.

Two main features arise from the comparison of the mean size distributions over Marambio and Tumbarumba. First, the coarse mode nearly disappeared in the lofted layer over Antarctica, suggesting that the large particles were most effectively scavenged during the long-range transport. Similar results have been observed in other aerosol events (e.g. Myhre et al., 2007). Second, the fine mode modal radius was larger at Marambio $(0.22 \mu \mathrm{m})$, than it was at Tumbarumba $(0.16 \mu \mathrm{m})$. These are average values for the mentioned periods (see Figure 3.21). An increase in the fine mode radius is typical for aged smoke, due to coagu- 


\section{RESULTADOS}

lation and condensation processes Ditas et al. (2018); Eck et al. (2009); Reid et al. (2005). This increase in the fine mode modal radius is likely the reason for the above-mentioned reduction in the $\mathrm{AE}$ to 1.34 at Marambio while the averaged daily $\mathrm{AE}$ at Tumbarumba was 1.82 for the 25-30 Dec. period. Radiative transfer simulations have been done using as input the AERONET averages of fine and coarse aerosol concentrations (at both sites), varying the fine mode modal radius; the obtained results (not shown) support the hypothesis that, for the observed aerosol fine and coarse concentrations, the AE decreases as the fine mode radius increases, in agreement with the measured data.

Differences on the aerosol optical properties obtained at Marambio and Tumbarumba have also been observed, possibly associated to ageing. The aerosol SSA and its wavelength dependence can be linked with the aerosol type Dubovik et al. (2002); Giles et al. (2012). At Tumbarumba, the SSA was about 0.96-0.97 at $440 \mathrm{~nm}$ and decreased in the longer wavelengths ( 0.93 at $1020 \mathrm{~nm}$ ), see Figure 3.22. These values are typical in biomass burning aerosols, e.g. in other fires reported in Australia Mitchell et al. (2006) and the Amazonian forest Dubovik et al. (2002). The SSA was much higher at Marambio, above 0.99 at all investigated wavelengths on 9th January, and a bit lower on 10th, and exhibiting very small spectral dependence on both days. The condensation and/or formation of secondary organic aerosol can result in enhanced values of SSA (Abel et al., 2003). The loss of coarse aerosols and the increase in relative humidity can be other possible factors that favor the increase of the SSA during transport Myhre et al. (2007).

The analysis of intensive optical properties can be used to discriminate aerosol types Giles et al. (2012). The approach consists of combining a size-related property (i.e. Ångström exponent, fine mode fraction of the AOD) with a parameter representing the absorptive properties (i.e. single scattering albedo or absorption Ångström exponent). Figure 3.23 a shows the absorption Ångström exponent (AAE) as function of the fine mode fraction of the AOD (500 nm) for Tumbarumba and Marambio, as provided by the AERONET inversion products. No significant change is observed in the AAE for both sites (1.21 at Tumbarumba, 1.19 at Marambio). They are within the expected range for biomass burning aerosols Giles et al. (2012). The highest FMF is found for the central day of the event at Marambio (10th January), where the data show very low scatter. Figure $3.23 \mathrm{~b}$ shows the AAE as a function of the AE of extinction. In this plot the separation of the data from both sites is clearer, given the decrease of the AE of the transported aerosol (1.34 at Marambio, 1.82 at Tumbarumba). In view of the aerosol key aerosol types described in Giles et al. (2012), the observed properties of the smoke over Marambio (intermediate values of the AE; very high FMF; and very high SSA), do not clearly match any of the described categories. The fact that the smoke 


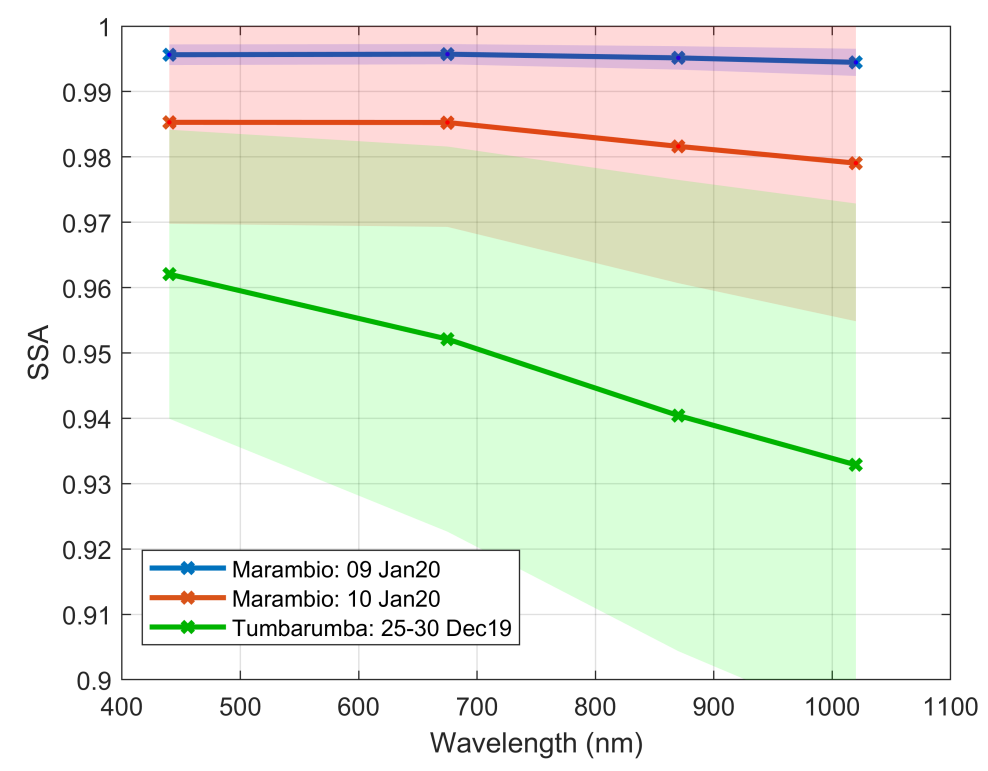

Figure 3.22: Single scattering albedo (SSA) as a function of wavelength over Marambio, Antarctica, on 9th and 10th January 2020 (daily averages), as well as the mean of the daily averaged SSA over Tumbarumba, Australia, for the period 25-30 December 2019. Color shaded areas represent \pm 1 standard deviation.

particles are found in the stratosphere and have experienced a long atmospheric transport, with associated ageing processes, can be the reason behind these distinct properties.

\subsubsection{Conclusions}

An extraordinary aerosol event with AOD at $500 \mathrm{~nm}$ above 0.3 was detected at Marambio station in the Antarctic Peninsula, by means of an AERONET Cimel CE318-T photometer. CALIPSO backscatter profiles, Suomi NPP aerosol index and back trajectory analysis, were analyzed to confirm the origin of the measured aerosol layer in the Australian fires that occurred about 10 days earlier, and injected large amounts of smoke particles up to the stratosphere. The particles were transported over the ocean and reached the Antarctic Peninsula at about $13 \mathrm{~km}$ height.

The fine mode particles largely dominated the aerosol size distribution, with the fine mode fraction of the AOD ranging from 0.94 to 0.99. The AOD levels during the event (710 January 2020) constitute the highest columnar values recorded in Marambio. The AOD data measured until April 2020 suggest that part of the smoke remained over Antarctica for several weeks after the analysed event. 

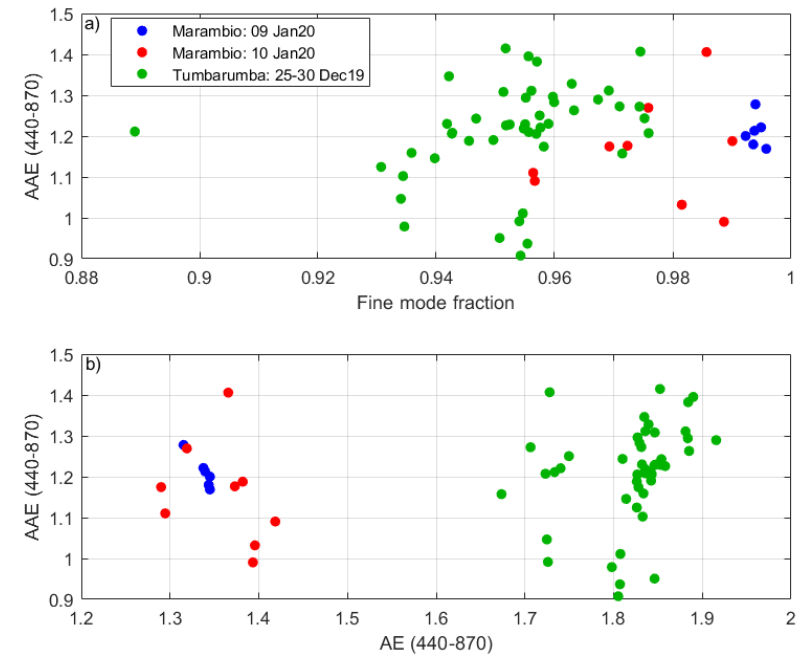

Figure 3.23: Absorption Ångström exponent (AAE) as a function of: (a) Fine Mode Fraction of the AOD (500 nm); and (b) Extinction Ångström exponent (AE) derived in the range 440-870 $\mathrm{nm}$. Data points are inversion data (almucantar and hybrid sky scans) for Marambio, Antarctica, on 9th and 10th January 2020, and Tumbarumba, Australia, for the period 25-30 December 2019.

The optical and microphysical aerosol properties of the fresh smoke aerosol were measured at the Australian AERONET site Tumbarumba. The comparison with Marambio data showed that the coarse mode particles were lost during the long-range transport, and that ageing processes increased the plume average aerosol particle size. In our case study, the fine mode modal radius increased from 0.16 to $0.22 \mu \mathrm{m}$. This increase in the fine mode radius could be the main responsible for the lower AE values at Marambio $(\sim 1.3)$ than at Tumbarumba $(\sim 1.8)$. The particles also became less absorbing, with single scattering albedo (440 nm) increasing from 0.96 to 0.99 (from 0.93 to 0.99 at $1020 \mathrm{~nm}$ ). Conversely, the absorption Ångström exponent did not change significantly (from 1.21 to 1.19).

The photometers used in AERONET have proven their capability to provide aerosol monitoring in Antarctica, including direct Sun irradiance measurements for AOD and well as sky radiance scans during daytime. Direct Moon irradiances are monitored since austral winter 2020 and will help to improve the year-round aerosol property monitoring. Longer data sets and the joint analysis of all the co-located aerosol measurements are still needed to provide consistent aerosol climatology in the region, investigate possible trends and identify the frequency and intensity of future events of long-range transported aerosols. 


\subsubsection{Acknowledgments}

The authors thank the Spanish Ministry of Science, Innovation and Universities for the support through the ePOLAAR project (RTI2018-097864-B-I00). The work was also supported by the Academy of Finland project Atmospheric Composition and Processes relevant to climate change in ANTarctica (ACPANT) [project number 264390]; the Centre on Excellence in Atmospheric Science funded by the Finnish Academy of Sciences Excellence [project number 307331]. We also received funding from the European Union's Horizon 2020 research and innovation programme [grant agreement number 654109]. The NOAA Air Resources Laboratory (ARL) is acknowledged for the provision of the HYSPLIT transport and dispersion model and READY website (https://www.ready.noaa.gov) used in this publication. NASA AERONET program and PI's are acknowledged for their effort in establishing and maintaining Tumbarumba and Marambio sites. The authors also thank NASA CALIPSO team for the data products used in this publication. These data were obtained from the NASA Langley Research Center Atmospheric Science Data Center. We are grateful for the logistic support received from the Finnish Antarctic Research Program (FINNARP) and from the Argentinean Air Force, which were highly valuable for the project. We warmly thank the technical personnel at Marambio for their support in logistics and measurements at the station.

\section{References}

See references section of the $\mathrm{PhD}$ Thesis. 



\section{Conclusiones y líneas futuras}

A lo largo de este trabajo se han desarrollado nuevos métodos que ayudan en las taréas de monitorización y análisis de los aerosoles atmosféricos. Estos métodos, que procesan el espesor óptico de aerosoles tanto para el día como para la noche, poseen un filtrado con el que se descarta cualquier medida contaminada por nubes. Con su puesta en producción en la herramienta CÆLLIS se aporta un mayor conocimiento sobre los aerosoles atmosféricos así como un control más exhaustivo sobre las medidas que se realizan por los equipos pertenicientes a la red AERONET.

Todo lo expuesto hasta hora se puede resumir en:

1. Se ha creado un algoritmo para el cálculo y procesado del espesor óptico de aerosoles (AOD) en CÆLIS. Este algoritmo calcula el AOD tanto para las medidas diurnas como para las nocturnas. El algortimo se ha descrito indicando en cada paso las acciones que se realizan y de dónde se obtiene la meta-información necesaria para los cálculos. Este algoritmo es aplicable a las diferentes familias de fotómetros que forman la red AERONET.

2. Relacionado con el cálculo del AOD nocturno, se ha definido el método de calibración que se utiliza en CÆLIS. Debido a la falta de exactitud presente en los modelos de irradiancia lunar, los cuales infraestiman la irradiancia lunar extraterrestre entre un 1 y un $14 \%$ dependiendo de la fase de la Luna y de la longitud de onda, se ha desarrollado un método de corrección (RCF) que permite obtener unos valores de AOD nocturnos mucho más realistas y que muestran buena continuidad con las medidas diurnas. Los 


\section{CONCLUSIONES Y LÍNEAS FUTURAS}

factores de corrección (RCF) se han modelado como un polinomio de segundo orden dependiente de la fase lunar para cada longitud de onda.

3. Para poder etiquetar los datos como libres o contaminados por nubes se ha desarrollado un algoritmo de eliminación de nubes (Cloud Screening) en CÆLIS. Este algoritmo, que sigue los criterios del utilizado en la red AERONET, ha quedado descrito indicándose las diferencias que puede tener en función de la familia de fotómetro a la que se esté aplicando así como las debidas al día y la noche.

4. Todos los algoritmos mencionados se han validado contra una base de datos independiente y de calidad contrastada. Por un lado el cálculo del AOD diurno como su Cloud Screening se han validado con los datos generados por la red AERONET. Para ello se han seleccionado 9 estaciones, que cumplen distintos requisitos, durante dos años, para tener un total de más de 250000 valores comparables. La diferencia de la comparación del AOD es inferior a 0.0015 para todas las longitudes de onda, lo cual es 1 orden de magnitud inferior a la incertidumbre del cálculo del AOD. La misma comparación se ha hecho para el Cloud Screening logrando un acuerdo entre las bases de datos de CÆLLIS y de AERONET en más de un $99.8 \%$ de los casos.

5. En cuanto al AOD nocturno, su validación se ha realizado con los datos obtenidos por un fotómetro estelar. En está comparación se han obtenido unas diferencias promedio menores a 0.01 para todas las longitudes de onda salvo $440 \mathrm{~nm}$, donde la diferencia es menor que 0.02. La validación del Cloud Screening nocturno se ha realizado de forma visual, al no disponer de otra base de datos independiente, y los resultados parecen satisfactorios. Tanto el AOD nocturno como el diurno muestran una continuidad en las horas de cambio de uno a otro para distintas latitudes y ángulos de fase de la Luna.

6. Una vez desarrollados y validados los distintos algoritmos se han puesto en producción en la herramienta CÆLIS con el objetivo de ofrecer información adicional sobre los aerosoles atmosféricos así como del estado de los fotómetros durante su funcionamiento. De esta forma se mejorará la información que se tiene de los aerosoles atmosféricos gracias a la mayor calidad de las medidas. Estos algoritmos ayudan además a la detección de episodios singulares.

7. Se ha detectado un evento anómalamente alto de aerosoles en la estación Antártica de Marambio, con valores de AOD superiores a 0.3 en $500 \mathrm{~nm}$. Este evento, observado entre los días 7 y 10 de enero de 2020, fue seguido a través de las medidas de un fotómetro CIMEL, así como de los perfiles de backscatter de CALIPSO, el aerosol index 
de Suomi NPP y las retrotrayectorias Hysplit, siendo su origen unos incendios acontecidos en el este de Australia en los últmos días de 2019, es decir, alrededor de 10 días anteriores a su detección. Conocidos los aerosoles en el origen y tras el transporte, se compararon las propiedades de uno y otro, observándose una perdida de las partículas más grandes, un incremento en el tamaño de las partículas más pequeñas, lo cual redujo el valor del exponente de Ånsgtröm. Además el aerosol, durante el transporte, se transformó en menos absorbente, aumentando el single scattering albedo.

Las principales conclusiones que se obtienen de este trabajo son:

- Se ha desarrollado y validado un algoritmo para el cálculo del AOD diurno y nocturno. Los resultados obtenidos en la validación ponen en manifiesto la capacidad que tiene CÆLIS de proporcionar este producto de manera operacional y robusta para una red de instrumentos fotométricos.

- Se ha desarrolaldo un método para corregir la infraestimación que el modelo RIMO hace de la irradiancia lunar extraterrestre mediante unos factores de corrección que dependen de la longitud de onda y de la fase lunar. Gracias a esta corrección, se ha reducido la incertidumbre del AOD nocturno, debida a la calibración, a niveles similares del AOD diurno.

- Se ha puesto en manifiesto la capacidad de los fotómetros de la red AERONET para monitorear de forma continua los aerosoles en la Antártida tanto en el día como en la noche polar. Gracias a la puesta en producción de los algoritmos de AOD desarrollados, ha sido posible detectar un evento de aerosol en la Antártida.

Este trabajo continúa una de las líneas de investigación seguida por el GOA-UVa y que pone en manifiesto el estudio de los aerosoles a través de técnicas avanzadas que permitan el tratamiento de grandes volúmenes de datos. Desde luego esta línea de investigación es amplia y no queda cerrada. De este trabajo se pueden deducir unas posibles líneas futuras de investigación que serán de gran ayuda cuando estén desarrolladas y validadas. Alguna de estas lineas son:

- Añadir más tipos de instrumentos al sistema, como pueden ser los fotómetros PFR o Prede y calcular el AOD utilizando los mismos pasos que los descritos para los fotómetros CIMEL. De esta forma el AOD obtenido por uno u otro instrumento podría ser comparable, aumentando la densidad de estaciones disponibles por todo el mundo. 
- Una de las carencias que tiene el algoritmo de filtrado de nubes es la ausencia en el análisis de una estación dónde predominen los grandes incendios forestales. Añadir una estación con estas caracteristicas ayudaría a detectar posibles errores en el Cloud Screening y buscar soluciones sin alterar los datos de AOD calculados.

- Comparar el algoritmo de Cloud Screening de la noche con alguna fuente de datos auxiliar o hacer una análisis mas minucioso de este algoritmo por la noche, que permita dilucidar si la adaptación que se hace con los datos de Sol es válida para los datos de Luna o si por el contrario hay que desarrollar un nuevo algoritmo adaptado a las necesidades de la noche. Para esto es de vital importancia ampliar el número de medidas realizadas durante la noche.

- Implantar en CÆLIS un algoritmo de inversión; actualmente se cuenta con una versión en pruebas del algoritmo GRASP en el sistema. Una validación de este algoritmo sería fundamental para disponer de todos los elementos de análisis de los aerosoles a partir de medidas fotométricas y no depender de fuentes externas. El algoritmo de inversión sería capaz de invertir los datos de AOD (GRASP-AOD). Esto mejoraría la caracterización de los aerosoles atmosféricos durante la noche, lo cual es crucial en las zonas polares. Así mismo, se trabajará en la inversión conjunta de AOD con medidas de radiancia en diferentes geometrías (almucantar, plano principal, híbrido) e incluso con otros instrumentos tales como ceilómetros o cámaras todo cielo. 


\section{Bibliografía}

Abel, S. J., Haywood, J. M., Highwood, E. J., Li, J., and Buseck, P. R. (2003). Evolution of biomass burning aerosol properties from an agricultural fire in southern africa. Geophysical Research Letters, 30(15). 98

Abreu, P., Aglietta, M., Ahlers, M., Ahn, E., Albuquerque, I., Allard, D., Allekotte, I., Allen, J., Allison, P., Almela, A., and et al. (2012). Description of atmospheric conditions at the pierre auger observatory using the global data assimilation system (gdas). Astroparticle Physics, 35(9), 591 - 607. 37

Acton, C., Bachman, N., Semenov, B., and Wright, E. (2018). A look towards the future in the handling of space science mission geometry. Planetary and Space Science, 150, 9-12. 42,65

Acton, C. H. (1996). Ancillary data services of nasa's navigation and ancillary information facility. Planetary and Space Science, 44(1), 65-70. 42, 65

Alados-Arboledas, L., Lyamani, H., and Olmo, F. (2003). Aerosol size properties at armilla, granada (spain). Quarterly Journal of the Royal Meteorological Society: A journal of the atmospheric sciences, applied meteorology and physical oceanography, 129(590), 13951413. 61

Albrecht, B. A. (1989). Aerosols, cloud microphysics, and fractional cloudiness. Science, 245(4923), 1227-1230. 4

Almansa, A. F., Cuevas, E., Torres, B., Barreto, A., García, R. D., Cachorro, V. E., de Frutos, A. M., López, C., and Ramos, R. (2017). A new zenith-looking narrow-band radiometerbased system (zen) for dust aerosol optical depth monitoring. Atmospheric Measurement Techniques, 10(2), 565-579. 17 


\section{BIBLIOGRAFÍA}

Almansa, A. F., Cuevas, E., Barreto, Á., Torres, B., García, O. E., Delia García, R., VelascoMerino, C., Cachorro, V. E., Berjón, A., Mallorquín, M., et al. (2020). Column integrated water vapor and aerosol load characterization with the new zen-r52 radiometer. Remote Sensing, 12(9), 1424. 17

Angström, A. (1961). Techniques of determining the turbidity of the atmosphere. Tellus, 13, 214-223. 8, 30, 59

Ansmann, A., Riebesell, M., and Weitkamp, C. (1990). Measurement of atmospheric aerosol extinction profiles with a raman lidar. Optics letters, 15(13), 746-748. 59

Antón, M., Valenzuela, A., Cazorla, A., Gil, J., Fernández-Gálvez, J., Lyamani, H., FoyoMoreno, I., Olmo, F., and Alados-Arboledas, L. (2012). Global and diffuse shortwave irradiance during a strong desert dust episode at granada (spain). Atmospheric research, 118, 232-239. 61

Asmi, E., Frey, A., Virkkula, A., Ehn, M., Manninen, H. E., Timonen, H., Tolonen-Kivimäki, O., Aurela, M., Hillamo, R., and Kulmala, M. (2010). Hygroscopicity and chemical composition of antarctic sub-micrometre aerosol particles and observations of new particle formation. Atmospheric Chemistry and Physics, 10(9), 4253-4271. 85

Asmi, E., Neitola, K., Teinilä, K., Rodriguez, E., Virkkula, A., Backman, J., Bloss, M., Jokela, J., Lihavainen, H., de Leeuw, G., Paatero, J., Aaltonen, V., Mei, M., Gambarte, G., Copes, G., Albertini, M., Fogwill, G. P., Ferrara, J., Barlasina, M. E., and Sánchez, R. (2018). Primary sources control the variability of aerosol optical properties in the antarctic peninsula. Tellus B: Chemical and Physical Meteorology, 70(1), 1-16. 85, 87, 88

Baars, H., Ansmann, A., Ohneiser, K., Haarig, M., Engelmann, R., Althausen, D., Hanssen, I., Gausa, M., Pietruczuk, A., Szkop, A., Stachlewska, I. S., Wang, D., Reichardt, J., Skupin, A., Mattis, I., Trickl, T., Vogelmann, H., Navas-Guzmán, F., Haefele, A., Acheson, K., Ruth, A. A., Tatarov, B., Müller, D., Hu, Q., Podvin, T., Goloub, P., Veselovskii, I., Pietras, C., Haeffelin, M., Fréville, P., Sicard, M., Comerón, A., Fernández García, A. J., Molero Menéndez, F., Córdoba-Jabonero, C., Guerrero-Rascado, J. L., Alados-Arboledas, L., Bortoli, D., Costa, M. J., Dionisi, D., Liberti, G. L., Wang, X., Sannino, A., Papagiannopoulos, N., Boselli, A., Mona, L., DÁmico, G., Romano, S., Perrone, M. R., Belegante, L., Nicolae, D., Grigorov, I., Gialitaki, A., Amiridis, V., Soupiona, O., Papayannis, A., Mamouri, R.-E., Nisantzi, A., Heese, B., Hofer, J., Schechner, Y. Y., Wandinger, U., and Pappalardo, G. (2019). The unprecedented 2017-2018 stratospheric smoke event: decay 
phase and aerosol properties observed with the earlinet. Atmospheric Chemistry and Physics, 19(23), 15183-15198. 85

Baibakov, K., O’Neill, N. T., Ivanescu, L., Duck, T. J., Perro, C., Herber, A., Schulz, K.-H., and Schrems, O. (2015). Synchronous polar winter starphotometry and lidar measurements at a high arctic station. Atmospheric Measurement Techniques, 8(9), 3789-3809. 59,63

Barreto, A., Cuevas, E., Damiri, B., Guirado, C., Berkoff, T., Berjón, A. J., Hernández, Y., Almansa, F., and Gil, M. (2013). A new method for nocturnal aerosol measurements with a lunar photometer prototype. Atmospheric Measurement Techniques, 6(3), 585-598. 42. 49, 59, 64, 66

Barreto, A., Cuevas, E., Granados-Muñoz, M.-J., Alados-Arboledas, L., Romero, P. M., Gröbner, J., Kouremeti, N., Almansa, A. F., Stone, T., Toledano, C., Román, R., Sorokin, M., Holben, B., Canini, M., and Yela, M. (2016). The new sun-sky-lunar cimel ce318-t multiband photometer - a comprehensive performance evaluation. Atmospheric Measurement Techniques, 9(2), 631-654. 43, 60, 66, 69, 88

Barreto, Á., Román, R., Cuevas Agulló, E., Berjón, A., Almansa Rodríguez, A. F., Toledano, C., González, R., Pérez, H., Yballa, C., Blarel, L., et al. (2017). Assessment of nocturnal aerosol optical depth from lunar photometry at the izaña high mountain observatory. Atmospheric Measurement Techniques, 10(8), 3007-3019. 49, 60, 66, 67, 68

Barreto, A., Román, R., Cuevas, E., Pérez-Ramírez, D., Berjón, A. J., Kouremeti, N., Kazadzis, S., Gröbner, J., Mazzola, M., Toledano, C., et al. (2019). Evaluation of night-time aerosols measurements and lunar irradiance models in the frame of the first multi-instrument nocturnal intercomparison campaign. Atmospheric Environment, 202, 190-211. 9. $42,49$. 59, 60, 63, 64, 65, 74,

Basart, S., Pérez, C., Cuevas, E., Baldasano, J. M., and Gobbi, G. P. (2009). Aerosol characterization in Northern Africa, Northeastern Atlantic, Mediterranean Basin and Middle East from direct-sun AERONET observations. Atmospheric Chemistry and Physics, 9, 8265-8282. 61

Bedoya-Velásquez, A. E., Navas-Guzmán, F., Granados-Muñoz, M. J., Titos, G., Román, R., Casquero-Vera, J. A., Ortiz-Amezcua, P., Benavent-Oltra, J. A., de Arruda Moreira, G., Montilla-Rosero, E., Hoyos, C. D., Artiñano, B., Coz, E., Olmo-Reyes, F. J., AladosArboledas, L., and Guerrero-Rascado, J. L. (2018). Hygroscopic growth study in the 


\section{BIBLIOGRAFÍA}

framework of earlinet during the slope i campaign: synergy of remote sensing and in situ instrumentation. Atmospheric Chemistry and Physics, 18(10), 7001-7017. 63

Benavent-Oltra, J. A., Román, R., Granados-Muñoz, M. J., Pérez-Ramírez, D., OrtizAmezcua, P., Denjean, C., Lopatin, A., Lyamani, H., Torres, B., Guerrero-Rascado, J. L., Fuertes, D., Dubovik, O., Chaikovsky, A., Olmo, F. J., Mallet, M., and Alados-Arboledas, L. (2017). Comparative assessment of grasp algorithm for a dust event over granada (spain) during charmex-adrimed 2013 campaign. Atmospheric Measurement Techniques, 10(11), 4439-4457. 6, 61

Benavent-Oltra, J. A., Román, R., Casquero-Vera, J. A., Pérez-Ramírez, D., Lyamani, H., Ortiz-Amezcua, P., Bedoya-Velásquez, A. E., de Arruda Moreira, G., Barreto, A., Lopatin, A., Fuertes, D., Herrera, M., Torres, B., Dubovik, O., Guerrero-Rascado, J. L., Goloub, P., Olmo-Reyes, F. J., and Alados-Arboledas, L. (2019). Different strategies to retrieve aerosol properties at night-time with the grasp algorithm. Atmospheric Chemistry and Physics, 19(22), 14149-14171. 59, 73

Bennouna, Y., Cachorro, V., Toledano, C., Berjón, A., Prats, N., Fuertes, D., Gonzalez, R., Rodrigo, R., Torres, B., and de Frutos, A. (2011). Comparison of atmospheric aerosol climatologies over southwestern Spain derived from AERONET and MODIS. Remote Sensing of Environement, 115, 1272-1284. 16

Bennouna, Y., Torres, B., Cachorro, V., Ortiz de Galisteo, J., and Toledano, C. (2013). The evaluation of the integrated water vapour annual cycle over the iberian peninsula from eos-modis against different ground-based techniques. Quarterly Journal of the Royal Meteorological Society, 139(676), 1935-1956. 16

Berkoff, T. A., Sorokin, M., Stone, T., Eck, T. F., Hoff, R., Welton, E., and Holben, B. (2011). Nocturnal Aerosol Optical Depth Measurements with a Small-Aperture Automated Photometer Using the Moon as a Light Source. Journal of Atmospheric and Oceanic Technology, 28(10), 1297-1306. 49,59

Bodhaine, B. A., Wood, N. B., Dutton, E. G., and Slusser, J. R. (1999). On rayleigh optical depth calculations. Journal of Atmospheric and Oceanic Technology, 16(11), 1854-1861. 41

Boer, M., Resco de Dios, V., and Bradstock, R. (2020). Unprecedented burn area of australian mega forest fires. Nat. Clim. Chang., 9, 171-172. 85 
Boucher, O., Randall, D., Artaxo, P., Bretherton, C., Feingold, G., Forster, P., Kerminen, V.M., Kondo, Y., Liao, H., Lohmann, U., Rasch, P., Satheesh, S., Sherwood, S., Stevens, B., and Zhang, X. (2013a). Clouds and Aerosols, book section 7, page 571-658. Cambridge University Press, Cambridge, United Kingdom and New York, NY, USA. 2, 3

Boucher, O., Randall, D., Artaxo, P., Bretherton, C., Feingold, G., Forster, P., Kerminen, V.M., Kondo, Y., Liao, H., Lohmann, U., et al. (2013b). Clouds and aerosols. In Climate change 2013: the physical science basis. Contribution of Working Group I to the Fifth Assessment Report of the Intergovernmental Panel on Climate Change, pages 571-657. Cambridge University Press. 58, 59

Bureau of Meteorology, . (2019). Special climate statement 72-dangerous bushfire weather in spring 2019. Technical report, Australian Bureau of Meteorology. 86

Cachorro, V., de Frutos, A. M., and Casanova, J. (1985). Comparison between various models of solar spectral irradiance and experimental data. Applied optics, 24(19), 3249-3253. 16

Cachorro, V., Vergaz, R., and de Frutos, A. M. (2001). A quantitative comparison of alpha$\tilde{\mathrm{A}}^{-} \hat{\mathrm{A}}_{i} \hat{\mathrm{A}} \frac{1}{2}$ turbidity parameter retrieved in different spectral ranges based on spectroradiometer solar radiation measurements. Atmospheric Environment, 3, special issue, 51175124. 16

Cachorro, V. E., de Frutos, A. M., and Casanova, J. L. (1987). Determination of the angstrom turbidity parameters. Appl. Opt., 26(15), 3069-3076. 7, 16, 40

Cachorro, V. E., Romero, P. M., Toledano, C., Cuevas, E., and de Frutos, A. M. (2004). The fictitious diurnal cycle of aerosol optical depth: A new approach for ïn situ" calibration and correction of AOD data series. Geophysical Research Letters, 31, L12106. 68

Cachorro, V. E., Toledano, C., Berjon, A., de Frutos, A. M., Torres, B., Sorribas, M., and Laulainen, N. S. (2008). An "in situ" calibration-correction procedure (KCICLO) based on AOD diurnal cycle: Application to AERONET - El Arenosillo (Spain) AOD data series. Journal of Geophysical Research, 113, D12205. 50, 68, 75

Cachorro, V. E., Toledano, C., Anton, M., Berjon, A., de Frutos, A., Vilaplana, J. M., Arola, A., and Krotkov, N. A. (2010). Comparison of UV irradiances from Aura/Ozone Monitoring Instrument (OMI) with Brewer measurements at El Arenosillo (Spain) - Part 2: Analysis of site aerosol influence. Atmos. Chem. Phys., 10(23), 11867-11880. 16 


\section{BIBLIOGRAFÍA}

Casquero-Vera, J. A., Lyamani, H., Titos, G., Borrás, E., Olmo, F., and Alados-Arboledas, L. (2019). Impact of primary no2 emissions at different urban sites exceeding the european no2 standard limit. Science of The Total Environment, 646, 1117-1125. 62

Casquero-Vera, J. A., Lyamani, H., Dada, L., Hakala, S., Paasonen, P., Román, R., Fraile, R., Petäjä, T., Olmo-Reyes, F. J., and Alados-Arboledas, L. (2020). New particle formation at urban and high-altitude remote sites in the south-eastern iberian peninsula. Atmospheric Chemistry and Physics Discussions, 2020, 1-32. 63

Cazorla, A., Casquero-Vera, J. A., Román, R., Guerrero-Rascado, J. L., Toledano, C., Cachorro, V. E., Orza, J. A. G., Cancillo, M. L., Serrano, A., Titos, G., Pandolfi, M., Alastuey, A., Hanrieder, N., and Alados-Arboledas, L. (2017). Near-real-time processing of a ceilometer network assisted with sun-photometer data: monitoring a dust outbreak over the iberian peninsula. Atmospheric Chemistry and Physics, 17(19), 11861-11876. 17

Cuevas, E., Milford, C., Bustos, J. J., del Campo-Hernández, R., García, O. E., García, R. D., Gómez-Peláez, A. J., Guirado-Fuentes, C., Marrero, C., Prats, N., Ramos, R., Redondas, A., Reyes, E., Rodríguez, S., Romero-Campos, P. M., Schneider, M., Belmonte, J., Yela, M., Almansa, F., Barreto, A., López-Solano, C., Basart, S., Terradellas, E., Afonso, S., Bayo, C., Berjón, A., Bethencourt, J., Carreño, V., Castro, N. J., Cruz, A. M., Damas, M., De Ory-Ajamil, F., García, M., Gómez-Trueba, V., González, Y., Hernández, C., Hernández, Y., Hernández-Cruz, B., Jover, M., León-Luís, S. F., López-Fernández, R., López-Solano, J., Rodríguez, E., Rodríguez-Franco, J. J., Rodríguez-Valido, M., Sálamo, C., Sanromá, E., Santana, D., Santo Tomás, F., Sepúlveda, E., Sierra, M., and Sosa, E. (2017). Izaña atmospheric research center activity report 2015-2016. Technical report, State Meteorological Agency of Spain (AEMET), Madrid, Spain and World Meteorological Organization, Geneva, Switzerland. (Eds.) Cuevas, E., Milford, C. and Tarasova, O. NIPO: 014-17-012-9, WMO/GAW Report No. 236. 61

Cuevas, E., Romero-Campos, P. M., Kouremeti, N., Kazadzis, S., Räisänen, P., García, R. D., Barreto, A., Guirado-Fuentes, C., Ramos, R., Toledano, C., Almansa, F., and Gröbner, J. (2019). Aerosol optical depth comparison between gaw-pfr and aeronet-cimel radiometers from long-term (2005-2015) 1 min synchronous measurements. Atmospheric Measurement Techniques, 12(8), 4309-4337. 47, 60, 61

Davidson, C. I., Phalen, R. F., and Solomon, P. A. (2005). Airborne particulate matter and human health: a review. Aerosol Science and Technology, 39(8), 737-749. 58 
de Arruda Moreira, G., Guerrero-Rascado, J. L., Bravo-Aranda, J. A., Benavent-Oltra, J. A., Ortiz-Amezcua, P., Róman, R., Bedoya-Velásquez, A. E., Landulfo, E., and AladosArboledas, L. (2018). Study of the planetary boundary layer by microwave radiometer, elastic lidar and doppler lidar estimations in southern iberian peninsula. Atmospheric Research, 213, 185-195. 63

Ditas, J., Ma, N., Zhang, Y., Assmann, D., Neumaier, M., Riede, H., Karu, E., Williams, J., Scharffe, D., Wang, Q., Saturno, J., Schwarz, J. P., Katich, J. M., McMeeking, G. R., Zahn, A., Hermann, M., Brenninkmeijer, C. A. M., Andreae, M. O., Pöschl, U., Su, H., and Cheng, Y. (2018). Strong impact of wildfires on the abundance and aging of black carbon in the lowermost stratosphere. Proceedings of the National Academy of Sciences, 115(50), E11595-E11603. 98

Dowdy, A. J., Ye, H., Pepler, A., Thatcher, M., Osbrough, S. L., Evans, J. P., Di Virgilio, G., and McCarthy, N. (2019). Future changes in extreme weather and pyroconvection risk factors for australian wildfires. Scientific Reports, 10, 10073. 85

Dubovik, O. and King, M. D. (2000). A flexible inversion algorithm for retrieval of aerosol optical properties from sun and sky radiance measurements. Journal of Geophysical Research: Atmospheres, 105(D16), 20673-20696. 9, 21, 88, 89

Dubovik, O., Holben, B., Eck, T. F., Smirnov, A., Kaufman, Y. J., King, M. D., Tanré, D., and Slutsker, I. (2002). Variability of absorption and optical properties of key aerosol types observed in worldwide locations. Journal of the atmospheric sciences, 59(3), 590-608. 10, 98

Dubovik, O., Sinyuk, A., Lapyonok, T., Holben, B. N., Mishchenko, M., Yang, P., Eck, T. F., Volten, H., Muñoz, O., Veihelmann, B., van der Zande, W. J., Léon, J.-F., Sorokin, M., and Slutsker, I. (2006). Application of spheroid models to account for aerosol particle nonsphericity in remote sensing of desert dust. Journal of Geophysical Research, 111, D11208. 9

Dubovik, O., Lapyonok, T., Litvinov, P., Herman, M., Fuertes, D., Ducos, F., Lopatin, A., Chaikovsky, A., Torres, B., Derimian, Y., et al. (2014). Grasp: a versatile algorithm for characterizing the atmosphere. SPIE Newsroom, 25. 9, 21, 53

D’Almeida, G., Koepke, P., and Shettle, E. P. (1991). Atmospheric Aerosol: Global Climatology and Radiative Characteristics. A Deepak Publishing Hampton, VA (USA). 2 


\section{BIBLIOGRAFÍA}

Eck, T. F., Holben, B. N., Reid, J. S., Dubovik, O., Smirnov, A., O’Neill, N. T., Slutsker, I., and Kinne, S. (1999). The wavelength dependence of the optical depth of biomass burning, urban and desert dust aerosols. J. Geophys. Res., 104, 31333-31350. 41

Eck, T. F., Holben, B. N., Ward, D. E., Dubovik, O., Reid, J. S., Smirnov, A., Mukelabai, M. M., Hsu, N. C., OÑeill, N. T., and Slutsker, I. (2001). Characterization of the optical properties of biomass burning aerosols in zambia during the 1997 zibbee field campaign. Journal of Geophysical Research: Atmospheres, 106(D4), 3425-3448. 97

Eck, T. F., Holben, B. N., Reid, J. S., OÑeill, N. T., Schafer, J. S., Dubovik, O., Smirnov, A., Yamasoe, M. A., and Artaxo, P. (2003). High aerosol optical depth biomass burning events: A comparison of optical properties for different source regions. Geophysical Research Letters, 30(20). 85

Eck, T. F., Holben, B. N., Reid, J. S., Sinyuk, A., Hyer, E. J., OÑeill, N. T., Shaw, G. E., Vande Castle, J. R., Chapin, F. S., Dubovik, O., Smirnov, A., Vermote, E., Schafer, J. S., Giles, D., Slutsker, I., Sorokine, M., and Newcomb, W. W. (2009). Optical properties of boreal region biomass burning aerosols in central alaska and seasonal variation of aerosol optical depth at an arctic coastal site. Journal of Geophysical Research: Atmospheres, 114(D11). 97, 98

Fiebig, M., Lunder, C. R., and Stohl, A. (2009). Tracing biomass burning aerosol from south america to troll research station, antarctica. Geophysical Research Letters, 36(14). 85

Flentje, H., Claude, H., Elste, T., Gilge, S., Köhler, U., Plass-Dülmer, C., Steinbrecht, W., Thomas, W., Werner, A., and Fricke, W. (2010). The Eyjafjallajökull eruption in April 2010 - detection of volcanic plume using in-situ measurements, ozone sondes and lidarceilometer profiles. Atmos. Chem. Phys., 10, 10085-10092. 58

Flynn, L., Long, C., Wu, X., Evans, R., Beck, C. T., Petropavlovskikh, I., McConville, G., Yu, W., Zhang, Z., Niu, J., Beach, E., Hao, Y., Pan, C., Sen, B., Novicki, M., Zhou, S., and Seftor, C. (2014). Performance of the ozone mapping and profiler suite (omps) products. Journal of Geophysical Research: Atmospheres, 119(10), 6181-6195. 89

Folkner, W. M., Williams, J. G., and Boggs, D. H. (2008). The planetary and lunar ephemeris de 421. JPL IOM 343R-08-003. 66

Fuertes, D. (2018). Desarrollo de nuevos métodos y herramientas para la caracterización avanzada de aerosoles atmosféricos a partir de medidas de teledetección. Ph.D. thesis, Universidad de Valladolid. 22 
Fuertes, D., Toledano, C., González, R., Berjón, A., Torres, B., Cachorro, V. E., and de Frutos, A. M. (2018). Cælis: software for assimilation, management and processing data of an atmospheric measurement network. Geoscientific Instrumentation, Methods and Data Systems, 7(1), 67-81. 16, 23, 31, 34, 36, 63, 88, 130

García, O. E., Díaz, J. P., Expósito, F. J., Díaz, A. M., Dubovik, O., Derimian, Y., Dubuisson, P., and Roger, J.-C. (2012). Shortwave radiative forcing and efficiency of key aerosol types using aeronet data. Atmospheric Chemistry and Physics, 12(11), 5129-5145. 61

García, R., García, O., Cuevas, E., Cachorro, V., Romero-Campos, P., Ramos, R., and de Frutos, A. (2014). Solar radiation measurements compared to simulations at the bsrn izaña station. mineral dust radiative forcing and efficiency study. Journal of Geophysical Research: Atmospheres, 119(1), 179-194. 17

Geogdzhayev, I. V. and Marshak, A. (2018). Calibration of the dscovr epic visible and nir channels using modis terra and aqua data and epic lunar observations. Atmospheric Measurement Techniques, 11(1), 359-368. 60, 69

Giles, D. M., Holben, B. N., Eck, T. F., Sinyuk, A., Smirnov, A., Slutsker, I., Dickerson, R. R., Thompson, A. M., and Schafer, J. S. (2012). An analysis of aeronet aerosol absorption properties and classifications representative of aerosol source regions. Journal of Geophysical Research: Atmospheres, 117(D17). 98

Giles, D. M., Sinyuk, A., Sorokin, M. G., Schafer, J. S., Smirnov, A., Slutsker, I., Eck, T. F., Holben, B. N., Lewis, J. R., Campbell, J. R., Welton, E. J., Korkin, S. V., and Lyapustin, A. I. (2019). Advancements in the aerosol robotic network (aeronet) version 3 database - automated near-real-time quality control algorithm with improved cloud screening for sun photometer aerosol optical depth (aod) measurements. Atmospheric Measurement Techniques, 12(1), 169-209. 31, 37, 38, 41, 43, 44, 45, 46, 50, 52, 62, 64, 73, 88, 89

Giordano, M. R., Kalnajs, L. E., Avery, A., Goetz, J. D., Davis, S. M., and DeCarlo, P. F. (2017). A missing source of aerosols in antarctica - beyond long-range transport, phytoplankton, and photochemistry. Atmospheric Chemistry and Physics, 17(1), 1-20. 85

González, R., Toledano, C., Román, R., Mateos, D., Asmi, E., Rodríguez, E., Lau, I. C., Ferrara, J., D’Elia, R., Antuña-Sánchez, J. C., Cachorro, V. E., Calle, A., and de Frutos, A. M. (2020a). Characterization of stratospheric smoke particles over the antarctica by remote sensing instruments. Remote Sensing, acepted, 12(22, 3769). 12 


\section{BIBLIOGRAFÍA}

González, R., Toledano, C., Román, R., Fuertes, D., Berjón, A., Mateos, D., GuiradoFuentes, C., Velasco-Merino, C., Antuña Sánchez, J. C., Calle, A., Cachorro, V. E., and de Frutos, A. M. (2020b). Daytime and nighttime aerosol optical depth implementation in cælis. Geoscientific Instrumentation, Methods and Data Systems, 9(2), 417-433. 12, 63, 64, 72, 73, 88

Graß 1, S. and Ritter, C. (2019). Properties of arctic aerosol based on sun photometer longterm measurements in ny-Ålesund, svalbard. Remote Sensing, 11(11), 1362. 85

Graß1, S. and Ritter, C. (2019). Properties of arctic aerosol based on sun photometer longterm measurements in ny-ålesund, svalbard. Remote Sensing, 11(11), 1362. 59

Gueymard, C. (1998). Turbidity determination from broadband irradiance measurements: A detailed multicoefficient approach. Journal of Applied Meteorology, 37, 414-435. 39

Guirado, C., Cuevas, E., Cachorro, V., Toledano, C., Alonso-Pérez, S., Bustos, J., Basart, S., Romero, P., Camino, C., Mimouni, M., et al. (2014). Aerosol characterization at the saharan aeronet site tamanrasset. Atmospheric Chemistry and Physics, 14(21), 1175311773. 68

Guirado-Fuentes, C. (2015). Caracterización de las propiedades de los aerosoles en columna en la región subtropical. Ph.D. thesis, Universidad de Valladolid. 19, 61, 129

Harrison, L., Michalsky, J., and Berndt, J. (1994). Automated multifilter rotating shadowband radiometer: an instrument for optical depth and radiation measurements. Appl. Opt., 33(22), 5118-5125. 43

Herber, A., Thomason, L. W., Gernandt, H., Leiterer, U., Nagel, D., Schulz, K., Kaptur, J., Albrecht, T., and Notholt, J. (2002). Continuous day and night aerosol optical depth observations in the Arctic between 1991 and 1999. J. Geophys. Res., 107(NO. D10), 4097. 59

Herreras, M., Román, R., Cazorla, A., Toledano, C., Lyamani, H., Torres, B., Cachorro, V., Olmo, F., Alados-Arboledas, L., and de Frutos, A. (2019). Evaluation of retrieved aerosol extinction profiles using as reference the aerosol optical depth differences between various heights. Atmospheric Research, 230, 104625. 17

Hofmann, D. (1988). Aerosols from past and present volcanic emissions. Aerosols and Climate, pages 195-214. 2 
Holben, B., Tanre, D., Smirnov, A., Eck, T., Slutsker, I., Abuhassan, N., Newcomb, W., Schafer, J., Chatenet, B., Lavenue, F., Kaufman, Y., Vande Castle, J., Setzer, A., Markham, B., Clark, D., Frouin, R., Halthore, R., Karnieli, A., OÑeill, N., Pietras, C., Pinker, R., Voss, K., and Zibordi, G. (2001). An emerging ground-based aerosol climatology: Aerosol Optical Depth from AERONET. J. Geophys. Res., 106, 12067-12097. 94

Holben, B. N., Eck, T. F., Slutsker, I., Tanré, D., Buis, J. P., Setzer, A., Vermote, E., Reagan, J. A., Kaufman, Y. J., Nakajima, T., Lavenu, F., Jankowiak, I., and Smirnov, A. (1998). AERONET - a federated instrument network and data archive for aerosol characterization. Remote Sens. Environ., 66, 1-16. 14, 30, 41, 50, 59, 62, 64, 86, 88

IPCC (2014). Climate change 2014: Synthesis report. contribution of working groups i, ii and iii to the fifth assessment report of the intergovernmental panel on climate change )]. ipcc,. Technical report, Intergovernmental Panel on Climate Change, Geneva, Switzerland. 151 pp. 29, 58,85

Jickells, T., An, Z., Andersen, K. K., Baker, A., Bergametti, G., Brooks, N., Cao, J., Boyd, P., Duce, R., Hunter, K., et al. (2005). Global iron connections between desert dust, ocean biogeochemistry, and climate. science, 308(5718), 67-71. 58

Kablick III, G. P., Allen, D. R., Fromm, M. D., and Nedoluha, G. E. (2020). Australian pyrocb smoke generates synoptic-scale stratospheric anticyclones. Geophysical Research Letters, 47(13), e2020GL088101. 86, 91,94,96

Kasten, F. (1965). A new table and approximation formula for the relative optial air mass. Arch. Met. Geoph. Biokl. B., 14, 206-223. 41

Kasten, F. and Young, A. T. (1989). Revised Optical Air Mass Tables and Approximation Formula. Appl. Opt., 28, 4735-4738. 7, 41, 43

Kazadzis, S., Kouremeti, N., Diémoz, H., Gröbner, J., Forgan, B. W., Campanelli, M., Estellés, V., Lantz, K., Michalsky, J., Carlund, T., Cuevas, E., Toledano, C., Becker, R., Nyeki, S., Kosmopoulos, P. G., Tatsiankou, V., Vuilleumier, L., Denn, F. M., Ohkawara, N., Ijima, O., Goloub, P., Raptis, P. I., Milner, M., Behrens, K., Barreto, A., Martucci, G., Hall, E., Wendell, J., Fabbri, B. E., and Wehrli, C. (2018a). Results from the fourth wmo filter radiometer comparison for aerosol optical depth measurements. Atmospheric Chemistry and Physics, 18(5), 3185-3201. 13 


\section{BIBLIOGRAFÍA}

Kazadzis, S., Kouremeti, N., Nyeki, S., Gröbner, J., and Wehrli, C. (2018b). The world optical depth research and calibration center (worcc) quality assurance and quality control of gaw-pfr aod measurements. Geoscientific Instrumentation, Methods and Data Systems, 7(1), 39-53. 30

Khatri, P. and Takamura, T. (2009). An algorithm to screen cloud-affected data for sky radiometer data analysis. Journal of the Meteorological Society of Japan. Ser. II, 87(1), 189-204. 43

Khaykin, S., Legras, B., Bucci, S., Sellitto, P., Isaksen, L., Tencé, F., Bekki, S., Bourassa, A., Rieger, L., Zawada, D., Jumelet, J., and Godin-Beekmann, S. (2020). The 2019/20 australian wildfires generated a persistent smoke-charged vortex rising up to $35 \mathrm{~km}$ altitude. Communications Earth \& Environment, 1(22). 86, 94

Kieffer, H. H. and Stone, T. C. (2005). The spectral irradiance of the moon. The Astronomical Journal, 129(6), 2887-2901. 9, 42, 49, 60, 64, 65, 69

Komhyr, W. D., Grass, R. D., and Leonard, R. K. (1989). Dobson spectrophotometer 83: A standard for total ozone measurements, 1962-1987. Journal of Geophysical Research: Atmospheres, 94(D7), 9847-9861. 41.

Koren, I., Kaufman, Y. J., Washington, R., Todd, M. C., Rudich, Y., Martins, J. V., and Rosenfeld, D. (2006). The bodéle depression: a single spot in the sahara that provides most of the mineral dust to the amazon forest. Environmental Research Letters, 1(1), 014005. 58

Krotkov, N. A., Lamsal, L. N., Celarier, E. A., Swartz, W. H., Marchenko, S. V., Bucsela, E. J., Chan, K. L., Wenig, M., and Zara, M. (2017). The version $3 \mathrm{omi} \mathrm{no}_{2}$ standard product. Atmospheric Measurement Techniques, 10(9), 3133-3149. 38

Kuhn, M. (1972). Global pollution in antarctic air documented by solar radiation depletion. Antarct. J. U.S., 7, 35-37. 85

Lacherade, S., Viticchié, B., Stone, T., Lebégue, L., Wagner, S., and Hewison, T. (2013). On the phase-angle dependence of the moon calibration results. GSICS Quat: Lunar calibration, 7(3). 9

Lacherade, S., Aznay, O., Fougnie, B., and Lebègue, L. (2014). Polo: a unique dataset to derive the phase angle dependence of the moon irradiance. In Sensors, Systems, and NextGeneration Satellites XVIII, volume 9241, page 924112. International Society for Optics and Photonics. 60, 68, 69 
Li, Z., Li, K., Li, D., Yang, J., Xu, H., Goloub, P., and Victori, S. (2016). Simple transfer calibration method for a cimel sun-moon photometer: calculating lunar calibration coefficients from sun calibration constants. Applied optics, 55(27), 7624-7630. 60, 66

Liu, B., Ma, Y., Shi, Y., Jin, S., Jin, Y., and Gong, W. (2020). The characteristics and sources of the aerosols within the nocturnal residual layer over wuhan, china. Atmospheric Research, page 104959. 59

Lopatin, A., Dubovik, O., Chaikovsky, A., Goloub, P., Lapyonok, T., Tanré, D., and Litvinov, P. (2013). Enhancement of aerosol characterization using synergy of lidar and sun-photometer coincident observations: the garrlic algorithm. Atmospheric Measurement Techniques, 6(8), 2065-2088. 6, 59

Lyamani, H., Olmo, F., Alcántara, A., and Alados-Arboledas, L. (2006). Atmospheric aerosols during the 2003 heat wave in southeastern spain i: Spectral optical depth. Atmospheric Environment, 40(33), 6453-6464. 61

Lyamani, H., Olmo, F. J., and Alados-Arboledas, L. (2010). Physical and optical properties of aerosols over an urban location in spain: seasonal and diurnal variability. Atmospheric Chemistry and Physics, 10(1), 239-254. 61

Mallet, M., Dulac, F., Formenti, P., Nabat, P., Sciare, J., Roberts, G., Pelon, J., Ancellet, G., Tanré, D., Parol, F., et al. (2016). Overview of the chemistry-aerosol mediterranean experiment/aerosol direct radiative forcing on the mediterranean climate (charmex/adrimed) summer 2013 campaign. 5

Mateos, D., Sanchez-Lorenzo, A., Antón, M., Cachorro, V., Calbó, J., Costa, M. J., Torres, B., and Wild, M. (2014). Quantifying the respective roles of aerosols and clouds in the strong brightening since the early 2000s over the iberian peninsula. Journal of Geophysical Research: Atmospheres, 119(17), 10-382. 16, 17

Mazzola, M., Stone, R., Herber, A., Tomasi, C., Lupi, A., Vitale, V., Lanconelli, C., Toledano, C., Cachorro, V. E., O’Neill, N., et al. (2012). Evaluation of sun photometer capabilities for retrievals of aerosol optical depth at high latitudes: The polar-aod intercomparison campaigns. Atmospheric environment, 52, 4-17. 59

Michalsky, J. J. (1988). The astronomical almanac's algorithm for approximate solar position (1950-2050). Solar Energy, 40(3), 227 - 235. 41 


\section{BIBLIOGRAFÍA}

Mitchell, R. M., O'Brien, D. M., and Campbell, S. K. (2006). Characteristics and radiative impact of the aerosol generated by the canberra firestorm of january 2003. Journal of Geophysical Research: Atmospheres, 111(D2). 98

Myhre, G. (2009). Consistency Between Satellite-Derived and Modeled Estimates of the Direct Aerosol Effect. Science, 325, 187-190. 85

Myhre, G., Bellouin, N., Berglen, T. F., Berntsen, T. K., Boucher, O., Grini, A., Isaksen, I. S. A., Johnsrud, M., Mishchenko, M. I., Stordal, F., and Tanre, D. (2007). Comparison of the radiative properties and direct radiative effect of aerosols from a global aerosol model and remote sensing data over ocean. Tellus, 59B, 115-129. 97, 98

Myhre, G., Shindell, D., Bréon, F.-M., Collins, W., Fuglestvedt, J., Huang, J., Koch, D., Lamarque, J.-F., Lee, D., Mendoza, B., Nakajima, T., Robock, A., Stephens, G., Takemura, T., and Zhang, H. (2013). Anthropogenic and natural radiative forcing, pages 659-740. Cambridge University Press, Cambridge, UK. 58

Neher, I., Buchmann, T., Crewell, S., Evers-Dietze, B., Pfeilsticker, K., Pospichal, B., Schirrmeister, C., and Meilinger, S. (2017). Impact of atmospheric aerosols on photovoltaic energy production scenario for the sahel zone. Energy Procedia, 125, 170-179. 58

Ohneiser, K., Ansmann, A., Baars, H., Seifert, P., Barja, B., Jimenez, C., Radenz, M., Teisseire, A., Floutsi, A., Haarig, M., Foth, A., Chudnovsky, A., Engelmann, R., Zamorano, F., Bühl, J., and Wandinger, U. (2020). Smoke of extreme australian bushfires observed in the stratosphere over punta arenas, chile, in january 2020: optical thickness, lidar ratios, and depolarization ratios at 355 and $532 \mathrm{~nm}$. Atmospheric Chemistry and Physics, 20(13), 8003-8015. 86, 91

OÑeill, N. T., Eck, T. F., Smirnov, A., Holben, B. N., and Thulasiraman, S. (2003). Spectral discrimination of coarse and fine mode optical depth. Journal of Geophysical Research, 108(D17), 4559. 89

O’Neill, N. T., Dubovik, O., and Eck, T. F. (2001). Modified ångström exponent for the characterization of submicrometer aerosols. Appl. Opt., 40(15), 2368-2375. 41

Pedregosa, F., Varoquaux, G., Gramfort, A., Michel, V., Thirion, B., Grisel, O., Blondel, M., Prettenhofer, P., Weiss, R., Dubourg, V., Vanderplas, J., Passos, A., Cournapeau, D., Brucher, M., Perrot, M., and Duchesnay, E. (2011). Scikit-learn: Machine learning in Python. Journal of Machine Learning Research, 12, 2825-2830. 52 
Pérez-Ramírez, D., Ruiz, B., Aceituno, J., Olmo, F., and Alados-Arboledas, L. (2008). Application of sun/star photometry to derive the aerosol optical depth. International Journal of Remote Sensing, 29(17-18), 5113-5132. 62

Pérez-Ramírez, D., Aceituno, J., Ruiz, B., Olmo, F., and Alados-Arboledas, L. (2008). Development and calibration of a star photometer to measure the aerosol optical depth: Smoke observations at a high mountain site. Atmospheric Environment, 42(11), 2733-2738. 59. 62

Pérez-Ramírez, D., Lyamani, H., Olmo, F. J., Whiteman, D. N., and Alados-Arboledas, L. (2012). Columnar aerosol properties from sun-and-star photometry: statistical comparisons and day-to-night dynamic. Atmospheric Chemistry and Physics, 12(20), 9719-9738. 61,63

Pérez-Ramírez, D., Lyamani, H., Smirnov, A., O’Neill, N., Veselovskii, I., Whiteman, D., Olmo, F., and Alados-Arboledas, L. (2016). Statistical study of day and night hourly patterns of columnar aerosol properties using sun and star photometry. In Remote Sensing of Clouds and the Atmosphere XXI, volume 10001, page 100010K. International Society for Optics and Photonics. 61

Petäjä, T., Mauldin Iii, R., Kosciuch, E., McGrath, J., Nieminen, T., Paasonen, P., Boy, M., Adamov, A., Kotiaho, T., and Kulmala, M. (2009). Sulfuric acid and oh concentrations in a boreal forest site. Atmospheric Chemistry \& Physics, 9(19). 59

Peterson, D. A., Campbell, J. R., Hyer, E. J., Fromm, M. D., Kablick, G. P., Cossuth, J. H., and DeLand, M. T. (2018). Wildfire-driven thunderstorms cause a volcano-like stratospheric injection of smoke. NPJ climate and atmospheric science, 1, 1-8. 91

Pérez-Ramírez, D., Lyamani, H., Olmo, F., and Alados-Arboledas, L. (2011). Improvements in star photometry for aerosol characterizations. Journal of Aerosol Science, 42(10), 737 $-745.63$

Ramanathan, V., Cess, R. D., Harrison, E. F., Minnis, P., Barkstrom, B. R., Ahmad, E., and Hartmann, D. (1989). Cloud-radiative forcing and climate: Results from the earth radiation budget experiment. Science, 243(4887), 57-63. 59

Ranjbar, K., OÑeill, N., Lutsch, E., McCullough, E., Aboel Fetouh, Y., Xian, P., Strong, K., Fioletov, V., Lesins, G., and Abboud, I. (2019). Extreme smoke event over the high arctic. Atmospheric Environment, 218, 117002. 85 


\section{BIBLIOGRAFÍA}

Ravelo-Pérez, L. M., Rodríguez, S., Galindo, L., García, M. I., Alastuey, A., and LópezSolano, J. (2016). Soluble iron dust export in the high altitude saharan air layer. Atmospheric Environment, 133, 49-59. 58

Reid, J. S., Koppmann, R., Eck, T. F., and Eleuterio, D. P. (2005). A review of biomass burning emissions part ii: intensive physical properties of biomass burning particles. Atmospheric Chemistry and Physics, 5(3), 799-825. 85, 98

Remer, L. A., Gassó, S., Hegg, D. A., Kaufman, Y. J., and Holben, B. N. (1997). Urban/industrial aerosol: Ground-based sun/sky radiometer and airborne in situ measurements. Journal of Geophysical Research: Atmospheres, 102(D14), 16849-16859. 59

Ritter, C., Burgos, M. A., Böckmann, C., Mateos, D., Lisok, J., Markowicz, K., Moroni, B., Cappelletti, D., Udisti, R., Maturilli, M., and Neuber, R. (2018). Microphysical properties and radiative impact of an intense biomass burning aerosol event measured over nyÅlesund, spitsbergen in july 2015. Tellus B: Chemical and Physical Meteorology, 70(1), 1-23. 85

Rodríguez, S., González, Y., Cuevas, E., Ramos, R., Romero, P. M., Abreu-Afonso, J., and Redondas, A. (2009). Atmospheric nanoparticle observations in the low free troposphere during upward orographic flows at izaña mountain observatory. Atmospheric Chemistry and Physics, 9(17), 6319-6335. 60, 61

Rodríguez, S., Alastuey, A., Alonso-Pérez, S., Querol, X., Cuevas, E., Abreu-Afonso, J., Viana, M., Pérez, N., Pandolfi, M., and de la Rosa, J. (2011). Transport of desert dust mixed with north african industrial pollutants in the subtropical saharan air layer. Atmospheric Chemistry and Physics, 11(13), 6663-6685. 61

Román, R., Antón, M., Valenzuela, A., Gil, J., Lyamani, H., De Miguel, A., Olmo, F., Bilbao, J., and Alados-Arboledas, L. (2013). Evaluation of the desert dust effects on global, direct and diffuse spectral ultraviolet irradiance. Tellus B: Chemical and Physical Meteorology, 65(1), 19578. 61

Román, R., Cazorla, A., Toledano, C., Olmo, F., Cachorro, V., de Frutos, A., and AladosArboledas, L. (2017a). Cloud cover detection combining high dynamic range sky images and ceilometer measurements. Atmospheric research, 196, 224-236. 17

Román, R., Torres, B., Fuertes, D., Cachorro, V. E., Dubovik, O., Toledano, C., Cazorla, A., Barreto, A., Bosch, J., Lapyonok, T., et al. (2017b). Remote sensing of lunar aureole 
with a sky camera: Adding information in the nocturnal retrieval of aerosol properties with grasp code. Remote Sensing of Environment, 196, 238-252. 17, 59

Román, R., Benavent-Oltra, J. A., Casquero-Vera, J. A., Lopatin, A., Cazorla, A., Lyamani, H., Denjean, C., Fuertes, D., Pérez-Ramírez, D., Torres, B., et al. (2018). Retrieval of aerosol profiles combining sunphotometer and ceilometer measurements in grasp code. Atmospheric Research, 204, 161-177. 6, 17, 59, 73

Román, R., González, R., Toledano, C., Barreto, A., Pérez-Ramírez, D., Benavent-Oltra, J. A., Olmo, F. J., Cachorro, V. E., Alados-Arboledas, L., and de Frutos, A. M. (2020). Correction of a lunar-irradiance model for aerosol optical depth retrieval and comparison with a star photometer. Atmospheric Measurement Techniques, Submitted. 12, 31, 42, 43, 50, 88

Saha, A., OÑeill, N. T., Eloranta, E., Stone, R. S., Eck, T. F., Zidane, S., Daou, D., Lupu, A., Lesins, G., Shiobara, M., and McArthur, L. J. B. (2010). Pan-arctic sunphotometry during the arctas-a campaign of april 2008. Geophysical Research Letters, 37(5). 85

Schafer, J. S., Eck, T. F., Holben, B. N., Artaxo, P., and Duarte, A. F. (2008). Characterization of the optical properties of atmospheric aerosols in amazônia from long-term aeronet monitoring (1993-1995 and 1999-2006). Journal of Geophysical Research: Atmospheres, 113(D4). 97

Schmid, B., Thorne, K. J., Demoulin, P., Peter, R., Mätzler, C., and Sekler, J. (1996). Comparison of modeled and empirical approaches for retrieving columnar water vapor from solar transmittance measurements in the 0.94-?m region. Journal of Geophysical Research: Atmospheres, 101(D5), 9345-9358. 42

Seidelmann, P. K., Archinal, B. A., A'hearn, M. F., Conrad, A., Consolmagno, G., Hestroffer, D., Hilton, J., Krasinsky, G., Neumann, G., Oberst, J., et al. (2007). Report of the iau/iag working group on cartographic coordinates and rotational elements: 2006. Celestial Mechanics and Dynamical Astronomy, 98(3), 155-180. 66

Shaw, G. (1976). Error analysis of multi-wavelength sun photometry. Pure and Applied Geophysics, 114, 1-14. 7, 9, 30, 40, 64

Shaw, G. E. (1983). Sun photometry. Bull. Am. Meteorol. Soc., 64, 4-10. 7, 30, 40, 64, 88

Shaw, G. E. (1988). Antarctic aerosols: A review. Reviews of Geophysics, 26(1), 89-112. 85 


\section{BIBLIOGRAFÍA}

Shindell, D. T., Lamarque, J.-F., Schulz, M., Flanner, M., Jiao, C., Chin, M., Young, P., Lee, Y. H., Rotstayn, L., Milly, G., et al. (2013). Radiative forcing in the accmip historical and future climate simulations. Atmospheric Chemistry and Physics, 13(6), 2939-2974. 3

Sinyuk, A., Holben, B. N., Eck, T. F., Giles, D. M., Slutsker, I., Korkin, S., Schafer, J. S., Smirnov, A., Sorokin, M., and Lyapustin, A. (2020). The aeronet version 3 aerosol retrieval algorithm, associated uncertainties and comparisons to version 2. Atmospheric Measurement Techniques, 13(6), 3375-3411. 89

Smirnov, A., Holben, B. N., Eck, T. F., Dubovik, O., and Slutsker, I. (2000). Cloud-Screening and Quality Control Algorithms for the AERONET Database. Remote Sens. Environ., 73, 337-349. 43, 45

Smirnov, A., Holben, B., Lyapustin, A., Slutsker, I., and Eck, T. (2004). Aeronet processing algorithms refinement. In AERONET Workshop, El Arenosillo, Spain, pages 10-14. 34

Speyerer, E., Wagner, R., Robinson, M., Licht, A., Thomas, P., Becker, K., Anderson, J., Brylow, S., Humm, D., and Tschimmel, M. (2016). Pre-flight and on-orbit geometric calibration of the lunar reconnaissance orbiter camera. Space Science Reviews, 200(1-4), 357-392. 66

Stein, A. F., Draxler, R. R., Rolph, G. D., Stunder, B. J. B., Cohen, M. D., and Ngan, F. (2016). NOAA's HYSPLIT Atmospheric Transport and Dispersion Modeling System. Bulletin of the American Meteorological Society, 96(12), 2059-2077. 89

Stevens, B. and Feingold, G. (2009). Untangling aerosol effects on clouds and precipitation in a buffered system. Nature, 461(7264), 607-613. 58

Stohl, A. and Sodemann, H. (2010). Characteristics of atmospheric transport into the antarctic troposphere. Journal of Geophysical Research: Atmospheres, 115(D2). 85

Sun, Y., Song, T., Tang, G., and Wang, Y. (2013). The vertical distribution of pm2. 5 and boundary-layer structure during summer haze in beijing. Atmospheric Environment, 74, 413-421. 59

Takamura, T., Nakajima, T., and SKYNET community group, . (2004). Overview of skynet and its activities. Optica Pura y Aplicada, 37, 3303 $\tilde{\mathrm{A}}^{-} \hat{\mathrm{A}}_{i} \hat{\mathrm{A}}_{2} \frac{1}{2} 3308.30$

Taylor, S., Greenwell, C., and Woolliams, E. (2018). D3: Lunar Photometer Calibration for Lunar Spectral Irradiance Measurements. Technical report. 72 
Tegen, I., Hollrig, P., Chin, M., Fung, I., Jacob, D., and Penner, J. (1997). Contribution of different aerosol species to the global aerosol extinction optical thickness: Estimates from model results. Journal of Geophysical Research: Atmospheres, 102(D20), 23895-23915. 2

Titos, G., Foyo-Moreno, I., Lyamani, H., Querol, X., Alastuey, A., and Alados-Arboledas, L. (2012). Optical properties and chemical composition of aerosol particles at an urban location: An estimation of the aerosol mass scattering and absorption efficiencies. Journal of Geophysical Research: Atmospheres, 117(D4). 61

Toledano, C. (2005). Climatología de los aerosoles mediante la caracterización de propiedades ópticas y masas de aire en la estación. ${ }^{E l}$ Arenosillo"de la red AERONET. Ph.D. thesis. 2, 129

Toledano, C., Cachorro, V. E., Berjon, A., de Frutos, A. M., Sorribas, M., de la Morena, B. A., and Goloub, P. (2007). Aerosol optical depth and Angstrom exponent climatology at El Arenosillo AERONET site (Huelva, Spain). Quarterly Journal of the Royal Meteorological Society, 133, 795-807. 16, 94

Toledano, C., Cachorro, V., Berjón, A., de Frutos, A., Fuertes, D., González, R., Torres, B., Rodrigo, R., Bennouna, Y., Martin, L., et al. (2011). Rima-aeronet network: long term monitoring of aerosol properties. Opt. Pura Apl, 44, 629-633. 16

Toledano, C., González, R., Fuertes, D., Cuevas, E., Eck, T. F., Kazadzis, S., Kouremeti, N., Gröbner, J., Goloub, P., Blarel, L., Román, R., Barreto, A., Berjón, A., Holben, B. N., and Cachorro, V. E. (2018). Assessment of sun photometer langley calibration at the high-elevation sites mauna loa and izaña. Atmospheric Chemistry and Physics, 18(19), 14555-14567. 15, 25, 30, 32, 41, 46, 61, 64, 67

Toledano, C., Torres, B., Velasco-Merino, C., Althausen, D., Groß, S., Wiegner, M., Weinzierl, B., Gasteiger, J., Ansmann, A., González, R., Mateos, D., Farrel, D., Müller, T., Haarig, M., and Cachorro, V. E. (2019). Sun photometer retrievals of saharan dust properties over barbados during saltrace. Atmospheric Chemistry and Physics, 19(23), 14571-14583. 89

Tomasi, C., Vitale, V., Lupi, A., Di Carmine, C., Campanelli, M., Herber, A., Treffeisen, R., Stone, R. S., Andrews, E., Sharma, S., Radionov, V., von Hoyningen-Huene, W., Stebel, K., Hansen, G. H., Myhre, C. L., Wehrli, C., Aaltonen, V., Lihavainen, H., Virkkula, A., Hillamo, R., Ström, J., Toledano, C., Cachorro, V. E., Ortiz, P., de Frutos, A. M., Blindheim, S., Frioud, M., Gausa, M., Zielinski, T., Petelski, T., and Yamanouchi, T. (2007). 


\section{BIBLIOGRAFÍA}

Aerosols in polar regions: A historical overview based on optical depth and in situ observations. Journal of Geophysical Research: Atmospheres, 112(D16). 85

Tomasi, C., Kokhanovsky, A. A., Lupi, A., Ritter, C., Smirnov, A., OÑeill, N. T., Stone, R. S., Holben, B. N., Nyeki, S., Wehrli, C., Stohl, A., Mazzola, M., Lanconelli, C., Vitale, V., Stebel, K., Aaltonen, V., de Leeuw, G., Rodriguez, E., Herber, A. B., Radionov, V. F., Zielinski, T., Petelski, T., Sakerin, S. M., Kabanov, D. M., Xue, Y., Mei, L., Istomina, L., Wagener, R., McArthur, B., Sobolewski, P. S., Kivi, R., Courcoux, Y., Larouche, P., Broccardo, S., and Piketh, S. J. (2015). Aerosol remote sensing in polar regions. EarthScience Reviews, 140, 108 - 157. 94

Torres, B., Dubovik, O., Toledano, C., Berjon, A., Cachorro, V. E., Lapyonok, T., Litvinov, P., and Goloub, P. (2014). Sensitivity of aerosol retrieval to geometrical configuration of ground-based sun/sky radiometer observations. Atmospheric Chemistry and Physics, 14, 847-875. 16

Torres, B., Dubovik, O., Fuertes, D., Schuster, G., Cachorro, V. E., Lapyonok, T., Goloub, P., Blarel, L., Barreto, A., Mallet, M., Toledano, C., and Tanré, D. (2017). Advanced characterisation of aerosol size properties from measurements of spectral optical depth using the grasp algorithm. Atmospheric Measurement Techniques, 10(10), 3743-3781. 53, 59

Torres, O. (2019). Omps-npp $12 \mathrm{~nm}$ aerosol index swath orbital v2. Greenbelt, MD, USA, Goddard Earth Sciences Data and Information Services Center (GES DISC), doi, 10. 89

Turner, J., Lu, H., White, I., King, J. C., Phillips, T., Hosking, J. S., Bracegirdle, T. J., Marshall, G. J., Mulvaney, R., and Deb, P. (2016). Absence of 21 st century warming on antarctic peninsula consistent with natural variability. Nature, 535, 411-415. 85

Twomey, S. (1977). The influence of pollution on the shortwave albedo of clouds. Journal of the atmospheric sciences, 34(7), 1149-1152. 4,58

Uchiyama, A., Shiobara, M., Kobayashi, H., Matsunaga, T., Yamazaki, A., Inei, K., Kawai, K., and Watanabe, Y. (2019). Nocturnal aerosol optical depth measurements with modified sky radiometer pom-02 using the moon as a light source. Atmospheric Measurement Techniques, 12(12), 6465-6488. 9, 13, 69

Valenzuela, A., Olmo, F., Lyamani, H., Antón, M., Quirantes, A., and Alados-Arboledas, L. (2012). Classification of aerosol radiative properties during african desert dust intrusions 
over southeastern spain by sector origins and cluster analysis. Journal of Geophysical Research: Atmospheres, 117(D6). 61

van der A, R. J., Allaart, M. A. F., and Eskes, H. J. (2010). Multi sensor reanalysis of total ozone. Atmospheric Chemistry and Physics, 10(22), 11277-11294. 39

Vergaz, R., Cachorro, V. E., de Frutos, A. M., Vilaplana, J. M., and de la Morena, B. A. (2005). Columnar characteristics of aerosols in the maritime area of the Cadiz Gulf (Spain). International Journal of Climatology, 25, 1793-1804. 41

Viticchie, B., Wagner, S., Hewison, T., Stone, T., Nain, J., Gutierrez, R., Muller, J., and Hanson, C. (2013). Lunar calibration of msg/seviri solar channels. In Proceedings of the EUMETSAT Meteorological Satellite Conference, Vienna, Austria, pages 16-20. 9, 60, 69

Voskresenskii, A. I. (1968). Condensation nuclei in the mirny region (in russian). Tr. Soy. Antarkt. Eksped., 38, 194-198. 85

Wehrli, C. (1985). Wrc reference spectrum. PMOD Publication, 615, 28. 43, 65, 67, 69

Wehrli, C. (2000). Calibration of filter radiometers for determination of atmospheric optical depth. Metrologia, 37, 419-422. 30

Wehrli, C. J. (2008). Remote Sensing of Aerosol Optical Depth in a global surface network. Ph.D. thesis, ETH ZURICH. 43

Weller, R., Minikin, A., Petzold, A., Wagenbach, D., and König-Langlo, G. (2013). Characterization of long-term and seasonal variations of black carbon (bc) concentrations at neumayer, antarctica. Atmospheric Chemistry and Physics, 13(3), 1579-1590. 85

Willeke, K. and Baron, P. A. (1993). Aerosol measurement: Principles. Techniques and Applications, VNR. 1

Winker, D. M., Vaughan, M. A., Omar, A., Hu, Y., Powell, K. A., Liu, Z., Hunt, W. H., and Young, S. A. (2009). Overview of the CALIPSO Mission and CALIOP Data Processing Algorithms. Journal of Atmospheric and Oceanic Technology, 26(11), 2310-2323. 89

WMO (2005). WMO/GAW Experts Workshop on a Global Surface-based Network for Long Term Observations of Column Aerosol Optical Properties. GAW Report 162, WMO/TDNo 1287, Davos 2004, edited by: Baltensperger, U., Barries, L., and Wehrli, C.,. 28, 47 , 48,130 
WMO (2014). Commission for Instruments and Methods of Observation (WMO-No. 1138)

Sixteenth session: abridged final report with resolutions and recommendations. 61

Zielinski, T., Bolzacchini, E., Cataldi, M., Ferrero, L., Graß1, S., Hansen, G., Mateos, D., Mazzola, M., Neuber, R., Pakszys, P., and et al. (2020). Study of chemical and optical properties of biomass burning aerosols during long-range transport events toward the arctic in summer 2017. Atmosphere, 11(1), 84. 85 


\section{Índice de figuras}

1.1 Forma típica de la distribución de tamaños de los aerosoles, con los tres modos y los mecanismos de formación y eliminación en la atmósfera (Toledano.

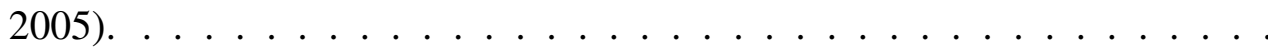

1.2 Transporte de los aerosoles por todo el planeta Tierra. La imagen ha sido obtenida de la simu- lación que NASA Goddard's Global Modeling and Assimilation Office realizó para el periodo de tiempo comprendido entre agosto de 2006 y agosto de 2007(https://svs.gsfc.nasa.gov/cgibin/details.cgi?aid=30017). En este caso se ve el resultado de la simulación para el 27 de enero de 2007. Los colores corresponden a: desértico (rojo), sal marina (azul), polución antropogénica y orgánica (verde), y sulfatos (blanco). . . . . . . . . . . . . . . . . .

1.3 Forzamiento radiativo del clima terrestre, fuente de la imagenIPCC Fifth Assessment Report (AR5) [Intergovernmental Panel on Climate Change (IPCC), 2013]

2.1 Ubicación de cada una de las estaciones de medida pertenecientes a la red AERONET. Imagen obtenida de la propia página web de la red AERONET (https://aeronet.gsfc.nasa.gov/cgi-bin/site_info) . .

2.2 Ubicación de las estaciones AERONET del GOA-UVa, de Norte a Sur se ven las estaciones de Ny-Ålesund (Noruega), Andenes (Noruega), Palencia, Valladolid, Izaña, Teide, Camagüey (Cuba) y Marambio (Antártida, Argentina) 18

2.3 Esquema de cada uno de los elementos que componen el CIMEL CE318. En la imagen se puede ver en la parte izquierda la cabeza sensora montada en el robot seguidor. En la parte derecha se puede ver la rueda de filtros que está instalada en la cabeza y la caja de control del fotometro. Imagen obtenida de Guirado-Fuentes (2015) . . . . . . . . . . . . . . . . . . . . . . . 


\section{ÍNDICE DE FIGURAS}

2.4 Geometrías de cada una de las medidas de radiancia de cielo que hace el Cimel . En la parte inferior se muestra un esquema de la geometría. La primera representa un almucantar, la segunda un plano principal y la tercera un híbrido. En la parte superior se muestra en puntos rojos los ángulos en los que se mide en cada geometría. Para estos ejemplos se ha usado la cámara todo cielo instalada en la Facultad de Ciencias de la Universidad de Valladolid con ángulos solares cenitales de $69.51^{\circ}, 70.38^{\circ}$ y $28.25^{\circ}$ respectivamente. . .

2.5 Diagrama de la arquitectura de CÆLIS. Las flechas indican dónde se inicia la acción (el flujo de datos es siempre bidireccional). Figura obtenida de Fuertes et al. (2018) . . . . . . . . . . . . . . . . . . . . . . . . . . . .

2.6 Módulo de visualización de CÆLIS que permite acceder a los datos procesados por el sistema para detectar anomalías en las medidas de los distintos instrumentos. Figura obtenida de www. caelis.uva.es . . . . . . .

3.1 Flux diagram of the retrieval of necessary data to be used by the AOD al-

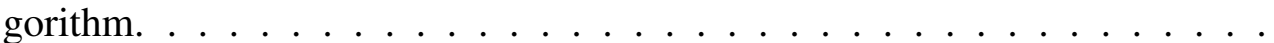

3.2 Flux diagram of the AOD computation in CÆLIS. . . . . . . . . . .

3.3 (a) CÆLIS atmospheric pressure as a function of AERONET atmospheric pressure for different stations. (b) Frequency histogram of the atmospheric pressure differences between CÆLIS and AERONET databases for all stations. 37

3.4 Climatology of $\mathrm{NO}_{2}$ (Dobson units $\times 10^{3}$ ) for the month of August. Data obtained from OMI version 3 (OMNO2d gridded, level 3) data between 2005 and 2017

3.5 Climatology of $\mathrm{O}_{3}$ (Dobson units) for the month of May. Data obtained from the ulti-sensor-reanalysis from GOME-2, OMI and SCIAMACHY sensors between 1978 and 2008.

3.6 Frequency histogram of the differences between CÆLIS and AERONET databases for (a) $\mathrm{NO}_{2}$ climatology and (b) $\mathrm{O}_{3}$ climatology. Data in Dobson units $(\mathrm{DU}) . \ldots \ldots \ldots \ldots \ldots \ldots$

3.7 Differences in AOD (AERONET-CÆLIS) as a function of air mass for several channels. The red lines indicate the maximum and minimum of the differences. The orange lines indicate the boundaries of the U95 criterion of the WMO (2005) . . . . . . . . . . . . . . . . . . . .

3.8 (a) Day and nighttime AOD retrievals at different sites and Moon phases.

(b) Same for Ångström exponent (440-870nm). The black line indicates the Moon phase angle (MPA, right axis). 
3.9 Confusion matrix for comparison of the cloud screening performed by AERONET and CÆLIS. Absolute number of cases and relative values (in percent) are given. . . . . . . . . . . . . . . . . .

3.10 a) Differences between AOD from Gain calibration and the reference values at night as function of Moon Phase Angle (MPA) for different wavelengths; b) RIMO Correction Factor (RCF) against MPA for different wavelengths; c) Fitted RCF and \pm its propagated uncertainty vs. MPA for different wavelengths (340 $\mathrm{nm}$ values are not shown because they are out of the axis limits); and d) Fitted RCF and \pm its propagated uncertainty (error bars) against the nominal wavelength of each CE318-T channel, for different MPA values. . . . . . .

3.11 Aerosol optical depth (AOD) values from Sun, Moon and star photometer at Granada (Spain) from the first to third Moon quarter in July 2016. Bottom panel at right shows the Ångström Exponent (AE) calculated with the wavelengths of 440, 500 and 675 and $870 \mathrm{~nm}(436,500,670$ and $880 \mathrm{~nm}$ for star photometer). Moon phase angle (MPA) is represented with a black line in each panel. . . . . . . . . . . . . . . . .

3.12 Aerosol optical depth (AOD) and Ångström Exponent (AE) from Moon photometer versus the AOD and AE from star photometer for 2016-2017 period and for different wavelengths. Colour legend represents the relative density of data points. Black lines indicate linear fit to the data. . . . . . . . . . . .

3.13 Frequency of the aerosol optical depth (AOD) differences between the Moon and star photometers for different wavelengths. Bottom-right panel shows the frequency of these differences for the Ångström Exponent (AE) in the

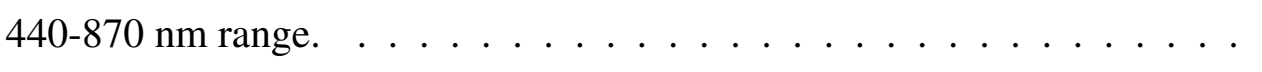

3.14 Aerosol optical depth (AOD) differences between the Moon and star photometers as a function of Moon phase angle (MPA) for different wavelengths. Bottom-right panel shows these differences for Ångström Exponent (AE) in the 440-870 $\mathrm{nm}$ range. Black circles represent the median of all differences in a $\pm 5^{\circ}$ MPA interval, while error bars indicate \pm standard deviation of the data in the same interval. . . . . . . . . . . . . . . . .

3.15 Location of the Marambio station (Antarctica) and Tumbarumba AERONET station (Australia)

3.16 (a) Aerosol optical depth (AOD) for different wavelengths and Ångström exponent (AE) at Marambio on 5-12th January 2020. (b) Fine and coarse mode aerosol optical depth at $500 \mathrm{~nm}$ and the fine mode fraction at Marambio on 5-12th January 2020. . . . . . . . . . . . . . . . . . . . . 


\section{ÍNDICE DE FIGURAS}

3.17 Vertical profiles of total attenuated backscatter at $532 \mathrm{~nm}$ from CALIOP/CALIPSO overpasses. The profiles are shown for six different overpasses from 7th to 10th January 2020. The highest aerosol layers close to Marambio location are marked with a red circle. . . . . . . . . . . . . . .

3.18 Ensemble HYSPLIT 10-days back-trajectories computed from Marambio at $13 \mathrm{~km}$ asl from 6 th to $11 \mathrm{st}$ January $2020 \ldots \ldots$. . . . . . . . . . .

3.19 Aerosol Index PyroCumuloNimbus (AI-PCN) maps over Pacific ocean for 10 different days during the smoke transport from Australia to Marambio station. These maps have been extracted from NASA's Earth Observing System Data and Information System (EOSDIS) worldview tool (https: //worldview.earthdata.nasa.gov) . . . . . . . . . . . .

3.20 Daily mean of Ångström exponent (AE) vs. aerosol optical depth (AOD) at $500 \mathrm{~nm}$ at Marambio (until April 2020). Colorbar indicates the date of each data point highlighting the analyzed days of the event. . . . . . . . . . . . .

3.21 Volume particle size distribution over Marambio, Antarctica, on 9th and 10th January 2020 (daily averages), as well as the mean of the daily averaged size distribution over Tumbarumba, Australia, for the period 25-30 December 2019. Color shaded areas represent \pm 1 standard deviation. . . . . . . . . .

3.22 Single scattering albedo (SSA) as a function of wavelength over Marambio, Antarctica, on 9th and 10th January 2020 (daily averages), as well as the mean of the daily averaged SSA over Tumbarumba, Australia, for the period 25-30 December 2019. Color shaded areas represent \pm 1 standard deviation.

3.23 Absorption Ångström exponent (AAE) as a function of: (a) Fine Mode Fraction of the AOD (500 nm); and (b) Extinction Ångström exponent (AE) derived in the range 440-870 $\mathrm{nm}$. Data points are inversion data (almucantar and hybrid sky scans) for Marambio, Antarctica, on 9th and 10th January 2020, and Tumbarumba, Australia, for the period 25-30 December 2019. . . 


\section{Índice de tablas}

3.1 List of Sun photometers used during the validation study. The analyzed period for all sites spans from 01 January 2016 to 31 December 2017 . . . .

3.2 Fitting coefficients of the RIMO Correction Factor (equation (3.17), the number of used data $(N)$, and median $(M d)$ and standard deviation $(S D)$ of the residuals in RIMO Correction Factor (RCF) and aerosol optical depth (AOD) for different photometer wavelengths.The fitting values at $340 \mathrm{~nm}$ has been obtained without MPA absolute values above $55^{\circ}$.

3.3 Statistical estimators of the differences between the aerosol optical depth (AOD) from Moon and star photometers for different wavelengths and periods. $N$ is the number of used data; $M, M d$ and $S D$ represents the mean, median and standard deviation of these differences, respectively; $y_{0}, s l p$ and $r$ are the y-intercept, slope and correlation coefficient from the linear fit between the AOD from Moon and star photometers. These estimators are also presented for the Ångström Exponent (AE) in the 440-870 nm range. . 
